\title{
A new compositionally-based
}

\author{
thermal conductivity model
}

\author{
for plutonic rocks
}

Thesis submitted in accordance with the requirements of the University of Adelaide for an Honours Degree in Geophysics

Sam Jennings

November 2017

THE UNIVERSITY of ADELAIDE 


\title{
A NEW COMPOSITIONALLY-BASED THERMAL CONDUCTIVITY MODEL FOR PLUTONIC ROCKS
}

\section{A NEW THERMAL CONDUCTIVITY MODEL}

\begin{abstract}
Thermal conductivity is a physical parameter crucial to accurately estimating and understanding temperature related processes within the lithosphere. Direct measurements however are not always practical and so recent research has turned to indirect estimates, often developing regionally-specific models from non-causal physical properties. In this study I report on 340 new thermal conductivity measurements of (mostly) plutonic rocks using an optical scanning device, coupled with major element geochemistry and modal mineralogy to produce broadly applicable empirical relationships between composition and thermal conductivity. Predictive models for thermal conductivity are developed using (in order of decreasing accuracy) major oxide composition, CIPW norms and estimated modal mineralogy. I find that $\mathrm{SiO}_{2}$ content is the dominant elementary control on thermal conductivity due not only to its relationship with quartz but also its relatively large abundance over the entire compositional range. The feldspars are the major control on thermal conductivity for both mineralogy based models, with particular emphasis on the transition from Na-rich albite to Ca-rich anorthite. Four common mixing models (arithmetic, geometric, squareroot and harmonic) are tested and, while the results are similar, the geometric model produces the best fit. The preferred model uses five commonly reported oxides $\left(\mathrm{SiO}_{2}\right.$, $\mathrm{Al}_{2} \mathrm{O}_{3}, \mathrm{FeO}, \mathrm{Na}_{2} \mathrm{O}$ and $\mathrm{K}_{2} \mathrm{O}$ ) plus loss on ignition to predict thermal conductivity across the entire compositional spectrum of plutonic rocks to within $0.27 \mathrm{~W} \mathrm{~m}^{-1} \mathrm{~K}^{-1}$. Since geochemistry cannot always be sampled directly, a comparison of thermal conductivity and oxide-based estimates of P-wave velocity and density reveal systematic trends across the compositional range. Relating thermal conductivity, via a direct compositional control, to these widely available surface measurements allows for a more universal predictive model of thermal conductivity than has been previously established.
\end{abstract}

\section{KEYWORDS}

Thermal conductivity, estimation, prediction, model, composition, chemistry, igneous, plutonic 


\section{TABLE OF CONTENTS}

Abstract.

Keywords.....

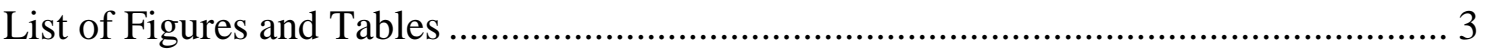

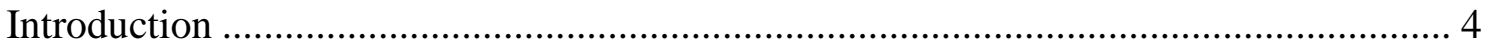

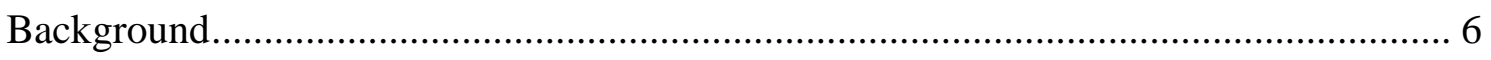

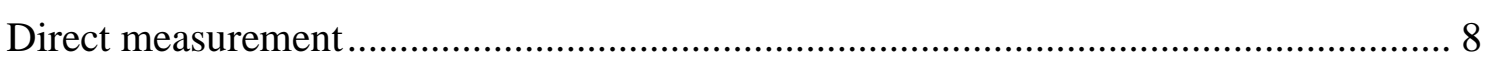

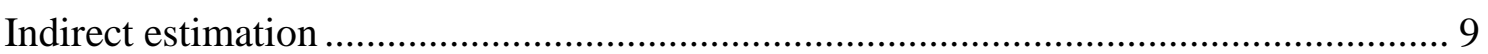

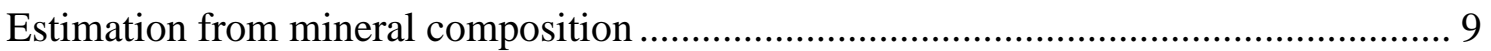

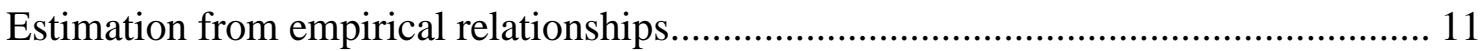

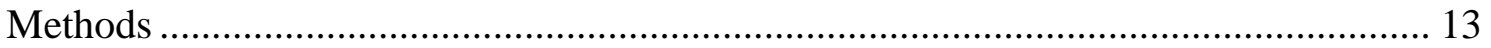

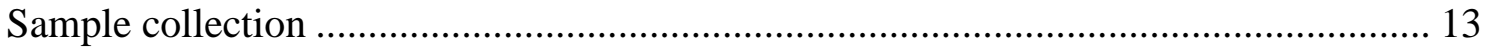

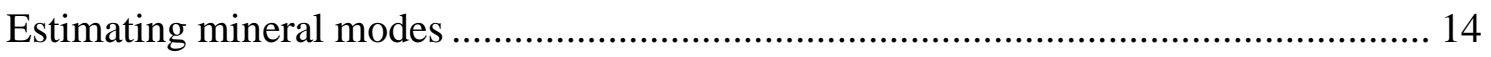

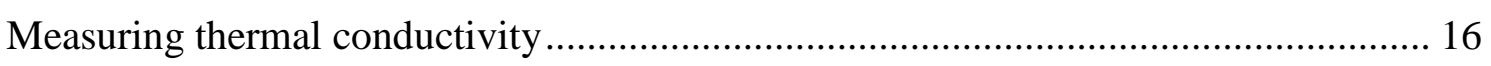

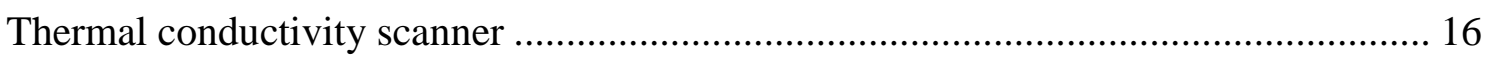

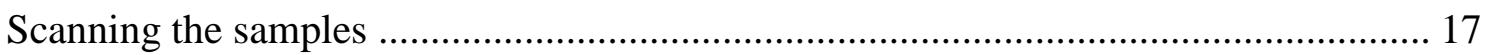

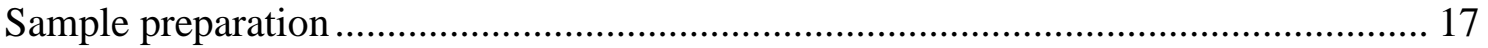

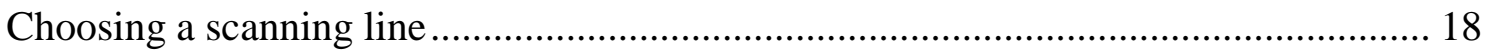

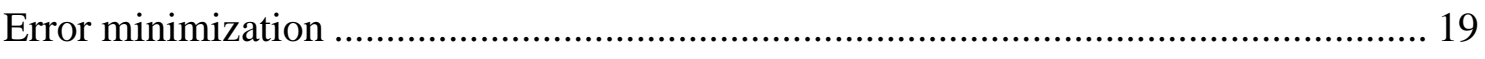

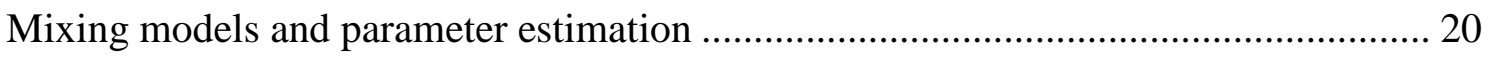

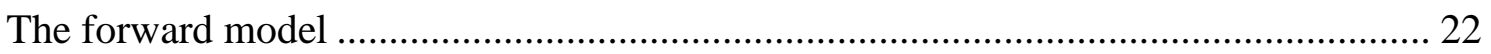

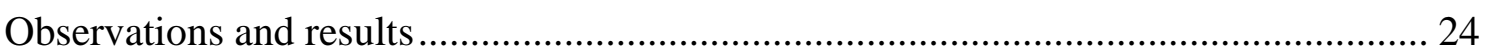

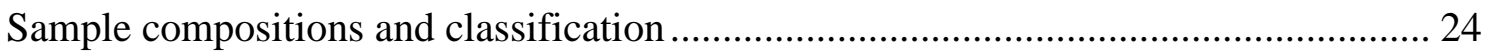

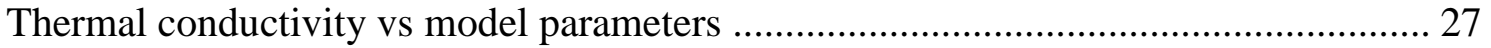

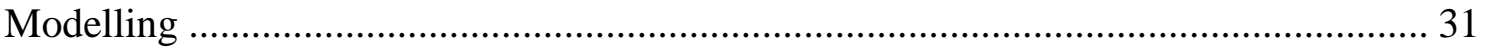

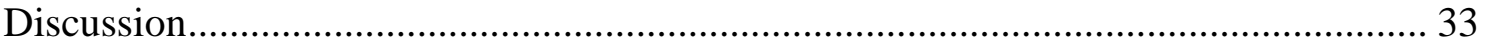

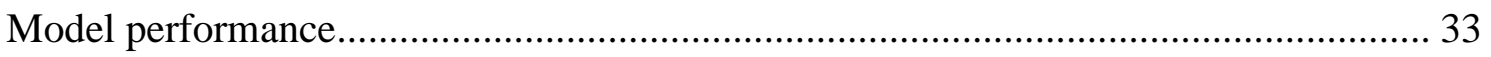

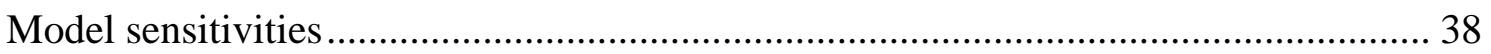

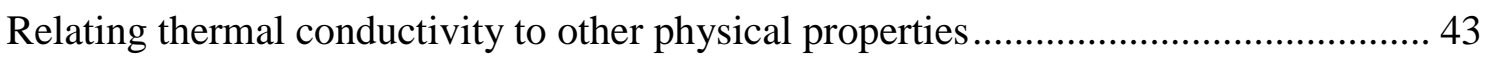

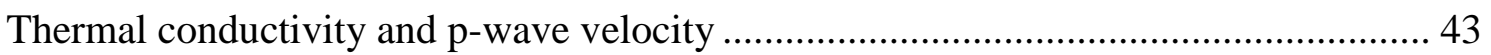

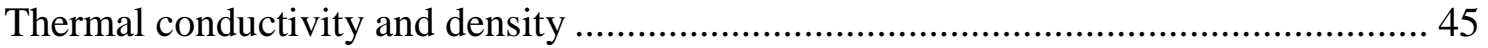

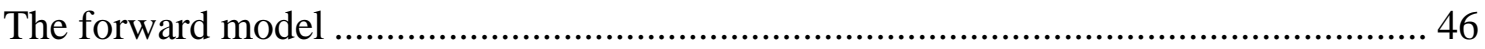

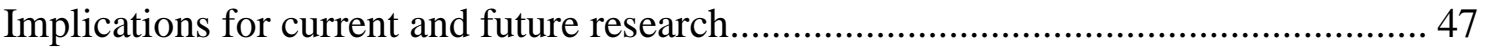

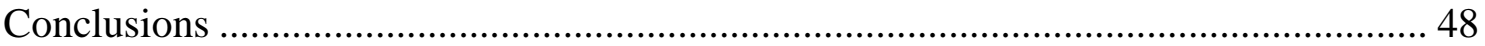




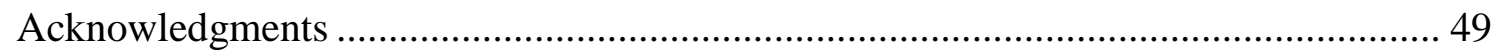

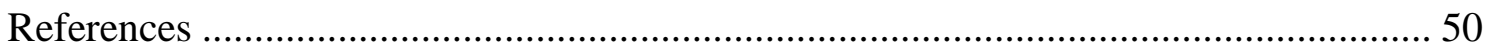

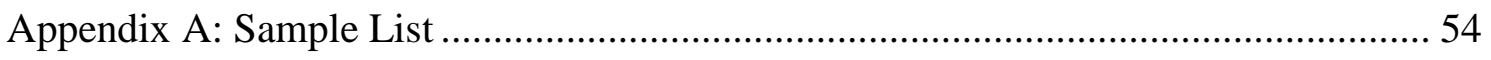

Appendix B: Whole Rock Geochemistry and CIPW Normative Mineralogy ............... 63

Appendix C: Extend methods: ImageJ and Trainable Weka Segmentation.................. 100 


\section{LIST OF FIGURES AND TABLES}

Figure 1 - Image segmentation and classification using the Trainable Weka

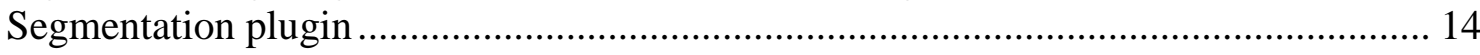

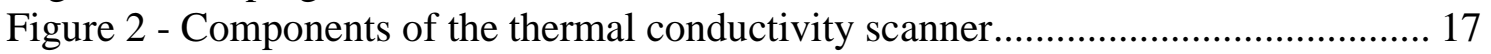

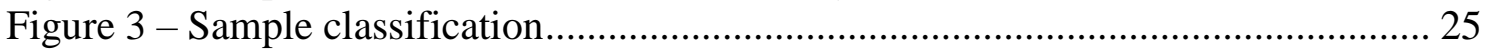

Figure 4 - Relationship between thermal conductivity and the major oxides ................ 28

Figure 5 - Relationship between thermal conductivity and estimated modal mineralogy

Figure 6 - Relationship between thermal conductivity and the calculated CIPW

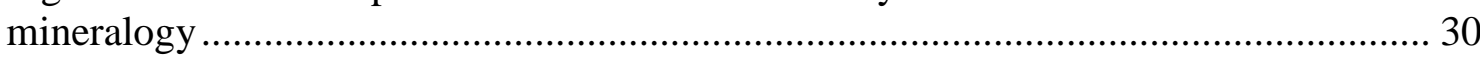

Figure 7 - Model residuals from the major oxide model using different mixing models

Figure 8 - Model coefficients and standard errors in linear space................................. 36

Figure 9 - Relationship between thermal conductivity and estimated p-wave

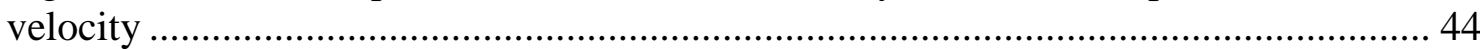

Figure 10 - Relationship between thermal conductivity and estimated density ............. 46

Table 1 - Laboratory derived mineral conductivities ................................................. 23

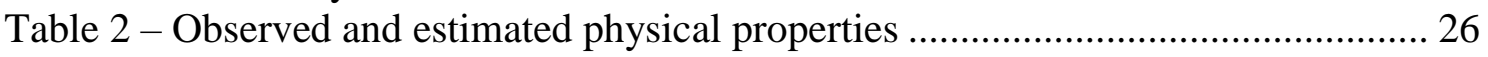

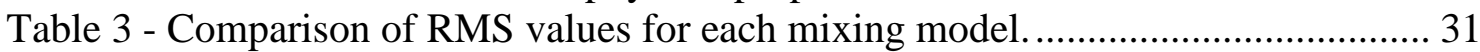

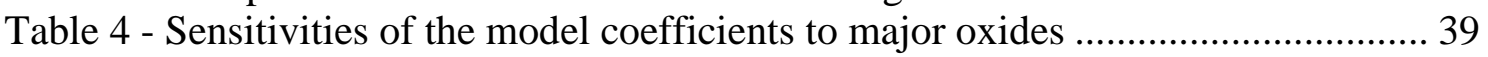

Table 5 - Sensitivities of the model coefficients to CIPW normative minerals ............. 40

Table 6 - Sensitivities of the model coefficients to modal minerals .............................. 42 


\section{INTRODUCTION}

Thermal conductivity is an inherent material property that characterizes the effectiveness of heat transfer as a result of temperature gradient and is a crucial aspect of heat flow modelling, particularly within the lithosphere. Accurate estimation of thermal conductivity benefits a wide range of geoscientific applications including tectonics, volcanology, geothermal exploration, heat production and environmental geophysics (Schön, 2015). For plutonic rocks, composition-especially the dominant mineral phase - is considered to be the main controlling factor of thermal conductivity (Clauser \& Huenges, 1995). Additional potential influences on thermal conductivity include temperature and pressure (Horai \& Susaki, 1989; Seipold, 1998; Vosteen \& Schellschmidt, 2003), porosity and pore fluid (Brigaud \& Vasseur, 1989; Y. Popov, Tertychnyi, Romushkevich, Korobkov, \& Pohl, 2003) and anisotropy (Davis, Chapman, Van Wagoner, \& Armstrong, 2007; Pribnow \& Umsonst, 1993).

Thermal conductivity can be measured directly in the laboratory on rock samples or drill core but the results do not always translate well to large scale settings (Clauser, 2011; Fuchs \& Förster, 2014). On top of this, direct measurements of conductivity and characterization of its spatial variability are often costly and time consuming (Sundberg, Back, Ericsson, \& Wrafter, 2009). Indirect estimation of thermal conductivity can be made using various mixing models (Clauser \& Huenges, 1995; Fuchs, Schütz, Förster, \& Förster, 2013) and an intimate knowledge of the mineralogy, pore fluid and laboratory derived values of mineral thermal conductivity (Clauser \& Huenges, 1995; Pribnow \& Umsonst, 1993; Vasseur, Brigaud, \& Demongodin, 1995). In situations where data is sparse or simply unobtainable, thermal conductivity can be estimated to 
varying degrees of accuracy by using empirical relationships with other petrophysical properties such as density, porosity and P-wave velocity (Esteban et al., 2015; Gu, Rühaak, Bär, \& Sass, 2017; Hartmann, Rath, \& Clauser, 2005; Mielke, Bär, \& Sass, 2017; Sundberg et al., 2009). The issue with empirical models is that most are based on observed relationships that can differ significantly between studies and therefore have little universal application (Fuchs \& Förster, 2014).

Previous attempts to establish such models are limited because they typically link thermal conductivity with other derivative physical properties. As these physical properties are not a direct control on thermal conductivity they suffer from significant non-uniqueness from region to region. This study focuses on establishing a relationship between thermal conductivity and major oxide composition. As a direct control, composition can be used to predict thermal conductivity without the added complexities and uncertainty in estimation from derived physical properties. A relationship with major oxide composition also has the added benefit of unlocking an entire new dataset for estimation of thermal conductivity.

I develop three new and effective models for estimating thermal conductivity from major oxide composition, CIPW normative mineralogy, and estimated modal mineralogy. To produce these models, I collected 340 new thermal conductivity measurements on plutonic rocks spanning a wide compositional range with measured compositions determined from previous studies. For samples without reported modal mineralogy, I explore the use of image processing and machine learning software to estimate modal proportions. The nature of these models will allow for computation of 
thermal conductivity from both local and global geochemical data. I will also show that this model can be used to establish relationships with other physical parameters such as density and p-wave velocity.

\section{BACKGROUND}

Thermal conductivity is the material property that controls the rate of heat flux through a medium. It is governed by Fourier's Law which defines the specific heat flow, $q$, as the product of thermal conductivity, $k$, and the temperature gradient $\partial T / \partial x$.

$$
q=-k \frac{\partial T}{\partial x}
$$

Equation (1) is simplified to its one-dimensional form as heat flow within the Earth can be assumed to be predominantly vertical (Clauser \& Huenges, 1995). This assumption typically holds true for plutonic and volcanic rocks which, to reasonable expectation, are isotropic due to random distribution and orientation of mineral constituents (Clauser, 2009). Sedimentary and metamorphic rock types can exhibit strongly anisotropic properties due to compositional layering and or preferred orientation of mineral fabrics. At the microscopic scale many minerals also display anisotropic properties, though the effect is minimal when orientations are randomly distributed such that the macroscopic properties of the rock are isotropic (Clauser \& Huenges, 1995).

A certain degree of variability is inherent in assigning thermal conductivity values to rocks owing to significant variations in both mineral compositions and textures (Schön, 2015). Emphasizing the point, Clauser (2011) states that "rock type is a rather poor 
descriptor of physical properties as it rarely characterizes the dominating factors for any given property”. In an earlier paper, these dominating factors are discussed statistically with regards to the four main rock groups; sedimentary, metamorphic, volcanic and plutonic (Clauser \& Huenges, 1995). For sedimentary rocks the main factors controlling conductivity are porosity and sediment type while the dominant factor for volcanic rocks is porosity alone. For metamorphic and plutonic rocks the dominant factor controlling thermal conductivity is the dominant mineral phase of the rock (Clauser \& Huenges, 1995). For metamorphic rocks the conductivity depends mostly on the abundance of quartz while feldspar content is the dominant control for plutonics (Clauser \& Huenges, 1995)

Other factors such as temperature, pressure and saturating fluid may also influence the thermal conductivity of rocks (Clauser, 2006; Clauser \& Huenges, 1995). It has long been known that thermal conductivity of rocks is dependent on temperature (Birch \& Clark, 1940) and many efforts have been made to model this relationship with reasonable success (Sass, Lachenbruch, Moses, \& Morgan, 1992; Seipold, 1998; Vosteen \& Schellschmidt, 2003). This relationship is due to a decrease in lattice conductivity with increasing temperature and, to a lesser extent, cracks resulting from thermal expansion (Clauser, 2006; Clauser \& Huenges, 1995). The effect of pressure on thermal conductivity is generally one that reflects an increase with pressure due to the closure of microcracks and decreasing porosity (Clauser, 2006; Horai \& Susaki, 1989). For porous rocks, thermal conductivity will also vary depending on the degree of porosity and on the nature of the pore fluid (Brigaud \& Vasseur, 1989). Due to the low 
thermal conductivity of most fluids, porous rocks will typically have lower conductivity than compositionally similar, non-porous rocks (Schön, 2015).

\section{Direct measurement}

A number of laboratory techniques are available to measure thermal conductivity of rock samples or drill core including the divided bar method (Chekhonin et al., 2012), needle probe (Von Herzen \& Maxwell, 1959), optical scanning (Y. A. Popov, Pribnow, Sass, Williams, \& Burkhardt, 1999) or laser flash (Blumm \& Lemarchand, 2002; Parker, Jenkins, Butler, \& Abbott, 1961). Since its inception, the optical scanning method has become commonplace owing to its high speed of operation, non-destructive means and ability to measure curved surfaces (Fuchs et al., 2013; Y. A. Popov et al., 1999). An added benefit is that, being a non-contact technique, no error arises from the effect of thermal resistance between the heating surface and sample surface (Hofmeister $\&$ Pertermann, 2008). For measurements at high temperature $\left(>500^{\circ} \mathrm{C}\right)$, non-contact methods also eliminate the effect of radiative transfer which is indistinguishable from lattice conductivity using contact methods (Hofmeister, 2007).

Typically, laboratory techniques tend to have a higher resolution than in situ estimations and for this reason can detect smaller scale variations in thermal conductivity (Y. A. Popov et al., 1999), however, laboratory measurements may not be representative of large scale trends (Clauser, 2011). As direct measurements are often restricted to a target formation, thermal conductivity for entire profiles are left to indirect determinations from other physical properties (Fuchs \& Förster, 2014). 


\section{Indirect estimation}

Indirect estimates of thermal conductivity are generally made when the cost or practicality in obtaining direct measurements becomes too great (Clauser, 2009; Sundberg et al., 2009). Methods for obtaining indirect estimations may be purely or semi-empirical or they may be well-defined physical models (Fuchs et al., 2013). One such method is to use mineralogical composition and laboratory-derived mineral thermal conductivity values to estimate bulk thermal conductivity.

\section{ESTIMATION FROM MINERAL COMPOSITION}

Calculating the effective conductivity of a rock sample from mineral composition is possible due to the fact that minerals typically have a much tighter constrained thermal conductivity value than that for any given rock type. Variations however still exist between separate studies into mineral conductivity mainly due to lattice imperfections in individual samples which can significantly decrease the thermal conductivity (Clauser, 2006). Various mixing models exist to calculate the effective thermal conductivity depending on the geometry of the components involved but only four will be presented here.

The parallel and series models are relatively straight forward and both represent bodies of layered media. The parallel model is used when heat flow is parallel to the layered surfaces and is best described by the commonly known weighted arithmetic mean (2) where $n_{i}$ is the volume fraction relative to the total volume and $k_{i}$ is the conductivity of the layer (Clauser, 2006). 


$$
k_{\text {ari }}=\sum n_{i} k_{i}
$$

As heat flow is almost always vertical within the earth (Clauser, 2009), real world applications of the parallel model are confined to situations where there exists some vertical contact between formations. Examples of this might include areas of faulting, igneous intrusions or tight folding. The series model describes a situation where heat flow is perpendicular to the layered surfaces and is analogous of a well hole drilled through a body of horizontally layered beds (Beardsmore \& Cull, 2001). In this model the mean conductivity of the body is best described by the harmonic mean (3) of the individual layers where all symbols are as in Equation 2.

$$
k_{\text {har }}=\left(\sum \frac{n_{i}}{k_{i}}\right)^{-1}
$$

The arithmetic and harmonic means represent the maximum and minimum values for conductivity estimates for a given body. In cases where the body consists of a number of randomly oriented and evenly distributed components of known conductivities, it is most common to use the geometric mean (5) or the square root mean (6) to determine the effective conductivity.

$$
\begin{gathered}
k_{\text {geo }}=\prod k_{i}^{n_{i}} \\
k_{S R M}=\left(\sum n_{i} \sqrt{k_{i}}\right)^{2}
\end{gathered}
$$


This situation is most representative of a rock sample consisting of several randomly oriented minerals of known conductivities. For rocks with significant pore space, the pore fluid can be added to the equation as a component in its own right.

\section{ESTIMATION FROM EMPIRICAL RELATIONSHIPS}

Numerous empirical models have been produced using well logs to predict thermal conductivity based on observed relationships with other physical properties, namely density and p-wave velocity. Thermal conductivity, density and p-wave velocity share a complex secondary relationship due to variable individual relationships with primary controls, composition and porosity (including cracks and fractures). In general thermal conductivity will decrease with porosity and maficity while p-wave velocity and density will decrease with porosity but increase with maficity to varying degrees (Schön, 2015).

Williams and Anderson (1990) developed a phonon conduction model using density, pwave and temperature data to predict thermal conductivity to within $\pm 15 \%$ in both isotropic and anisotropic crystalline rocks. This method however is restricted to situations in which all three physical properties are measured concurrently (Fuchs \& Förster, 2014). Hartmann et al. (2005) for a single borehole using only density and pwave velocity, managed to predict thermal conductivity in sedimentary sequences from laboratory data to within $0.2 \mathrm{~W} \mathrm{~m}^{-1} \mathrm{~K}^{-1}$ and from borehole data to within $0.3 \mathrm{~W} \mathrm{~m}^{-1} \mathrm{~K}^{-1}$. Despite reasonable results, their research has limited general applicability and is best suited to sandy shale units while failing to characterize conductivity in sandstone/carbonate settings. 
Investigation into a number of thermal properties for $\sim 700$ crystalline drill core samples showed no significant correlation (Kukkonen \& Peltoniemi, 1998) while a study of 179 dry and saturated sandstones (Esteban et al., 2015) managed to predict thermal conductivity using the model of Pimienta, Sarout, Esteban, and Piane (2014) which requires an overly simplified mineralogy. Using inclusion and defect models, Gegenhuber and Schoen (2012) show good correlation (Pearson's $r \quad 0.9$ ), particularly for high-quartz granitic rock types, between p-wave velocity and thermal conductivity yet do not provide a predictive model. More recently Mielke et al. (2017) manage to predict conductivity to within $0.5 \mathrm{~W} \mathrm{~m}^{-1} \mathrm{~K}^{-1}$ for porous sedimentary rocks but fail to define trend in rocks of little to no porosity.

Despite the abundance of research, inconsistent results between many of the studies may suggest that no generally valid linear relationship exists between thermal conductivity, p-wave velocity or density (Fuchs \& Förster, 2014). This inconsistency is the result of complex relationships between these three physical properties as outlined by Schön (2015). The complexities of these second order relationships suggest a need for correlation via a more convenient primary control such as major oxide composition. 


\section{METHODS}

\section{Sample collection}

A total of 331 plutonic, 9 volcanic, and 4 quartzite samples with previously measured major oxide compositions were selected for thermal conductivity measurement. The samples are sourced from a large number of igneous rock suites from locations throughout Australia and the world. Modal mineralogy was reported for 29 of the hand specimens and estimated using the method described below for the remaining 80 samples. CIPW norms were calculated for all samples using the methods outlined by Hollocher (2004). References, compositions, modal proportions, CIPW calculations, and photographs of each sample are included in the Appendix.

The primary aim in establishing the collection was acquiring enough samples to perform statistically significant regression analysis. Emphasis was placed on covering as much compositional range as possible and preference was given to rocks of phaneritic texture, minimal deformation/foliation and relatively homogeneous mineralogy. However, these restrictions were progressively loosened to supplement portions of the compositional spectrum with few samples. Samples with numerous and obvious fractures were rejected as these features may introduce non-compositional thermal conductivity variations into the conductivity measurements. It is possible to selectively avoid these features in the scanner software but this was judged on a case by case basis. Exotic mineral assemblages and heavily altered samples were also rejected for simplicity and relevance of the models. Minimum dimensions of $4 \times 2 \times 2 \mathrm{~cm}$ were required for accurate results from the conductivity scanner. 


\section{Estimating mineral modes}

Image $\mathrm{J}$ is an open source image processing and analysis software developed by the

United States National Institutes of Health (Schneider, Rasband, \& Eliceiri, 2012).

Many of the plugins and features are designed for medical imaging, but can be adapted

to Earth science applications. These features can be downloaded and installed as plugins

when needed or come pre-packaged in bundled distributions. A specialised scientific

distribution of ImageJ known as Fiji (Fiji Is Just ImageJ) (Schindelin et al., 2012) was

used along with the plugin Trainable Weka Segmentation (TWS) (Arganda-Carreras et

al., 2017) to calculate the modal mineralogy of carefully selected samples. The TWS

plugin utilizes a number of training features and machine learning algorithms to

produce pixel-based segmentation and classification of an image (Figure 1).

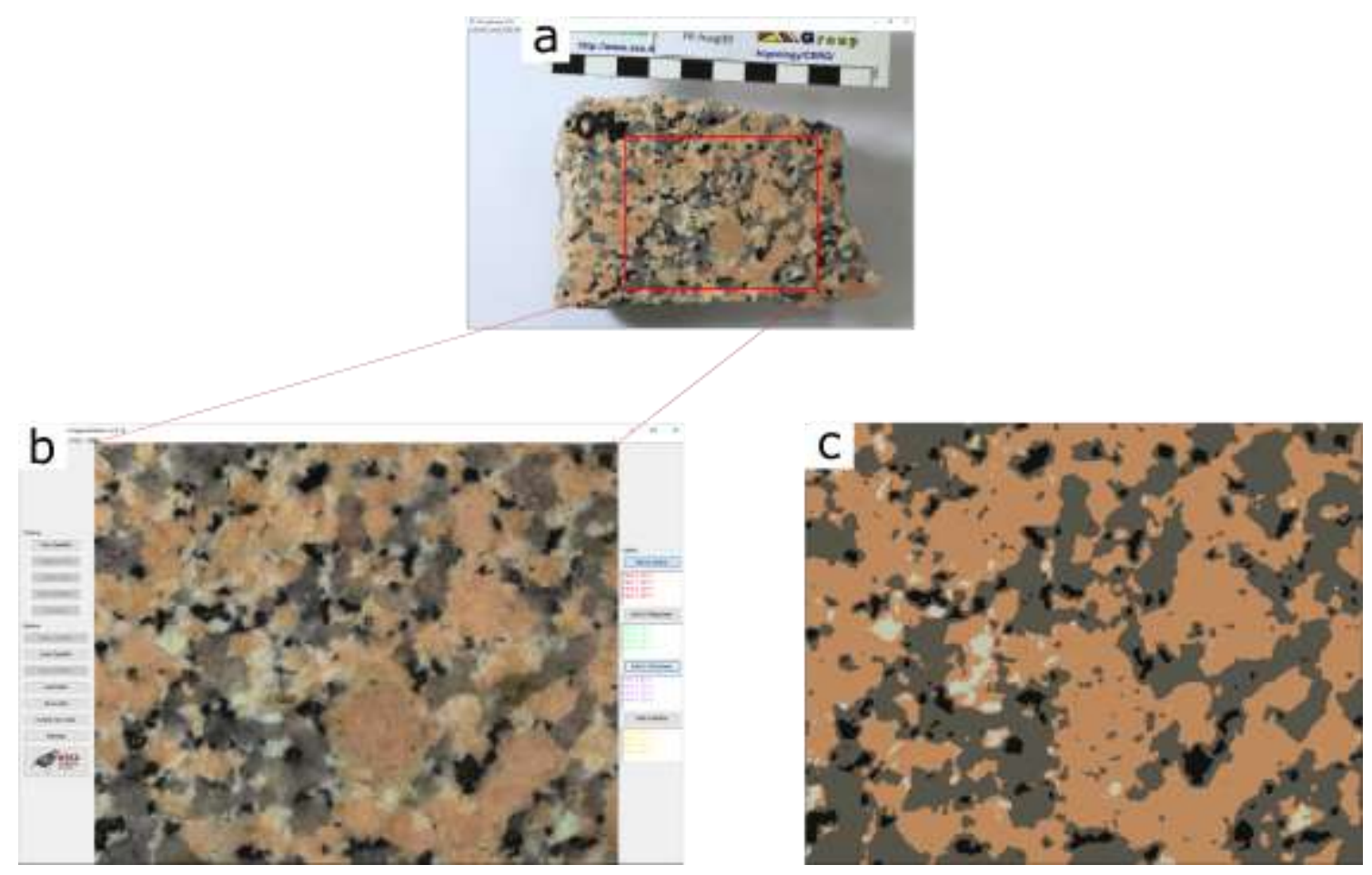

Figure 1 - Image segmentation and classification using the Trainable Weka Segmentation plugin.

A) Original samples photo with cropped area outlined, b) cropped image displayed within the TWS plugin, c) segmented image used to determine mineral modes. Modes were calculated as quartz (grey) $-\mathbf{4 1 . 3 5 \%}$, orthoclase (pink) $-\mathbf{5 0 . 9 9 \%}$, plagioclase (white) $-\mathbf{2 . 4 2 \%}$ and biotite (black) $5.24 \%$. 
A cropped area representative of the sample must first be selected (Figure 1a) to reduce image size and eliminate background pixels from the classification. The TWS plugin (Figure 1b) needs to be "trained" by assigning representative pixels (regions of interest) to specified classes relating to each mineral. A stack of feature images are created based on training features specified in the settings menu (these were left in the default setting). Using the feature images, the classifier algorithm FastRandomForest was used to segment and classify the image. From this classified image, area percentages are relatively straightforward to calculate for each mineral class (Figure 1c).

Estimating mineral modes using ImageJ and TWS requires knowledge of the mineralogy of each sample and the ability to visually distinguish individual minerals. TWS cannot identify minerals in its own right. Dark minerals such as biotite and hornblende are often too similar to be distinguished by the software and modal values for each are hard to obtain. To overcome this I classified both minerals together and divided the result proportional to the estimates from the original research. For example, a rock originally estimated by eye to contain $15 \%$ biotite and $5 \%$ hornblende is classified using TWS as having 10\% indistinguishable dark minerals. The resulting mineral modes from this situation would be $7.5 \%$ biotite and $2.5 \%$ hornblende. 


\section{Measuring thermal conductivity}

\section{THERMAL CONDUCTIVITY SCANNER}

Samples were scanned using the Thermal Conductivity Scanner (TCS) at the University of Adelaide on loan from Torrens Energy Ltd (Figure 2). The TCS is an optical scanning device developed by Prof. Dr. Yuri Popov and produced by TCS - Lippmann and Rauen. The TCS technology allows scanning of a planar or cylindrical surface using a mobile, focused and continuous heat source placed between two infrared temperature sensors (Figure 2c). The cold sensor records the initial temperature of the sample while the hot sensor records the excess temperature along the same plane after the heat source is applied.

Samples are lined up on the stage (Figure 2f) between two reference standards of known conductivity (Figure 2d). The bundled TCS software compares the excess temperature of the standards with the excess temperature of the unknown sample and calculates a thermal conductivity for the sample based on this information. This method works best when the thermal conductivity of the standards is as close as possible to the thermal conductivity of the unknown sample being measured. Using this method, thermal conductivity can be determined to within $3 \%$ over a range of 0.2 to $25 \mathrm{~W} \mathrm{~m}^{-1} \mathrm{~K}^{-1}$.

The TCS has a number of advantages over other methods of measuring thermal conductivity, primarily that it provides measurements through non-destructive means. It can also provide information on the spatial distribution of thermal conductivity in heterogeneous samples and there are only limited restrictions on the size, shape and quality of the samples being measured. 


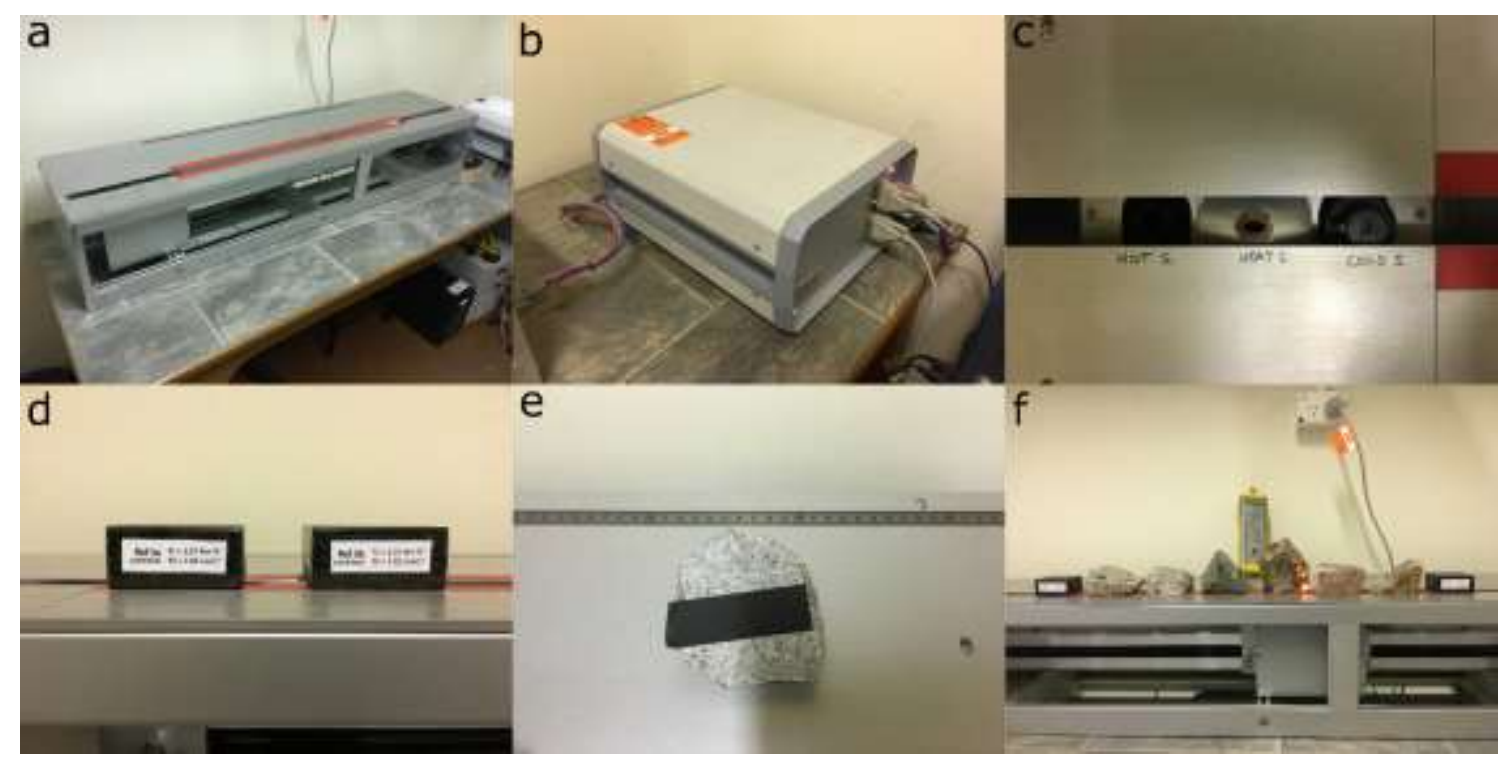

Figure 2 - Components of the thermal conductivity scanner (TCS). A - platform, B - stepper motor, C - optical head, D - reference standards, $\mathrm{E}$ - sample with black tape indicating scanning line, $\mathrm{F}$ - samples and standards aligned on platform

\section{SCANNING THE SAMPLES}

\section{Sample preparation}

Samples were generally selected based on their suitability for scanning so little preparation was needed in terms of cutting. The occasional sample needed to be re-cut or have the surface ground to ensure an appropriate measuring surface. Before scanning, the surface of each sample was wiped down with a damp cloth to remove any dust or foreign particles. After being allowed to dry, a strip of black tape was applied firmly to the surface of each sample ensuring no wrinkles or air pockets (Figure 2e). The tape was applied along the desired scanning line to ensure complete absorption of the infrared heat applied by the optical head.

The number of samples that can be measured at the same time is limited to how many fit together on the stage between the two appropriate reference standards supplied by the manufacturer (Figure 2f). The samples and standards must all be placed on the stage 
with the flat surface down and the tape aligned with the scanning line. The best quality measurements are produced when the standards used reflect the expected values of conductivity for the samples as close as possible. To ensure quality measurements over a wide range of conductivities, five separate standards of different conductivities are supplied with the TCS. The standards used for the bulk of this project were $3 \mathrm{a}$ and $3 \mathrm{~b}$ with known conductivity values of $2.37 \mathrm{~W} \mathrm{~m}^{-1} \mathrm{~K}^{-1}$ (Figure $2 \mathrm{~d}$ ). For samples with particularly high thermal conductivity (DB-002 and NN-NC4), standards 4a and 4b $\left(5.94 \mathrm{~W} \mathrm{~m}^{-1} \mathrm{~K}^{-1}\right)$ were used instead.

\section{Choosing a scanning line}

For smaller samples, the scan line was selected along the longest axis of the sample, preferably along the line of maximum thickness and at least 10mm (half the minimum width) from the sample edge. For samples of adequate size, the scanning line was selected along a representative portion of the sample.

Heat flow from the source is directed along the plane perpendicular to the scanning line. This means that empty cracks or fractures running parallel to the scan line would have the greatest influence on the measurements. If such cracks exist along the longest axis, the sample can still be measured provided the crack is treated as a de facto edge and the scanning line is an appropriate distance away. Cracks or fractures running perpendicular to the scanning line typically have a minimal effect on the measurement outcome but were either avoided or selected out of the results where possible. 


\section{Error minimization}

As with all data sets, errors are an inherent property and need to be minimized if and when possible. For the conductivity measurements obtained in this thesis, each individual sample had its own associated error. From the scanner output this error is conveyed as the inhomogeneity factor, $G$, and is related to the standard deviation, $\sigma$, and the sample mean, $k$, by

$$
\sigma=G k
$$

The standard deviation on the mean is reduced by performing multiple scans on the same sample. The amount that the error is reduced can be estimated using the equation for the propagation of error where $\sigma_{i}$ is the uncertainty on some function, $f\left(k_{i}\right)$.

$$
\sigma=\left(\sum_{i}\left(\frac{\partial f}{\partial k_{i}}\right)^{2} \sigma_{i}^{2}\right)^{1 / 2}
$$

In this case, $f$, is simply the arithmetic mean, allowing us to write estimated standard deviation as

$$
\bar{\sigma}=\frac{1}{n}\left(\sum_{i} \sigma_{i}^{2}\right)^{1 / 2}
$$

If all $\sigma_{i}$ 's are the same, this equation suggests the uncertainty in the mean is proportional to the square root of the number of samples, or in this case, the number of scans per sample. With this in mind, five scans were performed for each sample which in effect should reduce sample errors by approximately one half. 


\section{Mixing models and parameter estimation}

A number of mixing models have been proposed to describe thermal conductivity based on the geometric arrangement of the constituent elements (Beardsmore \& Cull, 2001; Clauser \& Huenges, 1995; Fuchs et al., 2013). I have chosen to focus on only four relatively common mixing models that can also be easily linearizes, which greatly simplifies the modelling. The arithmetic mean is already linear and therefore remains unchanged (Eq. (2)). This leaves the harmonic, geometric and square root means which now become

$$
\begin{gathered}
k_{\text {har }}^{-1}=\sum v_{i} k_{i}^{-1} \\
\log k_{g e o}=\sum v_{i} \log k_{i} \\
\sqrt{k_{S R M}}=\sum v_{i} \sqrt{k_{i}}
\end{gathered}
$$

where $v_{i}$ is the fraction of component $i$, normalized to 1 . From here the forward model is straight forward (Eq. (12) and can be obtained using the $m \times n$ operator matrix, $\boldsymbol{G}$, and known model vector, $\boldsymbol{m}$, with $n$ model parameters to produce an unknown data vector, $\boldsymbol{d}$, with $m$ values.

$$
\boldsymbol{G m}=\boldsymbol{d}
$$

In matrix form,

$$
\left[\begin{array}{ccc}
x_{1,1} & \ldots & x_{1, n} \\
\ldots & \ldots & \ldots \\
x_{m, 1} & \ldots & x_{m, n}
\end{array}\right]\left[\begin{array}{c}
m_{1} \\
\ldots \\
m_{n}
\end{array}\right]=\left[\begin{array}{c}
d_{1} \\
\ldots \\
d_{m}
\end{array}\right]
$$


$\mathbf{G}$ consists of the modal or normative mineral proportions, or oxide weight percent in the sample. Each row of $\mathbf{G}$ represents a sample and each column a mineral or oxide. In the situation where $\mathbf{d}$ consists of observed values and we wish to find the unknown model parameters $\mathbf{m}$, we need to use the inverse solution to Equation (12. For this, the most common approach is to minimise the sum of squares to obtain the least squares solution (Aster, Borchers, \& Thurber, 2013),

$$
\boldsymbol{m}_{L S}=\left(\boldsymbol{G}^{T} \boldsymbol{G}\right)^{-1} \boldsymbol{G}^{T} \boldsymbol{d}
$$

Provided that data errors are normally distributed, the least squares solution turns out to be statistically the most likely solution. When an estimate of the least squares model parameters has been obtained, the solution can then be placed back into the forward equation to compare the results with the observed data. In order to incorporate data error into the forward and inverse problems a weighting factor $\mathrm{W}$ may be applied to each sample. The weighting factor used in this thesis was the reciprocal of the sample variance

$$
W_{i}=\frac{1}{\sigma_{i}^{2}}
$$

With the weighting term added, the forward and inverse equations become

$$
\boldsymbol{G}_{w} \boldsymbol{m}=\boldsymbol{d}_{w}
$$

and 


$$
\boldsymbol{m}_{L S}=\left(\boldsymbol{G}_{w}^{T} \boldsymbol{G}_{w}\right)^{-1} \boldsymbol{G}_{w}^{T} \boldsymbol{d}_{w}
$$

respectively (Aster et al., 2013), where

$$
\boldsymbol{G}_{w}=\mathrm{WG}
$$

Model performance was determined by the root mean square misfit function

$$
R M S=\left(\frac{1}{n} \sum k_{o b s}-k_{m o d}\right)^{1 / 2}
$$

where $k_{o b s}$ are the observed thermal conductivity values and $k_{\text {mod }}$ are the modelled conductivity values.

\section{THE FORWARD MODEL}

An additional forward model was produced using modal estimates determined from the methods outlined previously. Laboratory derived conductivity values used in this model were compiled from a number of sources and averaged to provide a mean value for each mineral (Table 1). Mineral identification did not distinguish between solid solution endmembers for plagioclase or olivine. In both cases, an average conductivity was determined from the appropriate end-members and used as a representative thermal conductivity value for the mineral series. 
Table 1 - Laboratory derived mineral conductivities after 1 - Diment and Pratt (1988), 2 - Dreyer (1974), 3 - Horai (1971), and 4 - Cermak and Rybach (1982). Mean values are derived by taking the average of reported values for each mineral. In the case where a minimum and maximum value are reported in one paper, the geometric mean of both is taken before taking the average of this mean for all reported values. Minimum and maximum values in this table are absolute values across all four references. *Perthite determined as the average of orthoclase and plagioclase. **Olivine determined as the average of fayalite and forsterite values from each paper.

\begin{tabular}{lcccl}
\multicolumn{5}{c}{ Thermal Conductivity $\left[\mathrm{W} \mathrm{m}^{-1} \mathrm{~K}^{-1}\right]$} \\
Mineral & Mean & Min & Max & Reference \\
\hline Quartz & 7.97 & 6.15 & 11.30 & $1,2,3,4$ \\
Orthoclase & 2.37 & 2.31 & 2.68 & $1,3,4$ \\
Plagioclase & 2.20 & 2.00 & 2.72 & $1,2,3,4$ \\
Perthite* & 2.29 & 2.20 & 2.37 & - \\
Biotite & 1.49 & 0.52 & 3.14 & $1,3,4$ \\
Clinopyroxene & 4.45 & 4.23 & 4.66 & 1,3 \\
Hornblende & 2.88 & 2.81 & 2.91 & $1,2,3$ \\
Olivine** & 4.08 & 3.16 & 5.06 & $1,3,4$ \\
Spinel & 11.23 & 9.48 & 12.14 & $1,2,3,4$
\end{tabular}




\section{OBSERVATIONS AND RESULTS}

\section{Sample compositions and classification}

To apply the results to a broad a range of igneous rock types, it was important that the sample set be representative of both the compositional and mineralogical variations found in nature. Compositionally the samples range from 33.4 to $99.7 \% \mathrm{SiO}_{2}$ and encapsulate a distribution similar to that of Hasterok and Webb (2017) who compiled data on over 108 thousand chemical analyses of igneous rock compositions (Figure 3a). Samples from this paper appear to conform well to areas of high data-density (seen as darker colours in Figure 3a) suggesting good representation of global compositional trends. Each sample was classified according to composition (Middlemost, 1994) and basic statistics were recorded for each rock type including observed and estimated thermal conductivity as well as estimated P-wave velocity and density after Behn and Kelemen (2003) (Table 2).

Normative mineralogy produces a reasonable distribution among rock types although plagioclase is favoured strongly over the alkali feldspars (Figure $3 b$ ). From high to low quartz content, a distinct decreasing trend is evident in thermal conductivity values, expectedly due to the high thermal conductivity of quartz $\left(7.97 \mathrm{~W} \mathrm{~m}^{-1} \mathrm{~K}^{-1}\right)$ compared to the feldspars $\left(\sim 2.3 \mathrm{~W} \mathrm{~m}^{-1} \mathrm{~K}^{-1}\right)$. Estimated mineralogy show a less defined trend but still appears to decrease in a similar fashion (Figure 3c). For the purpose of plotting estimated mineralogy, modal values of perthite (typically an intergrowth of k-feldspar and albite) were assigned equally to both plagioclase and alkali feldspar. 

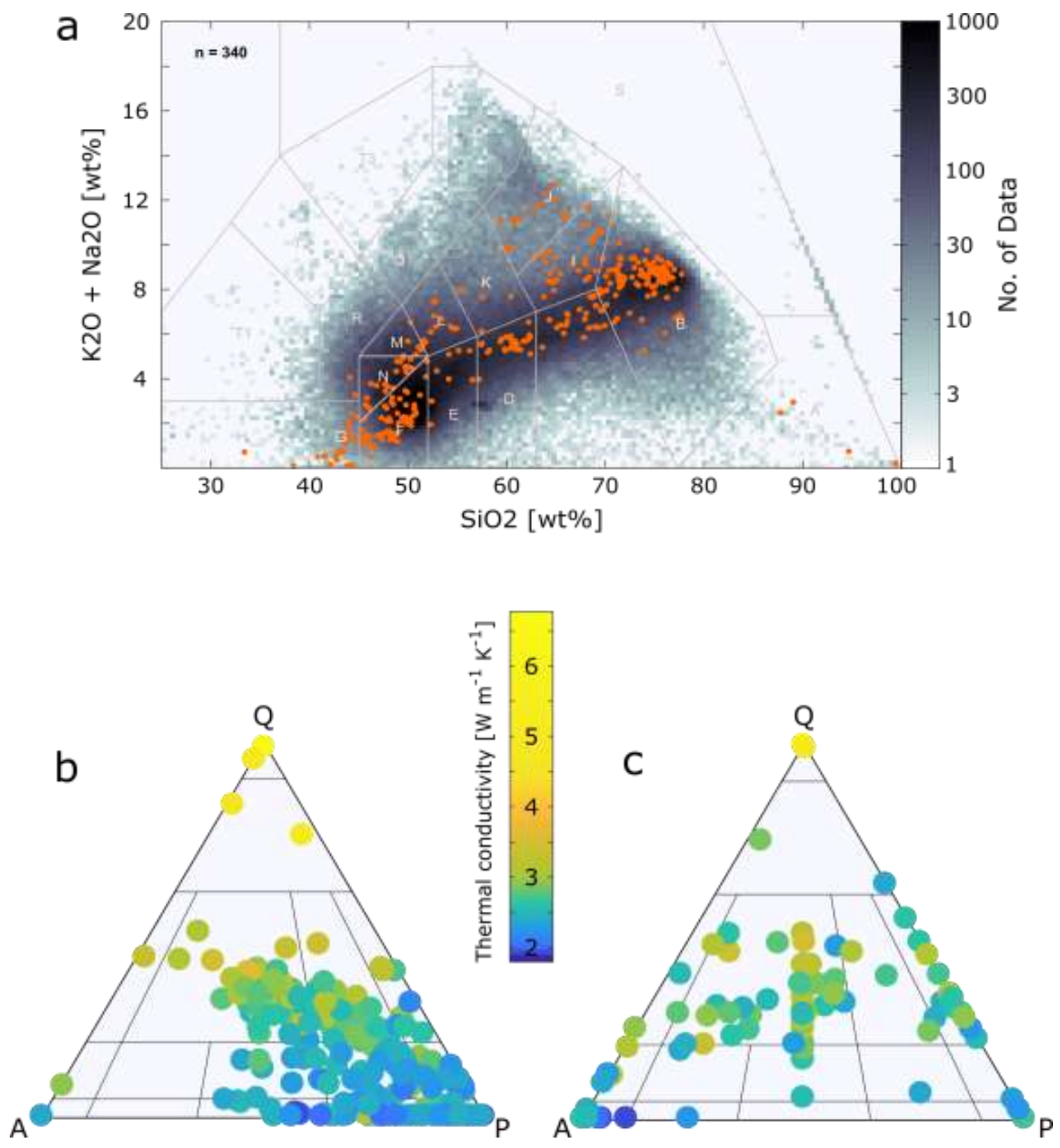

Figure 3 - Sample classification. a) Total alkali silica (TAS) classification scheme after Middlemost (1994), greyscale points represent a $2 d$ histogram of compositional data from $108+$ thousand igneous rock samples (Hasterok \& Webb, 2017), orange points represent data from this thesis. See Table 2 for TAS names B) Quartz-Alkali Feldspar-Pagioclase (QAP) classification after Streckeisen (1974) for CIPW normative mineralogy. Colours represent observed thermal conductivity values, c) QAP classification for estimated mineral modes. Colours represent observed thermal conductivity values. 
Table 2 - Observed and estimated physical properties. Preferred thermal conductivity model is the major oxide calibrated using a geometric mixing model.

\begin{tabular}{|c|c|c|c|c|c|c|c|c|c|c|c|c|c|c|c|c|c|c|}
\hline \multirow[t]{2}{*}{$\begin{array}{l}\text { TAS } \\
\text { Field }\end{array}$} & \multirow[t]{2}{*}{ Rock Type } & \multirow[t]{2}{*}{$\mathrm{N}$} & \multicolumn{4}{|c|}{$\begin{array}{c}\text { Observed } \\
\text { Thermal Conductivity } \\
{\left[\mathrm{W} \mathrm{m}^{-1} \mathrm{~K}^{-1}\right]}\end{array}$} & \multicolumn{4}{|c|}{$\begin{array}{c}\text { Preferred Model } \\
\text { Thermal Conductivity } \\
{\left[\mathrm{W} \mathrm{m}^{-1} \mathrm{~K}^{-1}\right]}\end{array}$} & \multicolumn{4}{|c|}{$\begin{array}{c}\text { Estimated } \\
\text { P-wave velocity } \\
{\left[\mathrm{km} \mathrm{s}^{-1}\right]} \\
\end{array}$} & \multicolumn{4}{|c|}{$\begin{array}{l}\text { Estimated density } \\
{\left[\mathrm{kg} \mathrm{m}^{-3}\right]}\end{array}$} \\
\hline & & & $k$ & $\sigma$ & Min & Max & $k_{e f f}$ & $\sigma$ & Min & Max & $V p$ & $\sigma$ & Min & Max & $\rho$ & $\sigma$ & Min & Max \\
\hline \multicolumn{19}{|c|}{ Subalkaline } \\
\hline A & Quartzite & 4 & 5.47 & 0.89 & 4.76 & 6.77 & 4.67 & 0.60 & 4.03 & 5.33 & 6.10 & 0.32 & 5.81 & 6.46 & 2679 & 45 & 2624 & 2734 \\
\hline B & Granite & 106 & 2.94 & 0.29 & 2.16 & 3.69 & 2.86 & 0.14 & 2.57 & 3.26 & 6.13 & 0.06 & 6.04 & 6.38 & 2632 & 72 & 2543 & 3189 \\
\hline B & Rhyolite & 4 & 2.83 & 0.43 & 2.53 & 3.47 & 2.72 & 0.19 & 2.60 & 3.01 & 6.16 & 0.05 & 6.08 & 6.19 & 2602 & 22 & 2588 & 2634 \\
\hline C & Granodiorite & 22 & 2.80 & 0.33 & 2.31 & 3.34 & 2.65 & 0.10 & 2.52 & 2.91 & 6.39 & 0.18 & 6.25 & 7.12 & 2721 & 104 & 2570 & 3007 \\
\hline C & Dacite & 1 & 2.59 & - & - & - & 2.59 & - & - & - & 6.30 & - & - & - & 2616 & - & - & - \\
\hline D & Diorite & 29 & 2.47 & 0.19 & 2.14 & 2.91 & 2.43 & 0.05 & 2.35 & 2.56 & 6.60 & 0.05 & 6.54 & 6.74 & 2757 & 46 & 2628 & 2845 \\
\hline D & Andesite & 1 & 2.90 & - & - & - & 2.42 & - & - & - & 6.46 & - & - & - & 2719 & - & - & - \\
\hline$E$ & Gabbroic diorite & 8 & 2.52 & 0.39 & 1.94 & 3.23 & 2.44 & 0.12 & 2.31 & 2.71 & 6.93 & 0.20 & 6.72 & 7.25 & 2938 & 234 & 2630 & 3320 \\
\hline $\mathrm{F}$ & Subalkalic gabbro & 60 & 2.34 & 0.29 & 1.84 & 3.08 & 2.33 & 0.13 & 2.03 & 2.73 & 7.32 & 0.21 & 6.79 & 7.82 & 2969 & 128 & 2621 & 3492 \\
\hline G & Peridotgabbro & 17 & 2.66 & 0.31 & 2.05 & 3.14 & 2.51 & 0.30 & 2.05 & 3.04 & 7.60 & 0.48 & 5.94 & 8.07 & 3061 & 122 & 2922 & 3394 \\
\hline $\mathrm{H}$ & Cumulate peridotite & 1 & 1.84 & - & - & - & 2.65 & - & - & - & 8.02 & - & - & - & 3067 & - & - & - \\
\hline $\mathrm{H}$ & Mantle peridotite & 2 & 2.42 & 0.08 & 2.37 & 2.48 & 2.73 & 0.02 & 2.71 & 2.74 & 7.90 & 0.01 & 7.90 & 7.91 & 2690 & 140 & 2591 & 2788 \\
\hline \multicolumn{19}{|c|}{ Alkaline } \\
\hline । & Quartz monzonite & 25 & 2.40 & 0.18 & 2.05 & 2.83 & 2.40 & 0.12 & 2.10 & 2.69 & 6.32 & 0.14 & 6.14 & 6.89 & 2639 & 84 & 2560 & 2927 \\
\hline । & Trachydacite & 1 & 2.88 & - & - & - & 2.46 & - & - & - & 6.26 & - & - & - & 2635 & - & - & - \\
\hline J & Syenite & 15 & 2.13 & 0.27 & 1.80 & 2.65 & 2.17 & 0.09 & 2.09 & 2.36 & 6.32 & 0.11 & 6.13 & 6.50 & 2611 & 35 & 2557 & 2660 \\
\hline K & Monzonite & 4 & 2.21 & 0.24 & 2.03 & 2.55 & 2.17 & 0.16 & 1.96 & 2.32 & 6.65 & 0.14 & 6.50 & 6.84 & 2763 & 117 & 2610 & 2891 \\
\hline $\mathrm{L}$ & Monzodiorite & 10 & 2.42 & 0.20 & 2.13 & 2.76 & 2.33 & 0.18 & 2.04 & 2.63 & 6.76 & 0.25 & 6.29 & 7.22 & 2848 & 100 & 2665 & 2985 \\
\hline L & Basaltic trachyandesite & 2 & 2.58 & 0.14 & 2.48 & 2.67 & 2.17 & 0.00 & 2.17 & 2.18 & 6.73 & 0.03 & 6.71 & 6.75 & 2800 & 13 & 2791 & 2810 \\
\hline M & Monzogabbro & 6 & 2.32 & 0.15 & 2.09 & 2.48 & 2.30 & 0.05 & 2.21 & 2.36 & 6.74 & 0.25 & 6.33 & 7.10 & 2878 & 29 & 2833 & 2916 \\
\hline$N$ & Alkalic gabbro & 20 & 2.45 & 0.21 & 2.09 & 2.86 & 2.30 & 0.16 & 2.00 & 2.53 & 6.99 & 0.30 & 5.94 & 7.38 & 2907 & 102 & 2657 & 3084 \\
\hline \multicolumn{19}{|c|}{ Foid Bearing } \\
\hline $\mathrm{R}$ & Foid gabbro & 2 & 2.21 & 0.11 & 2.13 & 2.29 & 2.26 & 0.03 & 2.24 & 2.29 & 7.05 & 0.02 & 7.03 & 7.07 & 2806 & 128 & 2716 & 2897 \\
\hline All Ro & ck Types & 340 & 2.64 & 0.50 & 1.80 & 6.77 & 2.55 & 0.12 & 1.96 & 5.33 & 6.75 & 0.13 & 5.81 & 8.07 & 2778 & 72.4 & 2543 & 3492 \\
\hline
\end{tabular}




\section{Thermal conductivity vs model parameters}

Variations in thermal conductivity between rock types clearly indicate a general compositional effect with $\mathrm{SiO}_{2}$-rich rocks having higher conductivity than low-SiO rock types (Table 2). However, this relationship is far more complex than a single compositional variable. Figure 4, Figure 6 and Figure 5 show how thermal conductivity varies as a function of major oxides, normative mineralogy and modal proportions respectively.

From the major oxides (Figure 4), it can be seen that $\mathrm{SiO}_{2}$ shows a non-linear positive trend where conductivity increases significantly with values greater than $\sim 60 \% . \mathrm{K}_{2} \mathrm{O}$ displays a positive linear relationship with conductivity albeit to a lesser degree than $\mathrm{SiO}_{2} . \mathrm{Al}_{2} \mathrm{O}_{3}$ has a strong negative relationship with conductivity, particularly between 10 to $20 \%$, while $\mathrm{TiO}_{2}, \mathrm{FeO}, \mathrm{MgO}, \mathrm{CaO}$ and $\mathrm{LOI}$ all display weak negative trends. The relationship between $\mathrm{Na}_{2} \mathrm{O}$ and conductivity is open to interpretation but may show a slight hump around $4 \%$ before decreasing.

Despite a significantly smaller samples size, trends are also apparent in the estimated mineralogy (Figure 5). Quartz shows a positive relationship with conductivity similar to that of the higher $(>60 \%) \mathrm{SiO}_{2}$ values while orthoclase and perthite both display decreasing trends above values of $\sim 50 \%$ but remain seemingly constant at lesser values. Of the rest, hornblende shows a slight negative correlation while plagioclase, biotite and clinopyroxene show no definitive trend either way. Trends may be present in olivine and spinel but the small sample size of each $(n=11)$ leaves a lot to interpretation. 

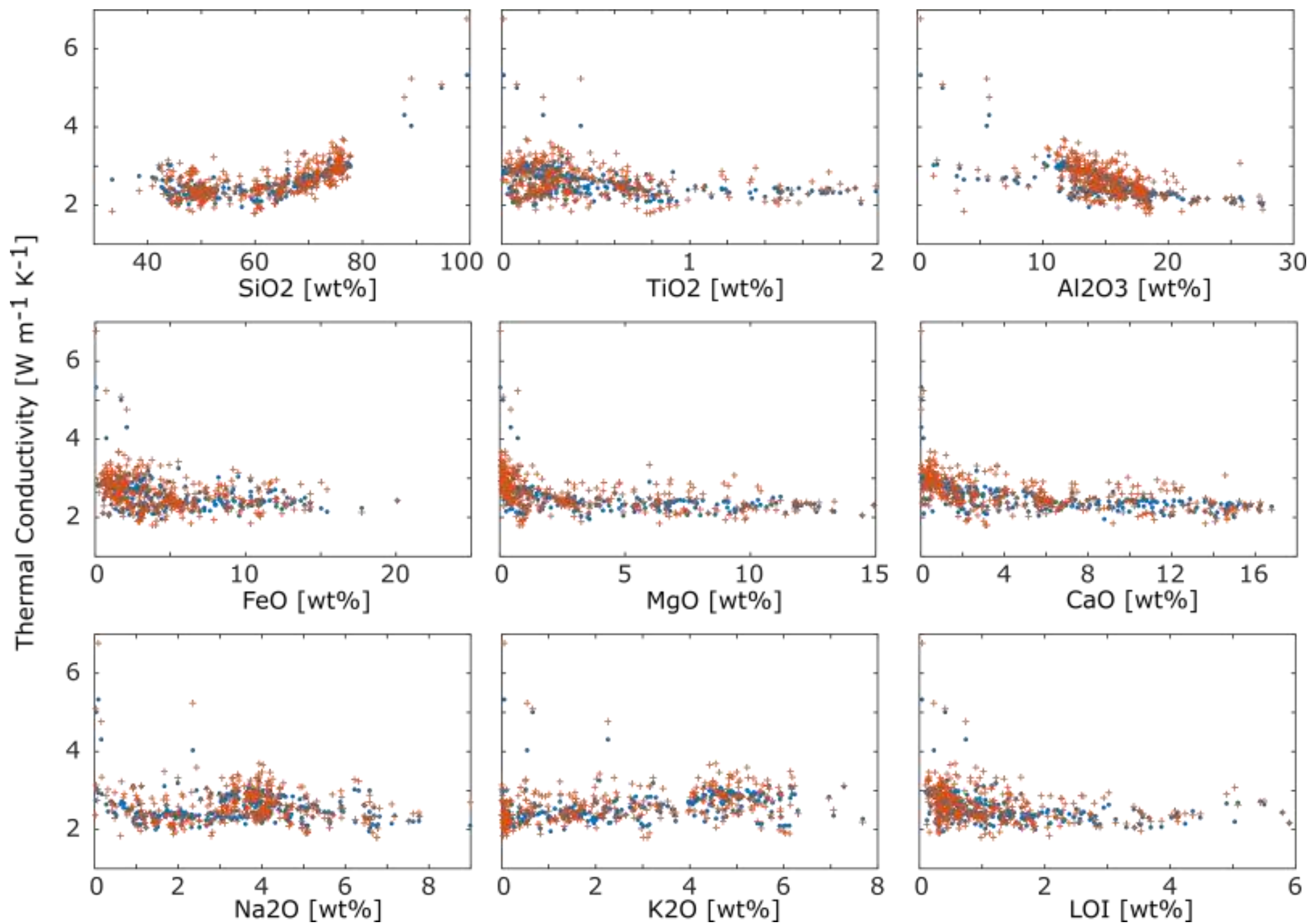

Figure 4 - Relationship between thermal conductivity and the major oxides. Red crosses represent the observed conductivity values for each sample. Blue dots represent the estimated conductivity values using a weighted geometric mixing model. 

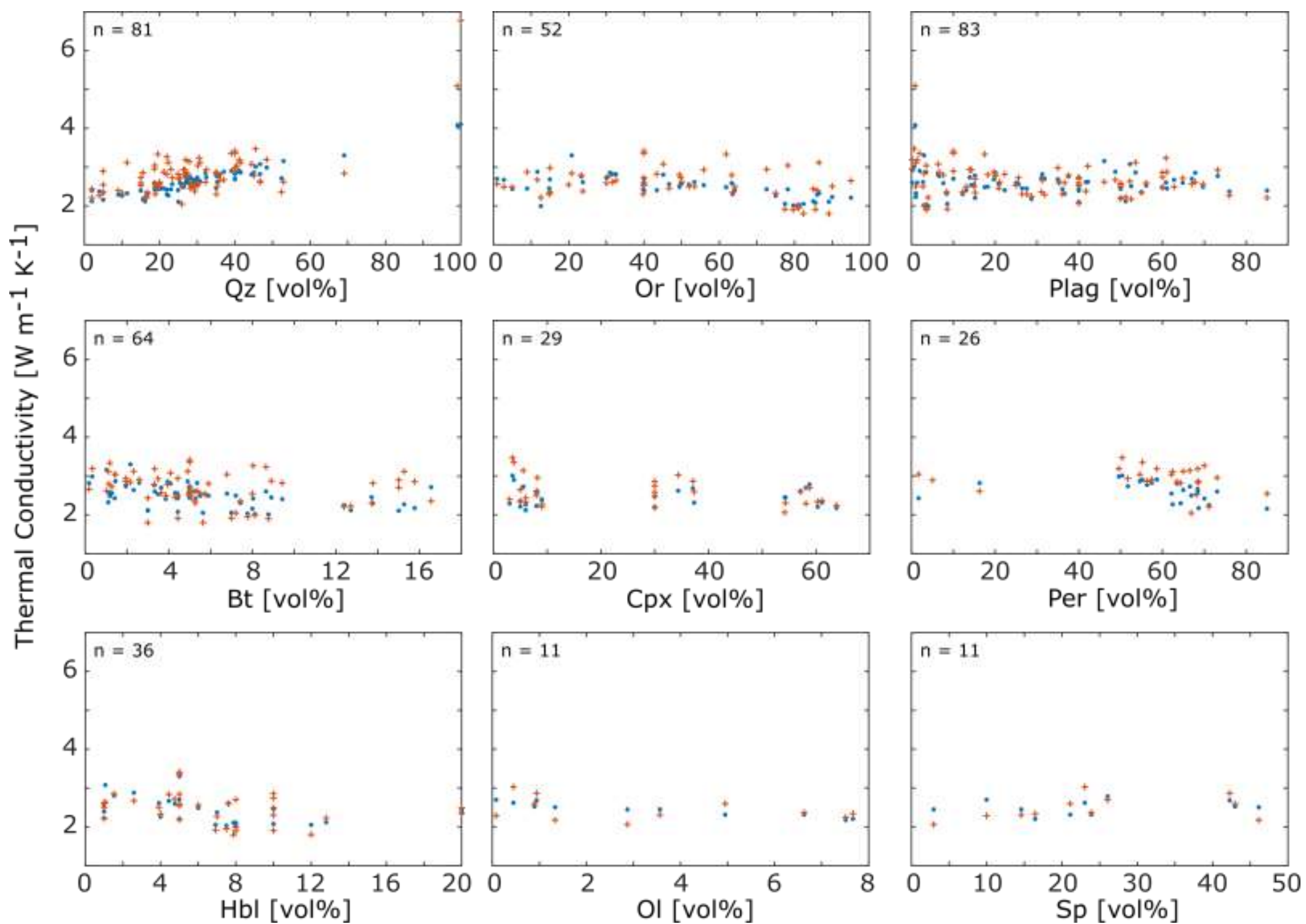

Figure 5 - Relationship between thermal conductivity and estimated modal mineralogy. Red crosses represent the observed conductivity values for each sample. Blue dots represent the estimated conductivity values using a weighted geometric mixing model. $\mathrm{Qz}-$ quartz; Or orthoclase; Plag - plagioclase; Per - perthite; Bt - biotite; Hbl - horblende; Cpx - clinopyroxene; Ol - olivine; Sp - spinel. 

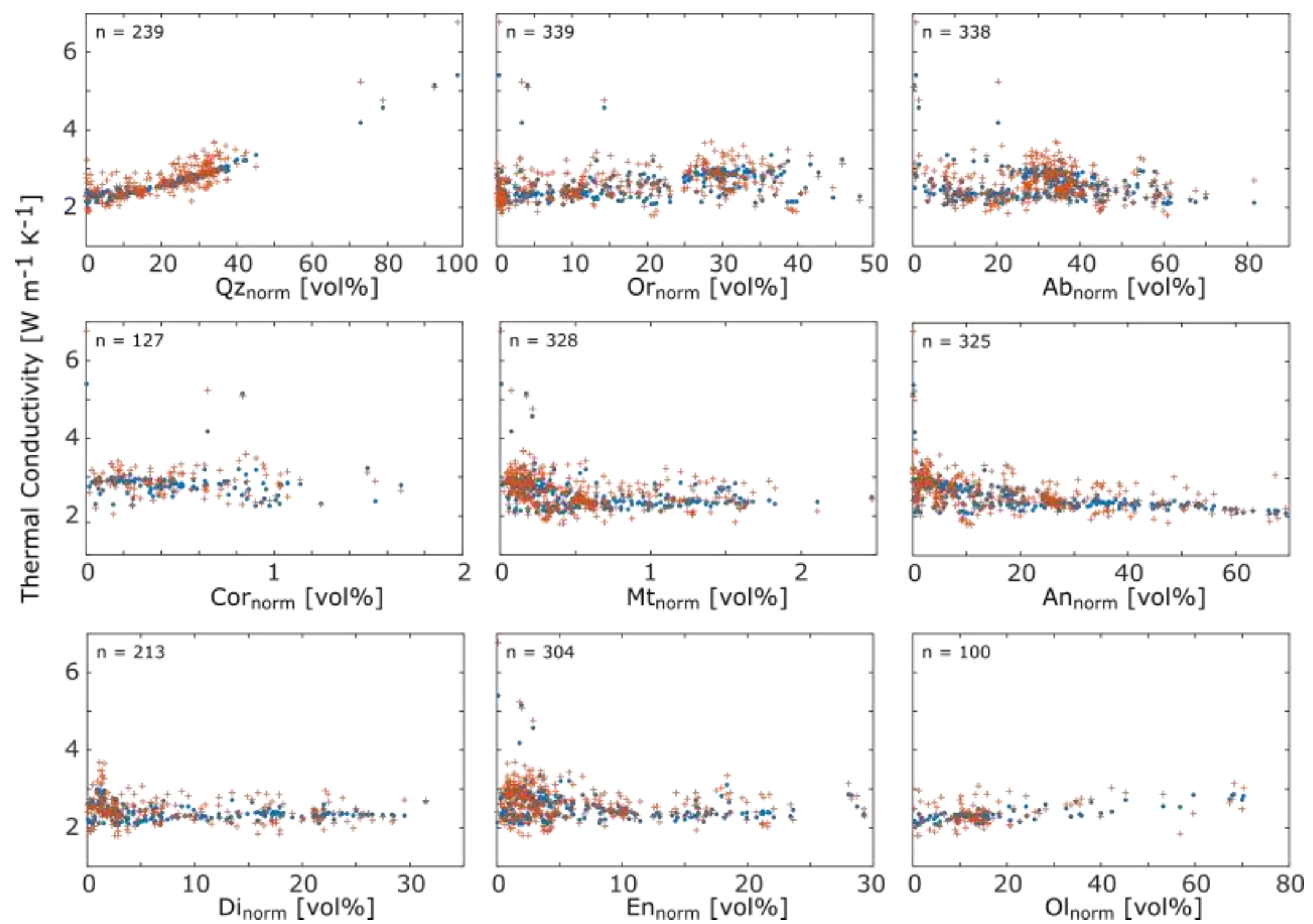

Figure 6 - Relationship between thermal conductivity and the calculated CIPW mineralogy. Red crosses represent the observed conductivity values for each sample. Blue dots represent the estimated conductivity values using a weighted geometric mixing model. Qz quartz; Or - orthoclase; Ab - albite; Cor - corundum; Mt - magnetite; An - anorthite; Di - diopside; En - enstatite; Ol - olivine. 
Similar trends are again seen when the normative minerals are plotted against thermal conductivity (Figure 6). Quartz shows a strong positive trend throughout the entire range, increasing steadily from 0 through to $\sim 100 \%$. Orthoclase also displays a positive relationship, however it appears to plateau after $\sim 30 \%$ rather than continue in the same manner that quartz does. Olivine shows a slight positive trend although the data become messy at higher values. Plagioclase appears to show the only reasonably negative trend while the remaining normative minerals show no strong relationship either way.

\section{Modelling}

Weighted and unweighted linear-least squares regression analysis was used to model the effect of major oxide composition, CIPW normative mineralogy, and estimated modal mineralogy on thermal conductivity values. The major oxide regression was performed using eight of the most commonly reported oxides plus loss on ignition. For the CIPW model, the nine most frequently occurring minerals were used with the caveat that mutually exclusive pairs such as quartz and olivine as well as corundum and diopside be included regardless. Regression for the estimated mineral modes was performed using the nine most frequently occurring minerals. The performance of each regression was determined based on the RMS values of each mixing model and was compared to the results of the forward mineralogy model (Table 3).

Table 3 - Comparison of RMS values for each mixing model. $\mathrm{UW}=$ unweighted, $\mathrm{W}=$ weighted, $\mathrm{F}=$ forward. Models are weighted by the inverse of the sample variance (15).

\begin{tabular}{lccccccc} 
& \multicolumn{2}{c}{ Oxides } & \multicolumn{2}{c}{ CIPW } & \multicolumn{3}{c}{ Modal Mineralogy } \\
& UW & W & UW & W & UW & W & F \\
\hline Arithmetic & 0.263 & 0.289 & 0.266 & 0.290 & 0.389 & 0.456 & 1.503 \\
Geometric & 0.246 & 0.270 & 0.250 & 0.271 & 0.370 & 0.435 & 0.969 \\
Square Root Mean & 0.254 & 0.282 & 0.259 & 0.284 & 0.397 & 0.464 & 1.213 \\
Harmonic & 0.314 & 0.331 & 0.325 & 0.396 & 0.348 & 0.388 & 0.667
\end{tabular}


For each model produced, the unweighted version performed slightly better than the weighted version by $\sim 0.02 \mathrm{~W} \mathrm{~m}^{-1} \mathrm{~K}^{-1}$. In both cases the major oxide model produced a slightly better fit than the CIPW model and significantly better than the estimated modal mineralogy. For both the oxide and CIPW models, the geometric mean produced the best results while the harmonic mean produced the best for the modal mineralogy model. The performance of all three models produced using estimated modal mineralogy was significantly worse than those using oxide composition and CIPW mineralogy. Using estimated mineral modes and mineral conductivity values from Table 1, the forward model produced an extremely poor fit to observed data regardless of the mixing model being used. 


\section{DISCUSSION}

\section{Model performance}

Of the three regression models, the best results overall came from the model derived from major oxide composition (Table 3). The unweighted regression had better results than the weighted; however, the weighted model takes into account data uncertainty and should be considered a truer representation of the data quality. For this reason I will focus this discussion on the weighted models only.

For the bulk of the data, visual analysis of the residuals does not indicate any significant difference between the mixing models (Figure 7). Between $40-50 \% \mathrm{SiO}_{2}$ the harmonic mean (Figure 7d) appears to slightly overestimate conductivity and this misfit becomes apparent when comparing RMS values between the models (Table 3). Any remaining variation in RMS values between the models appears to come from both the high (>80\%) and low (>40\%) $\mathrm{SiO}_{2}$ data. In these regions, the geometric model (Figure $7 \mathrm{~b}$ ) appears to have a slightly better fit than both the arithmetic (Figure 7a) and square root mean (Figure 7c). The difference in RMS values between these three mixing models is only $0.02 \mathrm{~W} \mathrm{~m}^{-1} \mathrm{~K}^{-1}$, suggesting any could be used to a similar degree of accuracy, however, general consensus from the literature (Clauser, 2011; Fuchs et al., 2013) would give preference towards the geometric model in this circumstance. 
Sam Jennings

A new thermal conductivity model

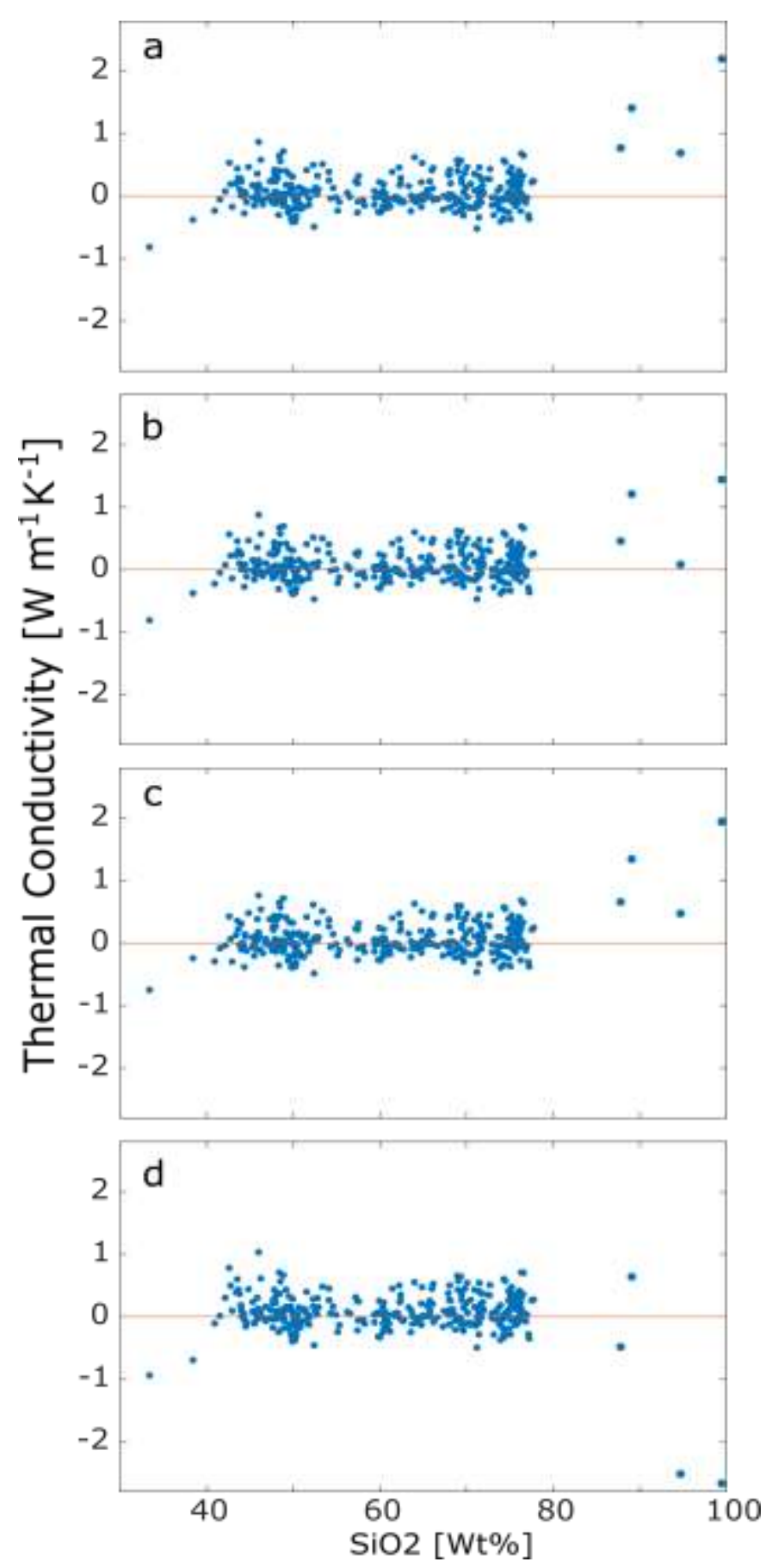

Figure 7 - Model residuals from the major oxide model using different mixing models. a) arithmetic, b) geometric, c) square root mean, d) harmonic 
Coefficients for each mixing model are presented in linear space in Figure 8 along with the estimated standard error. These are determined from the regression and used in the forward model to estimate the conductivity of each sample. In theory, these coefficients represent the thermal conductivity of each model parameter and have units of $\mathrm{W} \mathrm{m}^{-1} \mathrm{~K}^{-1}$. Despite being purely theoretical, the coefficients can be compared to actual thermal conductivity values to gain insight into the performance and reliability of the model.

The most notable aspect in examining the model coefficients is that the estimated standard error for each parameter, while using the harmonic mean, is so large that in most cases it extends past the y-axis limits (Figure 8). This would suggest that the error in estimating conductivity using the harmonic mean, while reasonably similar in terms of RMS value, has a much larger degree of error than using the other mixing models. The coefficients of the arithmetic mean, when compared to the geometric and square root, appear to be quite reasonable for the CIPW model (Figure 8b) and to some extent the modal mineralogy model (Figure 8c). The presence of negative values, particularly within the major oxide model, suggests a significant deviation from reality in order for the arithmetic model work. The coefficients of the geometric and square root are similar and show only slight variations from each other across the three models. A major difference between the two is the value of $\mathrm{TiO}_{2}$ (Figure 8a), which has a limited effect (low sensitivity) on model performance. 


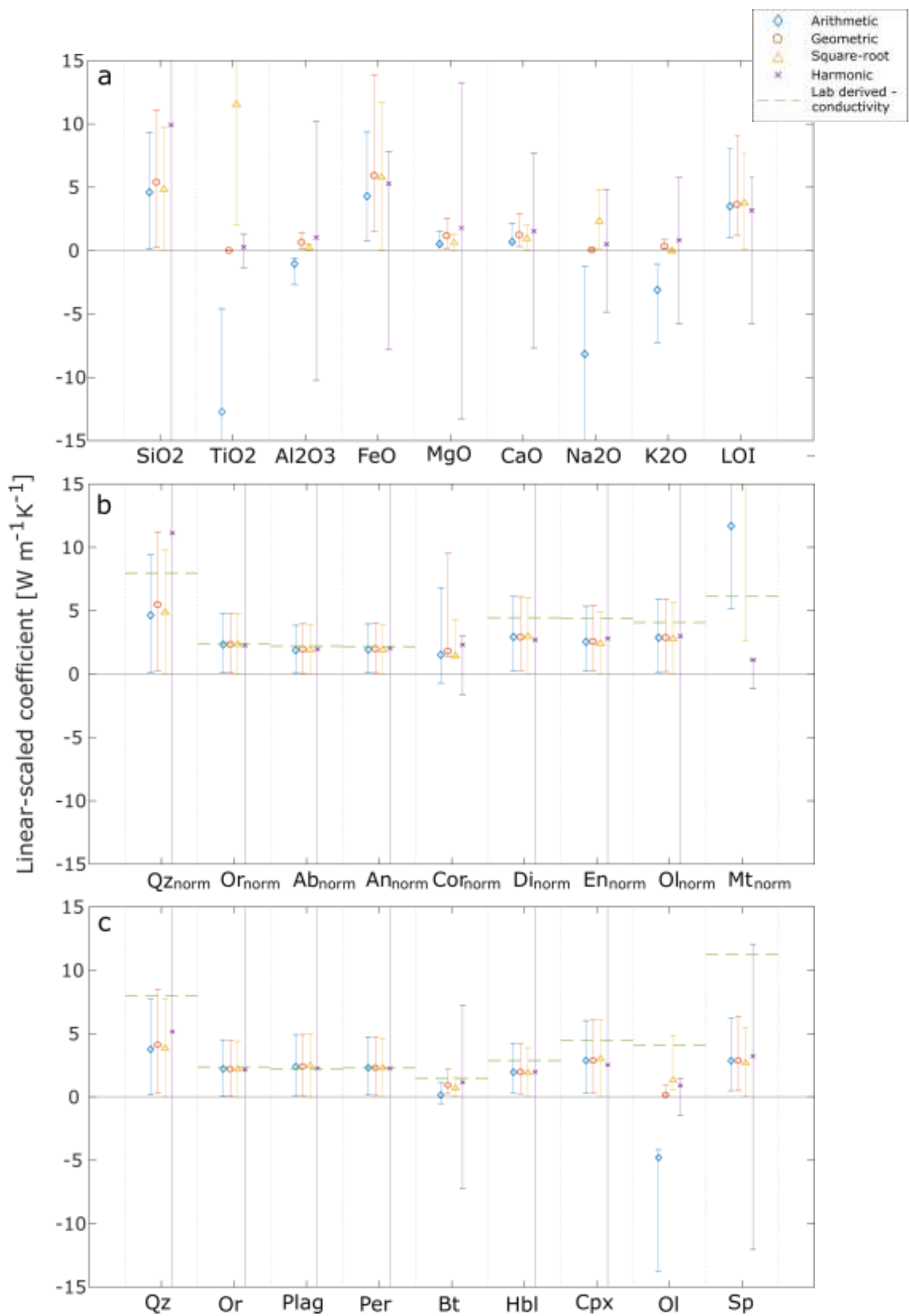

Figure 8 - Model coefficients and standard errors in linear space for a) the major oxide model, b) the CIPW model and c) the modal mineralogy model. Note: the geometric coefficient for magnetite in the CIPW model has a value of $\sim 83 \mathrm{~W} \mathrm{~m} \mathrm{~m}^{-1} \mathrm{~K}^{-1}$ and is not displayed on the figure. Similarly, the laboratory value for corundum is $26.44 \mathrm{~W} \mathrm{~m} \mathrm{~m}^{-1} \mathrm{~K}^{-1}$ and is also not shown on the figure. Qz - quartz; Or - orthoclase; Ab - albite; Cor - corundum; Mt - magnetite; An anorthite; Di - diopside; En - enstatite; Ol - olivine; Plag - plagioclase; Per - perthite; Bt biotite; Hbl - hornblende; Cpx - clinopyroxene; $\mathrm{Sp}$ - spinel. 
For plutonic rock types, $\mathrm{SiO}_{2}$ content is the most important control on thermal conductivity. This is evidenced by the relatively large coefficient of $\mathrm{SiO}_{2}\left(\sim 5.5 \mathrm{~W} \mathrm{~m}^{-1}\right.$ $\mathrm{K}^{-1}$ ) in comparison to the other oxides. While $\mathrm{FeO}$ shows a similar value, the comparatively high abundance of $\mathrm{SiO}_{2}$ in each sample means the latter has the greater influence on conductivity. Due its high abundance, it is likely that the conductivity of any sample is controlled primarily by $\mathrm{SiO}_{2}$ content while a combination of the remaining oxides work to constrain the final magnitude. The estimated conductivity of a sample with very high $\mathrm{SiO}_{2}$ will likely approach the value of the $\mathrm{SiO}_{2}$ coefficient while a sample with low $\mathrm{SiO}_{2}$ will have a value reflecting a combination of the remaining oxides proportional to their abundance. In saying this, it might be expected that a sample composed of $100 \% \mathrm{SiO}_{2}$ should have the same conductivity value as that of quartz $\left(7.97 \mathrm{~W} \mathrm{~m}^{-1} \mathrm{~K}^{-1}\right)$. This will not be the case due to the presence of $\mathrm{SiO}_{2}$ in a wide range of rock compositions including those devoid of quartz.

On the other hand, both modal and mineralogy based models show far less variability in their coefficients values. With the exception of quartz and magnetite, the difference between the highest and lowest CIPW model coefficients is only $\sim 1 \mathrm{~W} \mathrm{~m}^{-1} \mathrm{~K}^{-1}$ (Figure 8b). A similar trend can be seen in the estimated mineralogy model where, with the exception of quartz, olivine and biotite, the minerals vary by only $0.9 \mathrm{~W} \mathrm{~m}^{-1} \mathrm{~K}^{-1}$. This is of course at odds with the natural variation in conductivities between these minerals and it can be seen that the model coefficients in most cases appear to underestimate compared to the laboratory derived conductivities. In particular, the coefficient of quartz in both the CIPW and estimated mineralogy models is less than the laboratory value of quartz by 3 to $4 \mathrm{~W} \mathrm{~m}^{-1} \mathrm{~K}^{-1}$. The exception to these mismatched estimates are the 
feldspar coefficients which in both models appear to closely resemble their laboratory values. This may mean that the feldspars are indeed the most important factor in determining thermal conductivity for plutonic rocks as suggested by Clauser (2011).

A couple of reasons exist that may explain why the mineral coefficients do not more closely resemble their laboratory counterparts. Despite due care being taken in the process, the estimated mineral modes may not be representative of the true composition. This may be a result of inaccuracy in the methods or possibly due to the presence of accessory minerals that were not accounted for. Assuming that modal estimations were in fact correct, another reason exists that may account for dissimilar coefficients and laboratory conductivity values. The reported minerals do not take into account that both plagioclase and olivine are in fact solid solution series, the end-members of which have differing values of thermal conductivity. For olivine, the Fe-rich end-member fayalite has conductivity value of $3.16 \mathrm{~W} \mathrm{~m}^{-1} \mathrm{~K}^{-1}$ while the $\mathrm{Mg}$-rich end-member forsterite has a conductivity value of $5.03 \mathrm{~W} \mathrm{~m}^{-1} \mathrm{~K}^{-1}$ (Horai, 1971). It is easy to see how such a difference in values could affect the model results when the presence of mineral solid solutions such as olivine and, to a lesser extent, plagioclase are not accounted for.

\section{Model sensitivities}

With the geometric mean established as the preferred mixing model, it is now possible to investigate the sensitivities of the inverse model. The effect of each model parameter can be determined by looking at the model coefficients produced during the regression. To explore the sensitivities we can examine the effect on the coefficients and RMS values as one or more parameters are removed from the regression (Table 4). 
Table 4 - Sensitivities of the model coefficients to major oxides. Each column represents the coefficient for a particular model parameter with each row representing a unique regression analysis with one (top half) or more (bottom half) parameters removed. For the top half of the table, the left hand column indicates which individual parameter was left out of the analysis. The bottom half of the table displays results from the cumulative removal of the least sensitive parameter after each step. The parameter indicated in the left hand column is not included in the regression analysis for that row. $\triangle R M S$ is calculated as the new RMS - RMS (all).

\begin{tabular}{|c|c|c|c|c|c|c|c|c|c|c|c|}
\hline & $\mathrm{SiO} 2$ & $\mathrm{TiO} 2$ & Al2O3 & $\mathrm{FeO}$ & $\mathrm{MgO}$ & $\mathrm{CaO}$ & $\mathrm{Na} 2 \mathrm{O}$ & $\mathrm{K} 2 \mathrm{O}$ & LOI & RMS & $\Delta$ RMS \\
\hline All & 1.686 & -5.855 & -0.448 & 1.777 & 0.153 & 0.216 & -2.986 & -1.064 & 1.291 & 0.270 & \\
\hline \multicolumn{12}{|c|}{ Sensitivity to exclusion of individual oxides } \\
\hline $\mathrm{SiO} 2$ & - & -10.095 & 2.637 & 3.475 & 1.259 & -0.654 & 4.261 & 5.766 & 0.907 & 0.717 & 0.447 \\
\hline $\mathrm{TiO} 2$ & 1.697 & - & -0.288 & 0.960 & 0.438 & 0.003 & -3.481 & -1.287 & 1.041 & 0.269 & -0.001 \\
\hline $\mathrm{Al} 2 \mathrm{O} 3$ & 1.649 & -5.129 & - & 1.797 & 0.207 & -0.281 & -3.498 & -1.369 & 1.167 & 0.274 & 0.004 \\
\hline $\mathrm{FeO}$ & 1.732 & 2.757 & -0.493 & - & 0.634 & 0.430 & -3.283 & -1.231 & 1.197 & 0.273 & 0.003 \\
\hline MgO & 1.693 & -6.600 & -0.479 & 1.896 & - & 0.274 & -2.989 & -1.100 & 1.510 & 0.269 & -0.001 \\
\hline $\mathrm{CaO}$ & 1.683 & -5.590 & -0.311 & 1.802 & 0.181 & - & -3.182 & -1.223 & 1.246 & 0.269 & -0.001 \\
\hline $\mathrm{Na} 2 \mathrm{O}$ & 1.559 & -9.208 & -1.211 & 1.968 & 0.159 & 1.281 & - & 0.104 & 1.683 & 0.314 & 0.044 \\
\hline K2O & 1.625 & -6.620 & -0.678 & 1.831 & 0.201 & 0.653 & -2.397 & - & 1.242 & 0.283 & 0.013 \\
\hline LOI & 1.678 & -4.814 & -0.335 & 1.744 & 0.506 & 0.072 & -3.196 & -0.998 & - & 0.272 & 0.002 \\
\hline \multicolumn{12}{|c|}{ Cumulative sensitivity to oxide exclusion } \\
\hline$-\mathrm{MgO}$ & 1.693 & -6.600 & -0.479 & 1.896 & - & 0.274 & -2.989 & -1.100 & 1.510 & 0.269 & -0.001 \\
\hline$-\mathrm{CaO}$ & 1.691 & -6.426 & -0.305 & 1.958 & - & - & -3.250 & -1.321 & 1.503 & 0.268 & -0.002 \\
\hline$-\mathrm{TiO} 2$ & 1.729 & - & -0.253 & 1.054 & - & - & -3.831 & -1.622 & 1.737 & 0.268 & -0.002 \\
\hline$-\mathrm{FeO}$ & 1.806 & - & -0.104 & - & - & - & -4.071 & -2.406 & 2.660 & 0.273 & 0.003 \\
\hline$-\mathrm{Al} 2 \mathrm{O} 3$ & 1.779 & - & - & - & - & - & -4.102 & -2.332 & 2.610 & 0.275 & 0.005 \\
\hline -LOI & 1.952 & - & - & - & - & - & -5.367 & -3.121 & - & 0.294 & 0.024 \\
\hline$-K 2 O$ & 1.808 & - & - & - & - & - & -5.262 & - & - & 0.334 & 0.064 \\
\hline$-\mathrm{Na} 2 \mathrm{O}$ & 1.466 & - & - & - & - & - & - & - & - & 0.418 & 0.148 \\
\hline
\end{tabular}

Looking at the $\triangle \mathrm{RMS}$ values in the far right column shows us how much the RMS changes when the oxide in the far left column is removed from the regression. It can be seen clearly that $\mathrm{SiO}_{2}$ has a large influence on the model as removing it from the regression results in an increase in $\mathrm{RMS}$ of $0.447 \mathrm{~W} \mathrm{~m}^{-1} \mathrm{~K}^{-1}$. In the same vein it can be seen that $\mathrm{TiO}_{2}, \mathrm{MgO}$ and $\mathrm{CaO}$ all have very little influence and can be left out to no detriment of the model. The bottom half of the table shows the sequential removal of the least sensitive oxide after each new regression. Note that the least sensitive oxide after each new regression does not necessarily correspond to the $\Delta$ RMS values in the top half of the table as the influence of each oxide changes with the removal of others. 
For example, LOI has very little influence on a nine parameter regression but becomes more influential after the removal of $\mathrm{TiO}_{2}, \mathrm{MgO}$ and $\mathrm{CaO}$ to the point where it outweighs the effects of $\mathrm{FeO}$ and $\mathrm{Al}_{2} \mathrm{O}_{3}$ as well. Overall the compositional model performs quite well with only a limited number of oxides included in the regression. Using only the values for $\mathrm{SiO}_{2}, \mathrm{Na}_{2} \mathrm{O}$ and $\mathrm{K}_{2} \mathrm{O}$, I produced a model with a minimal increase in RMS, $0.024 \mathrm{~W} \mathrm{~m}^{-1} \mathrm{~K}^{-1}$, compared to using all nine parameters. A similar analysis was performed to reveal the most influential parameters of the CIPW model (Table 5).

Table 5 - Sensitivities of the model coefficients to CIPW normative minerals. Each column represents the coefficient for a particular model parameter with each row representing a unique regression analysis with one (top half) or more (bottom half) parameters removed. For the top half of the table, the left hand column indicates which individual parameter was left out of the analysis. The bottom half of the table displays results from the cumulative removal of the least sensitive parameter after each step. The parameter indicated in the left hand column is not included in the regression analysis for that row. $\triangle$ RMS is calculated as the new RMS - RMS (all). Qz - quartz; Or - orthoclase; Ab - albite; Cor - corundum; Mt - magnetite; An - anorthite; Di - diopside; En enstatite; Ol - olivine.

\begin{tabular}{|c|c|c|c|c|c|c|c|c|c|c|c|}
\hline & Qz & Or & $A b$ & An & Cor & Di & En & $\mathrm{Ol}$ & $\mathrm{Mt}$ & RMS & $\Delta$ RMS \\
\hline All & 1.700 & 0.850 & 0.673 & 0.682 & 0.588 & 1.063 & 0.938 & 1.053 & 4.422 & 0.271 & \\
\hline \multicolumn{12}{|c|}{ Sensitivity to exclusion of individual mineral } \\
\hline Qz & - & 1.322 & 0.956 & 0.841 & 18.172 & 0.693 & 0.811 & 0.842 & 1.136 & 0.734 & 0.463 \\
\hline Or & 2.051 & - & 0.939 & 0.606 & 0.664 & 0.922 & 1.061 & 1.066 & 5.924 & 0.372 & 0.101 \\
\hline $\mathrm{Ab}$ & 2.086 & 1.337 & - & 0.864 & 2.313 & 1.239 & 0.538 & 0.724 & 17.107 & 0.437 & 0.166 \\
\hline An & 1.819 & 0.773 & 0.773 & - & -4.439 & 1.725 & 1.564 & 1.470 & 2.102 & 0.362 & 0.091 \\
\hline Cor & 1.707 & 0.850 & 0.673 & 0.679 & - & 1.061 & 0.950 & 1.060 & 4.334 & 0.270 & -0.001 \\
\hline $\mathrm{Di}$ & 1.642 & 0.820 & 0.693 & 0.819 & -0.025 & - & 0.521 & 0.941 & 17.333 & 0.310 & 0.039 \\
\hline En & 1.683 & 0.871 & 0.635 & 0.789 & 4.300 & 0.718 & - & 0.765 & 17.745 & 0.315 & 0.044 \\
\hline Ol & 1.625 & 0.856 & 0.588 & 0.879 & 7.362 & 0.810 & 0.147 & - & 20.490 & 0.380 & 0.109 \\
\hline Mt & 1.694 & 0.853 & 0.688 & 0.677 & 0.237 & 1.197 & 1.105 & 1.126 & - & 0.271 & 0.000 \\
\hline \multicolumn{12}{|c|}{ Cumulative sensitivity to mineral exclusion } \\
\hline -Cor & 1.707 & 0.850 & 0.673 & 0.679 & - & 1.061 & 0.950 & 1.060 & 4.334 & 0.270 & -0.001 \\
\hline$-M t$ & 1.697 & 0.853 & 0.688 & 0.676 & - & 1.195 & 1.108 & 1.128 & - & 0.271 & 0.000 \\
\hline$-D i$ & 1.528 & 0.817 & 0.803 & 0.911 & - & - & 1.193 & 1.281 & - & 0.342 & 0.071 \\
\hline -Or & 1.878 & - & 1.055 & 0.818 & - & - & 1.360 & 1.306 & - & 0.402 & 0.131 \\
\hline -En & 1.907 & - & 1.131 & 1.114 & - & - & - & 1.193 & - & 0.471 & 0.200 \\
\hline$-\mathrm{Ol}$ & 1.823 & - & 1.111 & 1.408 & - & - & - & - & - & 0.553 & 0.282 \\
\hline$-A n$ & 1.460 & - & 1.724 & - & - & - & - & - & - & 0.815 & 0.544 \\
\hline$-Q z$ & - & - & 2.146 & - & - & - & - & - & - & 1.090 & 0.819 \\
\hline
\end{tabular}


There are of course some similarities between the sensitivities of the CIPW model parameters and those of the compositional model. The influence of quartz on the model seems to be on par with that of $\mathrm{SiO}_{2}$ which is not unexpected considering one is composed entirely of the other. We can also see that, similar to the less influential oxides, this model could be simplified without significant consequence by removing corundum and magnetite from the regression. This is not surprising considering the relatively low abundance of either of these two minerals. The relatively low influence of diopside and enstatite can be attributed to their compositional relationship with the two least influential oxides $\mathrm{CaO}$ and $\mathrm{MgO}$. In fact, for the top half of the table, the influence of each mineral is almost directly related to the influence of its constituent oxides in Table 4. These relationships are likely attributable to the CIPW algorithm, which assumes idealized mineral chemical compositions to calculate the normative assemblages.

Mineral composition seems to be only one of a number of things that affect the influence of a mineral on the outcome of the model. Other factors being the average abundance per sample, the number of samples in which a mineral is present and cofeaturing minerals. For example, olivine has the third highest influence of the CIPW minerals behind albite and quartz despite its compositional end-members Mg-forsterite and Fe-fayalite. The most likely reason for this is that, due to a mutually exclusive relationship within the CIPW calculations, olivine occurs only in rocks devoid of quartz and of those samples represents an average of $\sim 18 \%$ by volume. It is for a similar reason that albite has the greatest effect on the CIPW model. Not only does its 
composition relate to the two most influential oxides from Table 4, but unlike quartz or olivine, it spans the entire compositional range and is present in almost every sample.

Although the modal mineralogy model, for reasons discussed previously (ie possible inaccurate mode estimations, solid solutions, etc.), did not turn out quite as well as the oxide or CIPW model, it is none the less interesting to examine the model sensitivities (Table 6). Due to assumptions involved in calculating the normative mineralogy, a mineral by mineral comparison is not possible, especially considering the high frequency of hydrous minerals biotite and hornblende in the modal estimates.

Table 6 - Sensitivities of the model coefficients to modal minerals. Each column represents the coefficient for a particular model parameter with each row representing a unique regression analysis with one (top half) or more (bottom half) parameters removed. For the top half of the table, the left hand column indicates which individual parameter was left out of the analysis. The bottom half of the table displays results from the cumulative removal of the least sensitive parameter after each step. The parameter indicated in the left hand column is not included in the regression analysis for that row. $\triangle$ RMS is calculated as the new RMS - RMS (all). Qz - quartz; Or - orthoclase; Plag - plagioclase; Per - perthite; Bt - biotite; Hbl - horblende; Cpx - clinopyroxene; Ol - olivine; Sp - spinel.

\begin{tabular}{|c|c|c|c|c|c|c|c|c|c|c|c|}
\hline & Qz & Or & Plag & Per & $\mathrm{Bt}$ & $\mathrm{Hbl}$ & Cpx & $\mathrm{Ol}$ & Sp & RMS & $\Delta \mathrm{RMS}$ \\
\hline All & 1.411 & 0.780 & 0.876 & 0.829 & -0.081 & 0.669 & 1.050 & -1.931 & 1.049 & 0.435 & \\
\hline \multicolumn{12}{|c|}{ Sensitivity to exclusion of individual mineral } \\
\hline Qz & - & 0.899 & 1.303 & 1.180 & 1.040 & 0.247 & 0.554 & 1.695 & 0.817 & 0.783 & 0.348 \\
\hline Or & 1.762 & - & 0.647 & 0.317 & 3.671 & 1.183 & 1.444 & -4.986 & 1.132 & 0.766 & 0.331 \\
\hline Plag & 2.105 & 0.641 & - & 0.443 & 1.353 & 1.358 & 2.168 & -10.238 & 1.493 & 0.737 & 0.302 \\
\hline Per & 1.743 & 0.610 & 0.650 & - & 2.444 & 0.648 & 1.407 & -4.667 & 1.141 & 0.657 & 0.222 \\
\hline Bt & 1.407 & 0.776 & 0.873 & 0.821 & - & 0.665 & 1.056 & -1.974 & 1.050 & 0.437 & 0.002 \\
\hline $\mathrm{Hbl}$ & 1.349 & 0.815 & 0.938 & 0.826 & 0.147 & - & 1.078 & -2.272 & 0.982 & 0.467 & 0.032 \\
\hline Cpx & 1.254 & 0.822 & 1.093 & 0.947 & -0.679 & 0.728 & - & 6.868 & 1.193 & 0.563 & 0.128 \\
\hline Ol & 1.401 & 0.783 & 0.890 & 0.836 & -0.122 & 0.675 & 0.976 & - & 0.979 & 0.440 & 0.005 \\
\hline Sp & 1.387 & 0.783 & 0.904 & 0.839 & -0.101 & 0.623 & 1.097 & 0.755 & - & 0.477 & 0.042 \\
\hline \multicolumn{12}{|c|}{ Cumulative sensitivity to mineral exclusion } \\
\hline$-B t$ & 1.407 & 0.776 & 0.873 & 0.821 & - & 0.665 & 1.056 & -1.974 & 1.050 & 0.437 & 0.002 \\
\hline$-\mathrm{Ol}$ & 1.396 & 0.777 & 0.886 & 0.825 & - & 0.669 & 0.982 & - & 0.977 & 0.443 & 0.008 \\
\hline$-\mathrm{Hbl}$ & 1.340 & 0.823 & 0.958 & 0.844 & - & - & 0.986 & - & 0.900 & 0.471 & 0.036 \\
\hline$-S p$ & 1.336 & 0.821 & 0.962 & 0.845 & - & - & 1.127 & - & - & 0.499 & 0.064 \\
\hline -Cpx & 1.095 & 0.840 & 1.228 & 0.928 & - & - & - & - & - & 0.689 & 0.254 \\
\hline -Plag & 2.226 & 0.834 & - & 0.554 & - & - & - & - & - & 0.811 & 0.376 \\
\hline$-Q z$ & - & 1.151 & - & 1.293 & - & - & - & - & - & 0.988 & 0.553 \\
\hline -Or & - & - & - & 1.311 & - & - & - & - & - & 0.964 & 0.529 \\
\hline
\end{tabular}


Although still the most influential mineral, quartz does not have the same level of effect as seen in the CIPW model. In fact, the model's sensitivity to plagioclase and orthoclase is almost on par with that of quartz. Evidence for this relatively equal sensitivity can be seen in the high degree of randomness of thermal conductivity values distributed between the three minerals (Figure 3c). Considering perthite, the fourth most influential parameter, is a mixture of plagioclase and potassium feldspar, it becomes evident that the role of feldspars in this model is a significant one. This is not unlike the results of the CIPW sensitivities where the feldspars played a similar influential role in the outcome of the model. One thing to note between the models is that orthoclase appears to have a larger effect in terms of modal mineralogy during cumulative removals of parameters (Table 6- lower). This is likely due to the way in which the CIPW algorithm systematically underestimates the proportion of orthoclase (Figure 3b). Curiously, modelling conductivity based on orthoclase and perthite alone ( $\triangle \mathrm{RMS} 0.529)$ appears to produce a better result than a model involving quartz as well ( $\triangle \mathrm{RMS} 0.553)$. Biotite and olivine appear to have little effect on the outcome of the model while clinopyroxene seems to be a controlling factor at least in the quartz-deficient samples.

\section{Relating thermal conductivity to other physical properties}

\section{THERMAL CONDUCTIVITY AND P-WAVE VELOCITY}

Composition is a major control on the physical properties of many minerals and rocks. In establishing a relationship between thermal conductivity and major oxide composition, it becomes possible to relate conductivity to other petrophysical properties that relate to composition. Behn and Kelemen (2003) perform thermodynamic calculations on a synthetic dataset of igneous compositions to calculate mineral 
assemblages and from that estimate p-wave velocity. Using these calculations, the authors developed an empirical estimate for P-wave velocity as a function of major oxide composition. Their model was then tested against 139 laboratory measurements of $\mathrm{P}$-wave and compositional data to determine an uncertainty of $0.13 \mathrm{~km} \mathrm{~s}^{-1}$ across all temperature and pressure conditions. Estimates of P-wave velocities using the compositional data from this study reveal a correlation with thermal conductivity (Figure 9). As p-wave velocity increases, thermal conductivity rapidly decreases from $\sim 5.8$ to $6.3 \mathrm{~km} \mathrm{~s}^{-1}$ before plateauing at $\sim 2.4 \mathrm{~W} \mathrm{~m} \mathrm{~K}^{-1} \mathrm{~K}^{-1}$ for velocities $>6 \mathrm{~km} \mathrm{~s}^{-1}$.

This trend occurs through the entire distribution of granite and likely relates directly to the amount of quartz present in the samples. After an initial rapid decrease, conductivity continues to decrease steadily through both the distribution of diorite and gabbroic

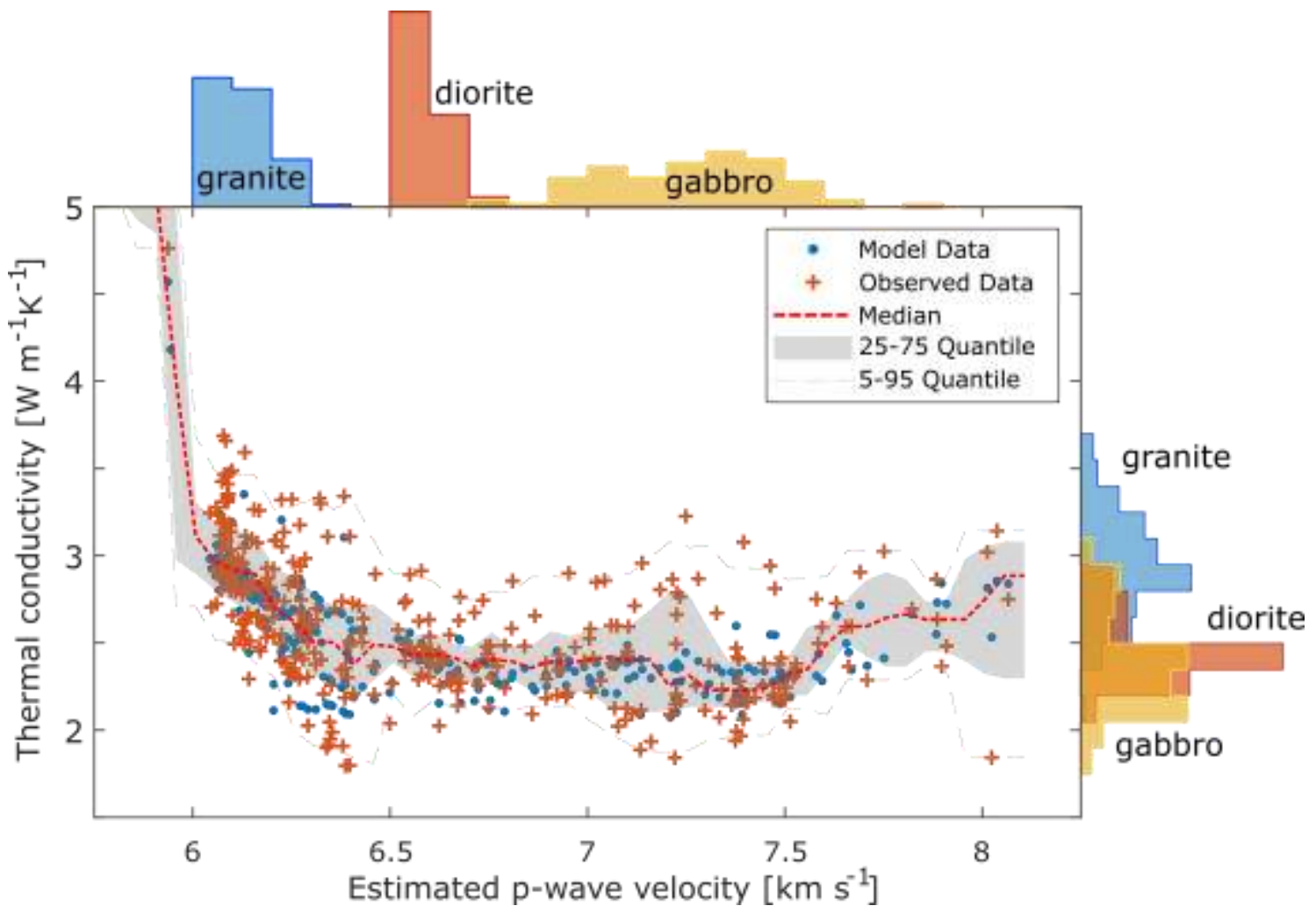

Figure 9 - Relationship between thermal conductivity and estimated p-wave velocity. The histogram on top represents the probability distribution of estimated p-wave velocity for granite (blue), diorite (red) and gabbro (yellow). The horizontal histogram (right) represents the probability distribution of observed thermal conductivity values for granite, diorite and gabbro. The median line is a running average calculated every $0.05 \mathrm{~km} \mathrm{~s}^{-1}$ over a bin width of $0.2 \mathrm{~km} \mathrm{~s}^{-1}$ 
samples. This region presumably relates to a drastic decrease in the amount of quartz present and consequent increase in feldspars and mafics. During this feldspar dominant region, the median thermal conductivity may possibly reflect a change in composition from alkali feldspar $\left(2.37 \mathrm{~W} \mathrm{~m}^{-1} \mathrm{~K}^{-1}\right)$ dominant assemblages to plagioclase dominant $\left(2.2 \mathrm{~W} \mathrm{~m}^{-1} \mathrm{~K}^{-1}\right)$. There is of course a large amount of scatter around the median line which is likely due to compositional variation within the samples or the result of undetected defects (Schön, 2015). As p-wave velocity increases above $7.5 \mathrm{~km} \mathrm{~s}^{-1}$, conductivity begins to increase slightly. This relates to the increasing maficity of the samples and the transition from gabbro to ultramafics.

\section{THERMAL CONDUCTIVITY AND DENSITY}

For granitic rocks there appears to be a large amount of scatter and a less clear relationship between thermal conductivity and density. The moving average curve suggests a slight negative trend through this region (Figure 10). This results likely from the high variability in quartz content, which has both low density and high thermal conductivity. As composition changes from granite to diorite and eventually gabbro, there is a steady decrease in conductivity as density increases up to $\sim 3000 \mathrm{~kg} \mathrm{~m}^{-3}$. This is consistent with known relationships between thermal conductivity and composition where density increases and thermal conductivity decreases from felsic to mafic (Schön, 2015). Above $3000 \mathrm{~kg} \mathrm{~m}^{-3}$, composition changes from mafic to ultramafic and thermal conductivity begins to steadily increase. This trend is consistent with the results of Sundberg et al. (2009) who showed that a change in chemical composition of plagioclase (from albite to anorthite) and olivine (from fayalite to forsterite) from mafic to ultramafic resulted in increased thermal conductivity. 


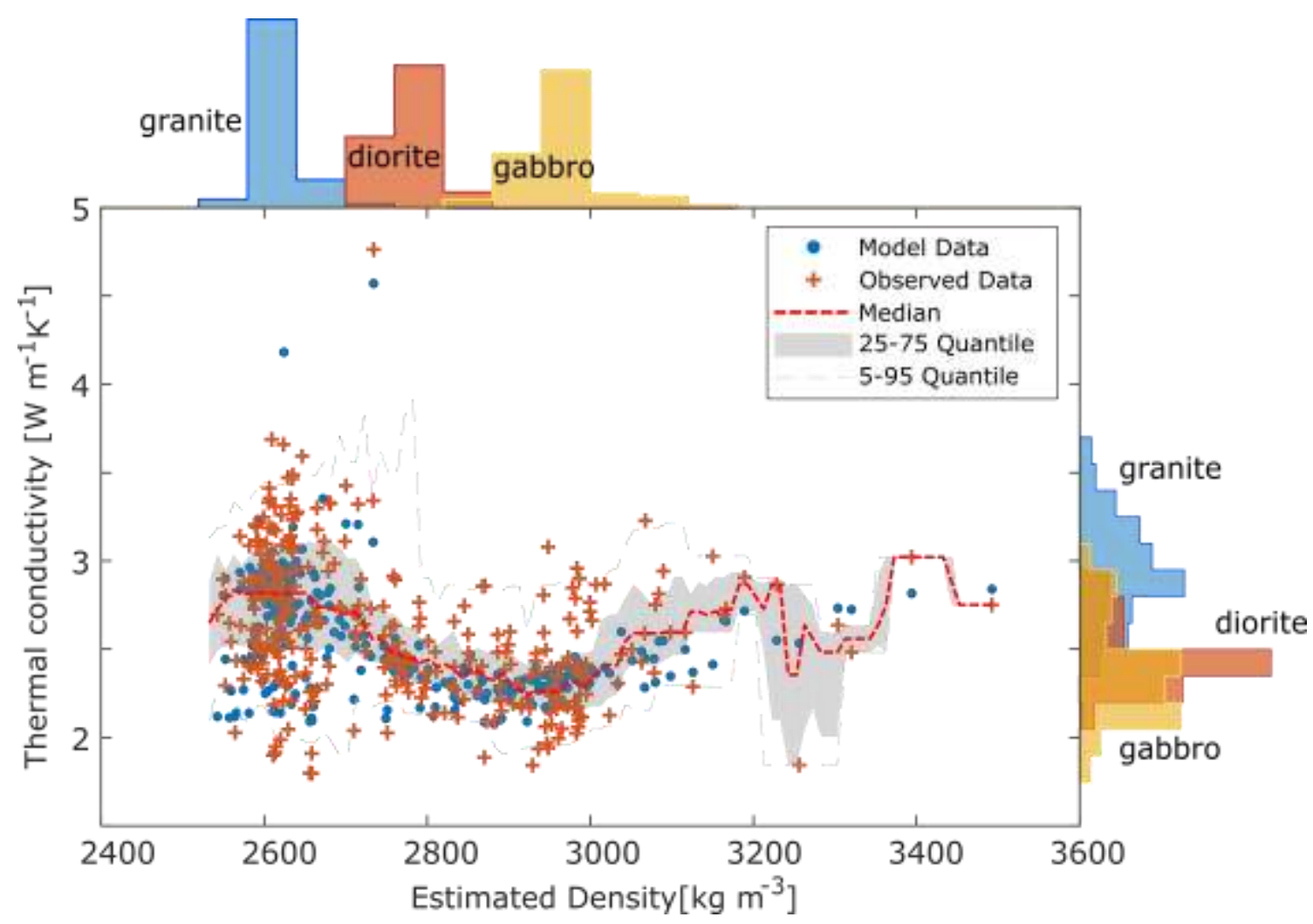

Figure 10 -Relationship between thermal conductivity and estimated density. The histogram on top represents the probability distribution of estimated p-wave velocity for granite (blue), diorite (red) and gabbro (yellow). The horizontal histogram (right) represents the probability distribution of observed thermal conductivity values for granite, diorite and gabbro. The median line is a running average calculated every $10 \mathrm{~kg} \mathrm{~m}^{-3}$ over a bin width of $100 \mathrm{~kg} \mathrm{~m}^{-3}$.

\section{The forward model}

The forward mineralogy model unexpectedly performed far worse than the inverse models (Table 3), most likely due to a number of simplifying assumptions and unquantified errors involved in calculating the mineral modes and deriving mineral conductivity values. For the purpose of simplification, the effect of any solid solution series was not considered and an average conductivity value was assigned to the mineral group. For example, olivine was assigned a value of $4.08 \mathrm{~W} \mathrm{~m}^{-1} \mathrm{~K}^{-1}$, the geometric mean of its two end-members fayalite $\left(3.39 \mathrm{~W} \mathrm{~m}^{-1} \mathrm{~K}^{-1}\right)$ and forsterite $\left(4.91 \mathrm{~W} \mathrm{~m}^{-1} \mathrm{~K}^{-1}\right)$. In doing this, estimated rock conductivity could differ significantly from observed conductivity depending on the actual composition of olivine. A similar simplification 
was made with plagioclase and its end-members albite and anorthite which may have also had an effect on estimated conductivity. Despite the limitations of the model, I believe it could prove effective with more intimate knowledge of the mineralogy of the samples.

\section{Implications for current and future research}

Current and future research into thermal geophysics will benefit immensely from the ability to obtain accurate estimates of thermal conductivity without the need for time consuming or costly laboratory analysis. A model based on major oxide composition means any data set containing compositional analysis can now be used to produce accurate thermal conductivity estimates with little effort. The flow on effect of more accurate conductivity estimates will hopefully lead to improved heat flow models and temperature profiles. Spatially sparse data sets will also benefit from the ability to complement measured conductivity with estimates derived from compositional sources.

To follow up on these results, future research should be directed towards developing similar models for both sedimentary and metamorphic rock types. A sedimentary model would ideally take into account the effect of porosity and pore fluid in combination with the major oxide composition while a metamorphic equivalent would allow for the effects of anisotropy. With these two additional models, accurate prediction of thermal conductivity would become possible anywhere major oxide composition can be measured. 


\section{CONCLUSIONS}

The preferred thermal conductivity model uses major oxide composition $\left(\mathrm{SiO}_{2}, \mathrm{Al}_{2} \mathrm{O}_{3}\right.$, $\mathrm{FeO}, \mathrm{Na}_{2} \mathrm{O}, \mathrm{K}_{2} \mathrm{O}$ and $\left.\mathrm{LOI}\right)$ to predict thermal conductivity for a representative range of plutonic rock types to within $0.27 \mathrm{~W} \mathrm{~m}^{-1} \mathrm{~K}^{-1}$ by

$$
\begin{aligned}
K_{e f f}=\exp ( & 1.729 \mathrm{C}_{\mathrm{SiO}_{2}}+-0.253 \mathrm{C}_{\mathrm{Al}_{2} \mathrm{O}_{3}}+1.054 \mathrm{C}_{\mathrm{FeO}} \\
& \left.+-3.831 \mathrm{C}_{\mathrm{Na}_{2} \mathrm{O}}+-1.622 \mathrm{C}_{\mathrm{K}_{2} \mathrm{O}}+1.737 \mathrm{C}_{\mathrm{LOI}}\right)
\end{aligned}
$$

where $\mathrm{C}$ is the weight percentage of the indicated oxide. The dominant compositional control on thermal conductivity is $\mathrm{SiO}_{2}$, owing to its comparatively high abundance per sample in relation to the other oxides and its presence through the entire compositional range. The rapid increases in thermal conductivity from $\sim 60 \% \mathrm{SiO}_{2}$ is the result of growing quartz content due to its exceptionally high thermal conductivity with respect to most common igneous minerals.

The major oxide model performed better than the estimated mineralogy model due to over-simplicity of the latter. Failure to identify and take into account the varied thermal conductivity of solid solution mineral series was the most likely cause for the discrepancy between the models. The geometric mean produced the tightest fit on observed data although the square-root could be used interchangeably to minimal detriment of the model.

Comparison of the relationships between thermal conductivity and both p-wave velocity and density saw systematic trends in each related directly to variations in composition. For p-wave velocity, thermal conductivity decreases rapidly with changing composition 
from felsic to intermediate compositions at $\sim 6.5 \mathrm{~km} \mathrm{~s}^{-1}$. Continuing towards more mafic compositions, a slight decreasing trend is evident from $6.5 \mathrm{~km} \mathrm{~s}^{-1}$ to $7.5 \mathrm{~km} \mathrm{~s}^{-1}$ before thermal conductivity steadily increases again with velocities $>7.5 \mathrm{~km} \mathrm{~s}^{-1}$. A similar trend is observed between thermal conductivity and density where an initial decreasing trend is observed between 2600 to $2900 \mathrm{~kg} \mathrm{~m}^{-3}$ before thermal conductivity starts to increase steadily with increasing density.

The establishment of this model should pave the way for future research into the relationship of thermal conductivity and major oxide composition. Emphasis should be placed on investigating the combined effect of major oxide composition and anisotropy in metamorphic rocks and also major oxide composition and porosity for sedimentary rock types. The compositionally based relationship between thermal conductivity, pwave velocity and density should be explored further using laboratory data for each property.

\section{ACKNOWLEDGMENTS}

My eternal gratitude goes out to my supervisor Derrick Hasterok whose constant support and guidance throughout the year has been unending. Thankyou to Justin Payne at the University of South Australia who generously loaned samples and unpublished chemistry data for the betterment of this thesis. Thankyou to Betina Bendall at the SA Department of State Development who, despite a busy schedule, took the time to help navigate the depths of SARIG. To Keryn and David Groom (and the rest of the team) at the SA Drill Core Library, thankyou for accommodating an unorganised student at such short notice. Thankyou to Tony Milnes for your generous help in navigating the Mawson Crypts that you so tirelessly organise. Last but not least, thankyou to Alec Walsh for the training and support provided to myself and all Honours students throughout the year. 


\section{REFERENCES}

Arganda-Carreras, I., Kaynig, V., Rueden, C., Eliceiri, K. W., Schindelin, J., Cardona, A., \& Sebastian Seung, H. (2017). Trainable Weka Segmentation: a machine learning tool for microscopy pixel classification. Bioinformatics, 33(15), 2424-2426. doi:10.1093/bioinformatics/btx180

Aster, R. C., Borchers, B., \& Thurber, C. H. (2013). Chapter Two - Linear Regression. In Parameter Estimation and Inverse Problems (Second Edition) (pp. 25-53). Boston: Academic Press.

Beardsmore, G. R., \& Cull, J. P. (2001). Crustal heat flow: a guide to measurement and modelling: Cambridge University Press.

Behn, M. D., \& Kelemen, P. B. (2003). Relationship between seismic P-wave velocity and the composition of anhydrous igneous and meta-igneous rocks. Geochemistry, Geophysics, Geosystems, 4(5), n/a-n/a. doi:10.1029/2002GC000393

Birch, A. F., \& Clark, H. (1940). The thermal conductivity of rocks and its dependence upon temperature and composition. American Journal of Science, 238(8), 529-558.

Blumm, J., \& Lemarchand, S. (2002). Influence of test conditions on the accuracy of laser flash measurements. High Temperatures. High Pressures, 34(5), 523528.

Brigaud, F., \& Vasseur, G. (1989). Mineralogy, porosity and fluid control on thermal conductivity of sedimentary rocks. Geophysical Journal International, 98(3), 525-542. doi:10.1111/j.1365-246X.1989.tb02287.x

Cermak, V., \& Rybach, L. (1982). Thermal conductivity and specific heat of minerals and rocks. Landolt-Bornstein; Zahlenwerte und Funktionen aus Naturwissenschaften und Technik, 305-343.

Chekhonin, E., Parshin, A., Pissarenko, D., Popov, Y., Romushkevich, R., Safonov, S., . . Stenin, V. P. (2012). When rocks get hot: thermal properties of reservoir rocks. Oilfield Review, 24(3), 20-37.

Clauser, C. (2006). Geothermal energy. Landolt-Börnstein, group VIII: advanced materials and technologies, 3, 493-604.

Clauser, C. (2009). Heat transport processes in the Earth's crust. Surveys in Geophysics, 30(3), 163-191.

Clauser, C. (2011). Thermal storage and transport properties of rocks, II: thermal conductivity and diffusivity. In Encyclopedia of solid earth geophysics (pp. 1431-1448): Springer.

Clauser, C., \& Huenges, E. (1995). Thermal conductivity of rocks and minerals. Rock physics \& phase relations: a handbook of physical constants, 105-126.

Davis, M. G., Chapman, D. S., Van Wagoner, T. M., \& Armstrong, P. A. (2007). Thermal conductivity anisotropy of metasedimentary and igneous rocks. Journal of Geophysical Research: Solid Earth, 112(B5), n/a-n/a. doi:10.1029/2006JB004755

Diment, W. H., \& Pratt, H. R. (1988). Thermal conductivity of some rock-forming minerals: A tabulation: Citeseer. 
Dreyer, W. (1974). Properties of Anisotropic Solid-State Materials: Thermal and Electric Properties. In: Springer, Wien.

Esteban, L., Pimienta, L., Sarout, J., Piane, C. D., Haffen, S., Geraud, Y., \& Timms, N. E. (2015). Study cases of thermal conductivity prediction from P-wave velocity and porosity. Geothermics, 53(Supplement C), 255-269. doi:https://doi.org/10.1016/i.geothermics.2014.06.003

Fuchs, S., \& Förster, A. (2014). Well-log based prediction of thermal conductivity of sedimentary successions: a case study from the North German Basin. Geophysical Journal International, 196(1), 291-311. doi:10.1093/gji/ggt382

Fuchs, S., Schütz, F., Förster, H.-J., \& Förster, A. (2013). Evaluation of common mixing models for calculating bulk thermal conductivity of sedimentary rocks: Correction charts and new conversion equations. Geothermics, 47(Supplement C), 40-52. doi:https://doi.org/10.1016/j.geothermics.2013.02.002

Gegenhuber, N., \& Schoen, J. (2012). New approaches for the relationship between compressional wave velocity and thermal conductivity. Journal of Applied Geophysics, 76(Supplement C), 50-55. doi:https://doi.org/10.1016/j.jappgeo.2011.10.005

Gu, Y., Rühaak, W., Bär, K., \& Sass, I. (2017). Using seismic data to estimate the spatial distribution of rock thermal conductivity at reservoir scale. Geothermics, 66, 61-72.

Hartmann, A., Rath, V., \& Clauser, C. (2005). Thermal conductivity from core and well log data. International Journal of Rock Mechanics and Mining Sciences, 42(7), 1042-1055.

Hasterok, D., \& Webb, J. (2017). On the radiogenic heat production of igneous rocks. Geoscience Frontiers, 8(5), 919-940. doi:https://doi.org/10.1016/j.gsf.2017.03.006

Hofmeister, A. M. (2007). Thermal conductivity of the Earth's deepest mantle. In Superplumes: Beyond Plate Tectonics (pp. 269-292): Springer.

Hofmeister, A. M., \& Pertermann, M. (2008). Thermal diffusivity of clinopyroxenes at elevated temperature. European Journal of Mineralogy, 20(4), 537-549. doi:10.1127/0935-1221/2008/0020-1814

Hollocher, K. (2004). CIPW Norm Calculation Program. Geology Department, Union College.

Horai, K.-i. (1971). Thermal conductivity of rock-forming minerals. Journal of Geophysical Research, 76(5), 1278-1308.

Horai, K.-i., \& Susaki, J.-i. (1989). The effect of pressure on the thermal conductivity of silicate rocks up to $12 \mathrm{kbar}$. Physics of the Earth and Planetary Interiors, 55(3), 292-305. doi:https://doi.org/10.1016/0031-9201(89)90077-0

Kukkonen, I. T., \& Peltoniemi, S. (1998). Relationships between thermal and other petrophysical properties of rocks in Finland. Physics and Chemistry of the Earth, 23(3), 341-349. doi:https://doi.org/10.1016/S00791946(98)00035-4

Middlemost, E. A. (1994). Naming materials in the magma/igneous rock system. Earth-Science Reviews, 37(3-4), 215-224.

Mielke, P., Bär, K., \& Sass, I. (2017). Determining the relationship of thermal conductivity and compressional wave velocity of common rock types as a 
basis for reservoir characterization. Journal of Applied Geophysics, 140, 135144. doi:https://doi.org/10.1016/i.jappgeo.2017.04.002

Parker, W., Jenkins, R., Butler, C., \& Abbott, G. (1961). Flash method of determining thermal diffusivity, heat capacity, and thermal conductivity. Journal of applied physics, 32(9), 1679-1684.

Pimienta, L., Sarout, J., Esteban, L., \& Piane, C. D. (2014). Prediction of rocks thermal conductivity from elastic wave velocities, mineralogy and microstructure. Geophysical Journal International, 197(2), 860-874.

Popov, Y., Tertychnyi, V., Romushkevich, R., Korobkov, D., \& Pohl, J. (2003). Interrelations between thermal conductivity and other physical properties of rocks: experimental data. Thermo-Hydro-Mechanical Coupling in Fractured Rock, 1137-1161.

Popov, Y. A., Pribnow, D. F., Sass, J. H., Williams, C. F., \& Burkhardt, H. (1999). Characterization of rock thermal conductivity by high-resolution optical scanning. Geothermics, 28(2), 253-276.

Pribnow, D., \& Umsonst, T. (1993). Estimation of thermal conductivity from the mineral composition: Influence of fabric and anisotropy. Geophysical research letters, 20(20), 2199-2202.

Sass, J., Lachenbruch, A. H., Moses, T., \& Morgan, P. (1992). Heat flow from a scientific research well at Cajon Pass, California. Journal of Geophysical Research: Solid Earth, 97(B4), 5017-5030.

Schindelin, J., Arganda-Carreras, I., Frise, E., Kaynig, V., Longair, M., Pietzsch, T., ... Schmid, B. (2012). Fiji: an open-source platform for biological-image analysis. Nature methods, 9(7), 676-682.

Schneider, C. A., Rasband, W. S., \& Eliceiri, K. W. (2012). NIH Image to ImageJ: 25 years of image analysis. Nature methods, 9(7), 671-675.

Schön, J. H. (2015). Physical properties of rocks: Fundamentals and principles of petrophysics (Vol. 65): Elsevier.

Seipold, U. (1998). Temperature dependence of thermal transport properties of crystalline rocks-a general law. Tectonophysics, 291(1), 161-171.

Streckeisen, A. (1974). Classification and nomenclature of plutonic rocks recommendations of the IUGS subcommission on the systematics of igneous rocks. Geologische Rundschau, 63(2), 773-786.

Sundberg, J., Back, P.-E., Ericsson, L. O., \& Wrafter, J. (2009). Estimation of thermal conductivity and its spatial variability in igneous rocks from in situ density logging. International Journal of Rock Mechanics and Mining Sciences, 46(6), 1023-1028. doi:https://doi.org/10.1016/j.ijrmms.2009.01.010

Vasseur, G., Brigaud, F., \& Demongodin, L. (1995). Thermal conductivity estimation in sedimentary basins. Tectonophysics, 244(1), 167-174. doi:https://doi.org/10.1016/0040-1951(94)00225-X

Von Herzen, R., \& Maxwell, A. (1959). The measurement of thermal conductivity of deep-sea sediments by a needle-probe method. Journal of Geophysical Research, 64(10), 1557-1563.

Vosteen, H.-D., \& Schellschmidt, R. (2003). Influence of temperature on thermal conductivity, thermal capacity and thermal diffusivity for different types of rock. Physics and Chemistry of the Earth, Parts A/B/C, 28(9), 499-509. 
Williams, C. F., \& Anderson, R. N. (1990). Thermophysical properties of the Earth's crust: In situ measurements from continental and ocean drilling. Journal of Geophysical Research: Solid Earth, 95(B6), 9209-9236.

doi:10.1029/JB095iB06p09209 


\section{APPENDIX A: SAMPLE LIST}

The majority of samples were sourced from collections used in past Honours and $\mathrm{PhD}$ theses completed at the University of Adelaide. One collection was loaned by Justin Payne at the University of South Australia while the remainder came from the South Australian Drill Core Library. Corresponding chemical data for these collections were either received via personal communications or accessed online via the South Australian Mineral Resources Gateway. Name are based on the total alkali silica classification scheme after Middlemost (2004).

References are as follows:

1. Robinson, F. A. (2014). Geochronological and geochemical constraints on the lithospheric evolution of the Arabian Shield: Understanding plutonic rock petrogenesis in accretionary orogeny, University of Adelaide, Adelaide, SA.

2. Payne, J. (2017). Personal Communications

3. Kromkhun, K. (2010). Petrogenesis of high heat producing granite: implication for Mt Painter Province, South Australia. (Doctor of Philosophy), University of Adelaide, Adelaide, SA.

4. Ogasawara, M. (1996). Petrology of Early Proterozoic granitoids in the Halls Creek mobile zone. (Doctor of Philosophy), University of Adelaide, Adelaide, SA.

5. $\quad$ SA Drill Core Library (2017). Personal Communications

6. Christodoulou, C. C. (1992). Petrology of the plutonic rocks of the Macquarie Island Complex. (Doctor of Philosophy), University of Adelaide, Adelaide,SA.

7. Knight, J. M. (1997). Petrogenesis of the western St Peter Suite, western Gawler Craton, South Australia - a petrological, geochemical and isotopic investigation. (Bachelor of Science (Hons)), University of Adelaide, Adelaide, SA.

8. Neumann, N. L. (2001). Geochemical and isotopic characteristics of South Australian Proterozoic granites: implications for the origin and evolution of high heatproducing terrains. (Bachelor of Science (Hons)), University of Adelaide, Adelaide, SA.

9. Brett, D. (1998). Structural, geochemical and isotopic investigation of granitoids within the central area of the eastern Weekeroo Inlier, Olary Domain, South Australia. (Bachelor of Science (Honours)), University of Adelaide, Adelaide, SA.

10. Dove, M. B. (1997). The geology, petrology, geochemistry and isotope geology of the eastern St Peter Suite, western Gawler Craton, South Australia. (Bachelor of Science (Hons)), University of Adelaide, Adelaide, SA.

11. Hoesni, M. J. (1985). The granitoids and migmatites of the Monarto area, South Australia. (Bachelor of Science (Hons)), University of Adelaide, Adelaide, SA.

12. Henstridge, D. A. (1970). The petrology and geochemistry of the upper south-east granites, South Australia. (Bachelor of Science (Hons), University of Adelaide, Adelaide, SA.

13. Johnson, G. I. (1991). The petrology, geochemistry and geochronology of the felsic alkaline suite of the eastern Yilgarn Block, Western Australia. (Doctor of Philosophy), University of Adelaide, Adelaide, SA. 
* Indicates modal estimate reported by original researcher Sample FR-aa168

FR-abg172

FR-abg173

FR-abg179

FR-abg180

FR-ad194

FR-ad195

FR-ad196

FR-ad197

FR-ao101

FR-ao83

FR-ao85

FR-ao87

FR-ao98

FR-ay186

FR-dm01a

FR-dm01b

FR-dm01c

FR-hla110

FR-hla111

FR-hla112

FR-hn162

FR-hwg03

FR-hwg07

FR-hwg09

FR-id155

FR-id156

FR-id159

FR-id163

FR-ih66

FR-ih73

FR-ih74

FR-ih76

FR-kg142

FR-kg145

FR-kg150

FR-ku121

FR-ku123

FR-ku139

FR-kw13

FR-kw15

FR-kw16

Reference

Granite

Granite

Granite

Granite

Granite

Syenite

Syenite

Syenite

Syenite

Dacite

Granite

Granite

Subalkalic Gabbro

Granodiorite

Andesite

Gabbroic Diorite

Subalkalic Gabbro

Granodiorite

Quartz Monzonite

Granite

Granite

Rhyolite

Granite

Granite

Granite

Granite

Granite

Granite

Granite

Granite

Granite

Granite

Granite

Granite

Granite

Granite

Granite

Granite

Granite

Granite

Alkalic Gabbro

Alkalic Gabbro
TAS name
Modal

Chemistry CIPW Mineralog
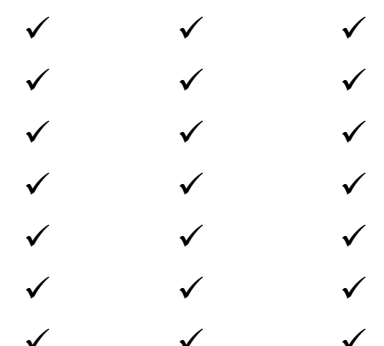

$\checkmark$

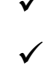

$\checkmark$

$\checkmark$

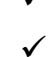

$\checkmark$

$\checkmark$
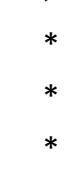

$\checkmark$
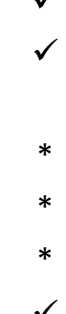

$\checkmark$

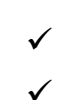

$\checkmark$
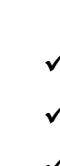

$\checkmark$

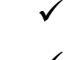

$\checkmark$
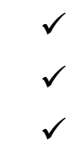

$\checkmark$

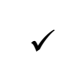

$\checkmark$

$\checkmark$

$\checkmark$
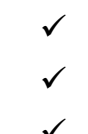

$\mathrm{k}$

$\left(\mathrm{W} \mathrm{m}^{-1} \mathrm{~K}^{-1}\right) \quad\left(\mathrm{W} \mathrm{m}^{-1} \mathrm{~K}^{-1}\right)$

$2.95 \quad 0.12$

$3.04 \quad 0.08$

$3.19 \quad 0.07$

$2.91 \quad 0.06$

$3.12 \quad 0.06$

$1.95 \quad 0.03$

$1.90 \quad 0.03$

$1.99 \quad 0.03$

$1.91 \quad 0.02$

$2.59 \quad 0.02$

$3.41 \quad 0.06$

$3.35 \quad 0.05$

$2.59 \quad 0.04$

$2.38 \quad 0.04$

$2.90 \quad 0.05$

$2.58 \quad 0.05$

$2.19 \quad 0.03$

$2.49 \quad 0.04$

$2.35 \quad 0.04$

$2.82 \quad 0.07$

$2.50 \quad 0.07$

$3.47 \quad 0.05$

$3.33 \quad 0.05$

$2.45 \quad 0.09$

$\begin{array}{ll}2.80 & 0.07\end{array}$

$\begin{array}{ll}2.87 & 0.19\end{array}$

$3.03 \quad 0.14$

$3.18 \quad 0.12$

$3.19 \quad 0.12$

$2.94 \quad 0.07$

$2.79 \quad 0.06$

$2.93 \quad 0.05$

$2.87 \quad 0.06$

$2.67 \quad 0.05$

$2.63 \quad 0.05$

$2.84 \quad 0.04$

$2.83 \quad 0.08$

$2.85 \quad 0.13$

$2.53 \quad 0.03$

$3.31 \quad 0.18$

$2.21 \quad 0.03$

$2.15 \quad 0.04$ 
* Indicates modal estimate reported by original researcher Sample FR-kw18

FR-kw19

FR-kw21

FR-kw22

FR-kw23

FR-kw29

FR-kw31

FR-kw32

FR-kw36

FR-kw38

FR-kw40

FR-kw41

FR-kw45

FR-kw46

FR-kw50

FR-ky124

FR-ky125

FR-ky126

FR-ky129

FR-ky130

FR-md93

FR-md95

FR-mr189

FR-mr190

FR-mr191

FR-mu131

FR-mu132

FR-nr117

FR-nr119

FR-rt181

FR-rt183

FR-rt185

FR-su214

FR-su215

FR-wb61

FR-wb62

FR-wb63

FR-wb65

JP-D525001

JP-D525006

JP-D525007

JP-D525011

\begin{tabular}{|c|c|}
\hline Reference & TAS name \\
\hline 1 & Peridotgabbro \\
\hline 1 & Subalkalic Gabbro \\
\hline 1 & Granite \\
\hline 1 & Granite \\
\hline 1 & Granite \\
\hline 1 & Granite \\
\hline 1 & Granite \\
\hline 1 & Monzonite \\
\hline 1 & Granite \\
\hline 1 & Granite \\
\hline 1 & Granite \\
\hline 1 & Granite \\
\hline 1 & Granite \\
\hline 1 & Granite \\
\hline 1 & Granite \\
\hline 1 & Rhyolite \\
\hline 1 & Rhyolite \\
\hline 1 & Rhyolite \\
\hline 1 & Quartz Monzonite \\
\hline 1 & Quartz Monzonite \\
\hline 1 & Granite \\
\hline 1 & Granite \\
\hline 1 & Syenite \\
\hline 1 & Syenite \\
\hline 1 & Syenite \\
\hline 1 & Basaltic Trachyandesite \\
\hline 1 & Basaltic Trachyandesite \\
\hline 1 & Granite \\
\hline 1 & Granite \\
\hline 1 & Gabbroic Diorite \\
\hline 1 & Diorite \\
\hline 1 & Gabbroic Diorite \\
\hline 1 & Granodiorite \\
\hline 1 & Granodiorite \\
\hline 1 & Granite \\
\hline 1 & Granite \\
\hline 1 & Granite \\
\hline 1 & Granite \\
\hline 2 & Peridotgabbro \\
\hline 2 & Subalkalic Gabbro \\
\hline 2 & Subalkalic Gabbro \\
\hline 2 & Granite \\
\hline
\end{tabular}

Modal Chemistry CIPW Mineralog

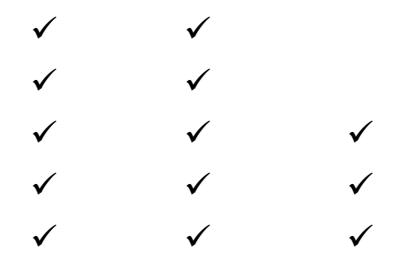

$\sigma$

$\left(\mathrm{W} \mathrm{m}^{-1} \mathrm{~K}^{-1}\right) \quad\left(\mathrm{W} \mathrm{m}^{-1} \mathrm{~K}^{-1}\right)$

$2.41 \quad 0.03$

$2.07 \quad 0.03$

$3.47 \quad 0.20$

$3.35 \quad 0.08$

$3.14 \quad 0.09$

$3.17 \quad 0.06$

$3.31 \quad 0.05$

$2.55 \quad 0.03$

$2.96 \quad 0.05$

$2.89 \quad 0.05$

$2.96 \quad 0.07$

$2.95 \quad 0.07$

$2.81 \quad 0.06$

$2.99 \quad 0.05$

$2.82 \quad 0.04$

$2.73 \quad 0.05$

$\begin{array}{ll}2.53 & 0.07\end{array}$

$2.59 \quad 0.04$

$2.21 \quad 0.03$

$2.05 \quad 0.02$

$\begin{array}{ll}2.82 & 0.04\end{array}$

$2.67 \quad 0.04$

$1.80 \quad 0.03$

$1.80 \quad 0.03$

$\begin{array}{ll}1.91 & 0.02\end{array}$

$2.48 \quad 0.05$

$2.67 \quad 0.04$

$2.49 \quad 0.05$

$2.56 \quad 0.07$

$2.48 \quad 0.03$

$\begin{array}{ll}2.75 & 0.05\end{array}$

$2.86 \quad 0.05$

$2.56 \quad 0.03$

$2.71 \quad 0.03$

$2.86 \quad 0.11$

$3.26 \quad 0.13$

$2.82 \quad 0.05$

$3.11 \quad 0.13$

$2.87 \quad 0.07$

$2.60 \quad 0.07$

$2.79 \quad 0.05$

$\begin{array}{ll}3.09 & 0.08\end{array}$ 
* Indicates modal estimate reported by original researcher

\section{Sample}

JP-D525012

JP-D525014

JP-D525015

JP-D525016

JP-D525017

JP-D525018

JP-D525028

JP-D525036

JP-D525038

JP-D525041

JP-D525042

JP-D525046

JP-D525048

JP-D525049

JP-D525051

JP-D525057

JP-D525064

JP-D525087

JP-D525088

JP-D525090

JP-D525109

JP-D525117

JP-D525118

JP-D525119

JP-D525130

JP-D525138

JP-D525140

JP-D525144

JP-D525151

JP-D525152

JP-D525156

JP-D525205

JP-D525207

JP-D525210

JP-D525212

JP-D525305

KK-mn020

KK-mn021

KK-mn026

KK-mn029

KK-mn031

KK-mn032
Diorite

Alkalic Gabbro

Alkalic Gabbro

Quartzolite

Granodiorite

Diorite

Alkalic Gabbro

Alkalic Gabbro

Subalkalic Gabbro

Granite

Granite

Diorite

Subalkalic Gabbro

Subalkalic Gabbro

Granite

Mantle Peridotite

Quartzolite

Granodiorite

Diorite

Monzodiorite

Granodiorite

Subalkalic Gabbro

Subalkalic Gabbro

Subalkalic Gabbro

Granodiorite

Granite

Granite

Granodiorite

Granodiorite

Granodiorite

Granite

Granite

Granodiorite

Alkalic Gabbro

Subalkalic Gabbro

Granite

Quartz Monzonite

Granodiorite

Granite

Quartz Monzonite

Quartz Monzonite

Trachydacite
Reference TAS name
Modal

Chemistry CIPW Mineralog

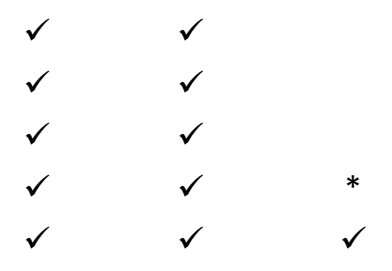

k

$\sigma$

$\left(\mathrm{W} \mathrm{m}^{-1} \mathrm{~K}^{-1}\right) \quad\left(\mathrm{W} \mathrm{m}^{-1} \mathrm{~K}^{-1}\right)$

$\begin{array}{ll}2.73 & 0.07 \\ 2.81 & 0.04 \\ 2.67 & 0.03\end{array}$

$6.77 \quad 0.33$

$3.33 \quad 0.07$

$2.89 \quad 0.04$

$2.86 \quad 0.06$

$2.58 \quad 0.03$

$2.85 \quad 0.07$

$2.90 \quad 0.05$

$3.09 \quad 0.04$

$2.91 \quad 0.07$

$2.90 \quad 0.06$

$2.96 \quad 0.05$

$\begin{array}{ll}3.18 & 0.08\end{array}$

$2.37 \quad 0.04$

$5.09 \quad 0.19$

$2.94 \quad 0.04$

$2.74 \quad 0.10$

$2.66 \quad 0.03$

$3.30 \quad 0.06$

$2.87 \quad 0.05$

$2.66 \quad 0.05$

$2.77 \quad 0.04$

$2.65 \quad 0.03$

$2.74 \quad 0.04$

$3.26 \quad 0.08$

$3.32 \quad 0.06$

$3.11 \quad 0.06$

$3.11 \quad 0.07$

$2.96 \quad 0.11$

$\begin{array}{ll}2.84 & 0.07\end{array}$

$2.73 \quad 0.06$

$2.09 \quad 0.03$

$1.89 \quad 0.03$

$\begin{array}{ll}3.05 & 0.07\end{array}$

$2.70 \quad 0.03$

$3.34 \quad 0.15$

$3.14 \quad 0.04$

$2.74 \quad 0.04$

$2.83 \quad 0.07$

$\begin{array}{ll}2.88 & 0.06\end{array}$ 
* Indicates modal estimate reported by original researcher Sample KK-mn067

$\mathrm{MO}-30114$

MO-31504

MO-32505a

$\mathrm{MO}-32603$

$\mathrm{MO}-32704$

MO-32801

MO-32902a

MO-32903a

MO-40301

MO-40801a

MO-40905

MO-41001a

MO-41006a

MO-41101

MO-41104

MO-41203

MO-41301

MO-41302

MO-41602

MO-41902

MO-41903

MO-42305

MO-42402

MO-42601

MO-42602

MO-42603

MO-42703

MO-51309

MO-51703

MO-52009

MO-92006

DCL2379398

DCL2379399

DCL2379400

DCL2379401

DCL2379402

DCL2379404

DCL2379405

DCL2379406

DCL2379407

DCL2379408
Reference

TAS name

Granite

Granite

Granite

Granite

Diorite

Diorite

Diorite

Diorite

Diorite

Gabbroic Diorite

Diorite

Diorite

Diorite

Diorite

Diorite

Diorite

Diorite

Granodiorite

Diorite

Diorite

Diorite

Diorite

Granodiorite

Diorite

Diorite

Diorite

Diorite

Diorite

Diorite

Granodiorite

Granite

Peridotgabbro

Peridotgabbro

Alkalic Gabbro

Gabbroic Diorite

Cumulate Peridotite

Gabbroic Diorite

Alkalic Gabbro

Subalkalic Gabbro

Subalkalic Gabbro

Alkalic Gabbro
Granodiorite
Modal

Chemistry CIPW Mineralog

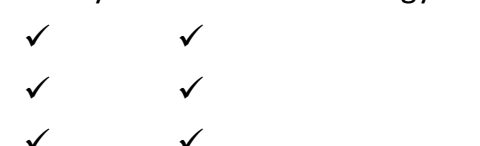

k

$\sigma$

$\left(\mathrm{W} \mathrm{m}^{-1} \mathrm{~K}^{-1}\right) \quad\left(\mathrm{W} \mathrm{m}^{-1} \mathrm{~K}^{-1}\right)$

$3.49 \quad 0.09$

$3.21 \quad 0.06$

$3.66 \quad 0.06$

$2.43 \quad 0.04$

$2.37 \quad 0.03$

$2.45 \quad 0.03$

$2.48 \quad 0.06$

$2.42 \quad 0.05$

$2.37 \quad 0.05$

$2.31 \quad 0.04$

$2.45 \quad 0.04$

$2.63 \quad 0.03$

$2.46 \quad 0.05$

$2.30 \quad 0.04$

$2.49 \quad 0.04$

$2.64 \quad 0.04$

$2.63 \quad 0.07$

$2.74 \quad 0.06$

$2.32 \quad 0.05$

$2.44 \quad 0.05$

$2.54 \quad 0.04$

$2.39 \quad 0.06$

$2.58 \quad 0.05$

$2.23 \quad 0.04$

$2.29 \quad 0.05$

$2.48 \quad 0.06$

$2.26 \quad 0.05$

$2.40 \quad 0.04$

$2.70 \quad 0.04$

$2.43 \quad 0.04$

$3.59 \quad 0.08$

$3.69 \quad 0.06$

$2.91 \quad 0.04$

$2.73 \quad 0.06$

$2.60 \quad 0.05$

$2.53 \quad 0.04$

$1.84 \quad 0.04$

$3.23 \quad 0.07$

$2.43 \quad 0.05$

$2.81 \quad 0.06$

$2.94 \quad 0.06$

$2.34 \quad 0.08$ 
* Indicates modal estimate reported by original researcher Sample DCL2379409

DCL2379411

DCL2379412

DCL2379413

DCL2379414

DCL2379415

DCL2379416

DCL2379417

DCL2379418 5

DCL2379420 5

DCL2379421 5

DCL2379422 5

DCL2379423 5

DCL2379424 5

DCL2379426 5

DCL2379427 5

DCL2379428 5

DCL2379429 5

DCL2379430 5

DCL2379431 5

DCL2379432 5

DCL2379410 5

DCL2379433 5

CC-358

CC-530

CC-069

CC-002

CC-021

CC-023

CC-026

CC-035

CC-039

CC-043

CC-068

CC-070

CC-076

CC-080

CC-081

CC-146

CC-163

CC-235

CC-301

\begin{abstract}
TAS name
\end{abstract} Alkalic Gabbro

Monzogabbro

\section{Monzogabbro}

Monzodiorite

Subalkalic Gabbro

Subalkalic Gabbro

Subalkalic Gabbro

Subalkalic Gabbro

Subalkalic Gabbro

Granodiorite

Granite

Monzodiorite

Foid Gabbro

Granodiorite

Subalkalic Gabbro

Foid Gabbro

Subalkalic Gabbro

Monzodiorite

Alkalic Gabbro

Alkalic Gabbro

Alkalic Gabbro

Subalkalic Gabbro

Subalkalic Gabbro

Subalkalic Gabbro

Subalkalic Gabbro

Subalkalic Gabbro

Subalkalic Gabbro

\section{Subalkalic Gabbro}

\section{Subalkalic Gabbro}

Gabbroic Diorite

\section{Mantle Peridotite}

Subalkalic Gabbro

\begin{abstract}
Subalkalic Gabbro
\end{abstract}
Subalkalic Gabbro

$$
\text { Subalkalic Gabbro }
$$

Subalkalic Gabbro

Subalkalic Gabbro

Subalkalic Gabbro

Subalkalic Gabbro

Subalkalic Gabbro

Subalkalic Gabbro

Subalkalic Gabbro
Modal

Chemistry CIPW Mineralog

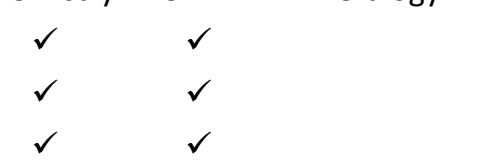

(W m ${ }^{-1}$

2.30

2.40

2.37

2.40

2.10

2.06

2.02

2.13

2.12

2.98

2.16

2.29

2.29

2.75

2.29

2.13

2.49

2.27

2.45

2.47

2.40

2.38

2.20

2.05

2.18

2.11

2.17

2.24

2.42

2.19

2.15

1.94

2.38

2.26

1.99

2.17

2.16

2.28

2.75

3.14

2.59

2.20 $\sigma$

$\left(\mathrm{W} \mathrm{m} \mathrm{m}^{-1} \mathrm{~K}^{-1}\right)$

0.05

0.03

0.02

0.03

0.03

0.03

0.02

0.02

0.03

0.09

0.02

0.03

0.03

0.03

0.06

0.06

0.03

0.02

0.02

0.04

0.03

0.02

0.03

0.06

0.04

0.03

0.07

0.04

0.05

0.04

0.07

0.12

0.09

0.04

0.03

0.11

0.03

0.11

0.11

0.08

0.06

0.09 
* Indicates modal estimate reported by original researcher Sample Reference TAS name CC-303

CC-304

CC-310

CC-312

CC-313

CC-315

CC-316

CC-318

CC-319

CC-320

CC-322

CC-323

CC-326

CC-331

CC-332

CC-334

CC-335

CC-337

CC-339

CC-342

CC-347

CC-353

CC-359

CC-374

CC-524

CC-532

CC-539

CC-540

CC-651

CC-671

CC-672

CC-675

JK-CGPJ9

JK-PGMP1

JK-CGRP7

JK-CGPJ1

JK-CGCB1

JK-HCB1

JK-MZPJ1

JK-CMPJ7

JK-GDRP8

JK-GDCB7

$\begin{array}{ll}6 & \text { Peridotgabbro } \\ 6 & \text { Peridotgabbro } \\ 6 & \text { Peridotgabbro } \\ 6 & \text { Peridotgabbro } \\ 6 & \text { Subalkalic Gabbro } \\ 6 & \text { Peridotgabbro } \\ 6 & \text { Peridotgabbro } \\ 6 & \text { Peridotgabbro } \\ 6 & \text { Subalkalic Gabbro } \\ 6 & \text { Peridotgabbro }\end{array}$

Chemis CIPW Mineralogy k

(W m-1 $\left.\mathrm{K}^{-1}\right)$

1.84

2.24

2.17

1.97

3.03

2.60

2.29

2.75

2.22

2.87

2.17

2.59

3.08

3.02

2.06

2.37

2.20

2.38

2.31

2.25

2.35

2.26

2.16

2.34

2.70

2.42

2.38

2.50

1.94

2.64

2.48

2.37

3.09

2.93

2.80

2.29

3.25

2.91

2.33

2.26

2.14

2.04 $\sigma$

$\left(\mathrm{W} \mathrm{m}^{-1} \mathrm{~K}^{-1}\right)$

0.04

0.05

0.08

0.03

0.07

0.10

0.05

0.11

0.07

0.05

0.07

0.05

0.05

0.06

0.05

0.05

0.03

0.07

0.08

0.07

0.09

0.05

0.04

0.07

0.10

0.06

0.04

0.05

0.06

0.03

0.05

0.11

0.04

0.04

0.05

0.05

0.05

0.07

0.03

0.02

0.03

0.03 
* Indicates modal estimate reported by original researcher

\section{Sample}

JK-MDPJ8

JK-MDCB5

$\mathrm{NN}-\mathrm{Pci}$

NN-Pcf

$\mathrm{NN}-\mathrm{NC4}$

$\mathrm{NN}-\mathrm{NC7}$

NN-JF2

NN-HSO

NN-PCV

NN-PP2

DB-001

DB-002

DB-003

DB-010

DB-012

DB-013

DB-032

DB-033

DB-039

DB-048

DB-050

DB-051

MD-004

MD-006

MD-008

MD-011

MD-012

MD-013

MD-014

MD-015

MD-016

MD-018

MD-019

MD-021

MD-023

$\mathrm{MH}-30$

$\mathrm{MH}-13$

PL-H64

PL-A23

PL-K33

PL-J3

DH-GA
Reference TAS name

7 Diorite

7 Alkalic Gabbro

8 Granodiorite

8 Granodiorite

8 Quartzite

8 Granite

8 Granite

8 Granite

8

Granite

8 Quartz Monzonite

9

\section{Granite}

9 Quartzite

9 Granite

9

9

\section{Granite}

Quartz Monzonite

9 Quartz Monzonite

$9 \quad$ Alkalic Gabbro

9

9

Granite

$$
\text { Granite }
$$

9 Granite

9

9

$$
\text { Granite }
$$

$$
\text { Granite }
$$$$
10 \text { Granite }
$$

10

10

Granite

$$
\text { Granite }
$$$$
10 \text { Granite }
$$

10

10

10
10

\section{Gabbroic Diorite}

Granite

Quartz Monzonite

10 Quartz Monzonite

10

10

\section{Granite}

Granite

Granite

10

10

Monzonite

Granite

Granite

11

11

Granite

Granite

Granite

12

Granite

12

Granite

13
Modal

Chemistry CIPW Mineralog

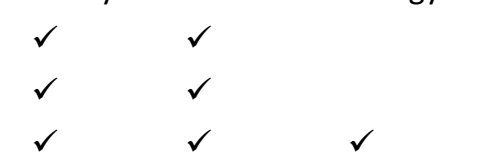

k

$\left(\mathrm{W} \mathrm{m}^{-1} \mathrm{~K}^{-1}\right) \quad\left(\mathrm{W} \mathrm{m}^{-1} \mathrm{~K}^{-1}\right)$

$2.28 \quad 0.02$

$2.22 \quad 0.02$

$2.31 \quad 0.08$

$2.44 \quad 0.02$

$4.76 \quad 0.06$

$2.62 \quad 0.04$

$2.70 \quad 0.02$

$2.65 \quad 0.04$

$2.80 \quad 0.04$

$2.29 \quad 0.02$

$2.72 \quad 0.09$

$5.24 \quad 0.05$

$2.50 \quad 0.03$

$3.43 \quad 0.12$

$2.36 \quad 0.07$

$2.51 \quad 0.11$

$2.35 \quad 0.03$

$2.53 \quad 0.04$

$2.71 \quad 0.05$

$3.28 \quad 0.05$

$3.23 \quad 0.05$

$3.14 \quad 0.05$

2.610 .03

$3.04 \quad 0.06$

$3.09 \quad 0.05$

$3.11 \quad 0.07$

$2.21 \quad 0.05$

$2.79 \quad 0.07$

$2.55 \quad 0.04$

$2.30 \quad 0.08$

$2.98 \quad 0.03$

$2.89 \quad 0.05$

$2.88 \quad 0.08$

$2.03 \quad 0.03$

$2.50 \quad 0.05$

$2.51 \quad 0.03$

$3.10 \quad 0.05$

$2.78 \quad 0.05$

$3.08 \quad 0.06$

$3.05 \quad 0.06$

$2.66 \quad 0.04$

$2.66 \quad 0.07$ 
* Indicates modal estimate reported by original researcher

\section{Sample}

DH-KG

$\mathrm{DH}-\mathrm{P}$

$\mathrm{DH}-\mathrm{BC}$

$\mathrm{DH}-\mathrm{A}$

DH-BA

$\mathrm{DH}-\mathrm{M} 2$

GJ-013

GJ-016

GJ-022

GJ-023

GJ-037

GJ-045

GJ-050

GJ-065

GJ-067

GJ-086

GJ-101

GJ-105

GJ-109

GJ-111

GJ-120

GJ-127

GJ-128

GJ-129

GJ-158

GJ-163

GJ-171

GJ-182

HF-004

HF-006

HF-007

HF-008

HF-010

HF-015

HF-017

HF-018

HF-035b

HF-036

HF-039

HF-043

HF-049

HF-050

Reference

13 Granite

13

Granite

Granite

Granite

Granite

Granite

Granite

Syenite

Quartz Monzonite

Quartz Monzonite

Quartz Monzonite

Syenite

Quartz Monzonite

Quartz Monzonite

Quartz Monzonite

Syenite

Syenite

Granite

Granite

Granite

Syenite

Quartz Monzonite

Quartz Monzonite

Quartz Monzonite

Syenite

Syenite

Syenite

Quartz Monzonite

Peridotgabbro

Alkalic Gabbro

Monzogabbro

Alkalic Gabbro

Quartz Monzonite

Granodiorite

Monzogabbro

Monzodiorite

Monzodiorite

Monzogabbro

Monzodiorite

Monzonite

Monzogabbro

Alkalic Gabbro
Modal

Chemistry CIPW Mineralogy

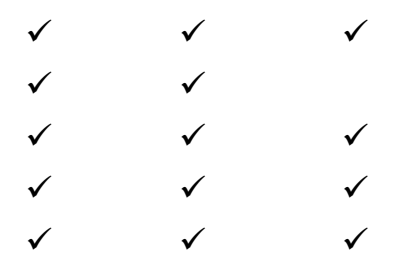

k

$\sigma$

$\left(\mathrm{W} \mathrm{m}^{-1} \mathrm{~K}^{-1}\right) \quad\left(\mathrm{W} \mathrm{m}^{-1} \mathrm{~K}^{-1}\right)$

$3.12 \quad 0.13$

$3.32 \quad 0.11$

$2.61 \quad 0.16$

$2.92 \quad 0.13$

$2.93 \quad 0.13$

$2.78 \quad 0.04$

$2.63 \quad 0.03$

$2.44 \quad 0.06$

2.33

2.54

2.39

2.32

2.35

2.27

2.21

2.65

2.19

2.48

2.61

2.59

2.50

2.42

2.40

2.55

2.21

2.03

2.41

2.37

2.43

2.48

2.39

2.71

2.40

2.60

2.09

2.26

2.63

2.48

2.13

2.24

2.18

2.50
0.05

0.03

0.03

0.02

0.03

0.02

0.03

0.03

0.02

0.04

0.04

0.04

0.04

0.02

0.04

0.04

0.03

0.03

0.03

0.03

0.04

0.06

0.02

0.03

0.04

0.03

0.08

0.05

0.05

0.03

0.02

0.02

0.03

0.02 
Sam Jennings

A new thermal conductivity model

* Indicates modal estimate reported by original researcher

Modal

$\mathrm{k}$

$\sigma$

$\begin{array}{lclccccc}\text { Sample } & \text { Reference } & \text { TAS name } & \text { Chemistry } & \text { CIPW } & \text { Mineralogy } & \left(\mathrm{W} \mathrm{m}^{-1} \mathrm{~K}^{-1}\right) & \left(\mathrm{W} \mathrm{m}^{-1} \mathrm{~K}^{-1}\right) \\ \text { HF-053 } & 15 & \text { Alkalic Gabbro } & \checkmark & \checkmark & 2.41 & 0.03 \\ \text { HF-058 } & 15 & \text { Monzodiorite } & \checkmark & \checkmark & 2.36 & 0.02 \\ \text { HF-059 } & 15 & \text { Monzodiorite } & \checkmark & \checkmark & 2.44 & 0.05 \\ \text { HF-035 } & 15 & \text { Monzodiorite } & \checkmark & \checkmark & 2.76 & 0.02\end{array}$


APPENDIX B: WHOLE ROCK GEOCHEMISTRY AND CIPW NORMATIVE MINERALOGY

\begin{tabular}{|c|c|c|c|c|c|c|c|c|c|c|c|}
\hline & Granite & Granite & Granite & Granite & Granite & Syenite & Syenite & Syenite & Syenite & Dacite & Granite \\
\hline $\mathrm{SiO} 2$ & 75.61 & 76.02 & 75.99 & 76.23 & 76.21 & 60.82 & 61.18 & 60.68 & 61.04 & 68.80 & 76.08 \\
\hline $\mathrm{Al} 2 \mathrm{O} 3$ & 10.10 & 12.85 & 12.76 & 12.49 & 12.56 & 18.37 & 18.49 & 18.45 & 18.56 & 15.67 & 12.29 \\
\hline FeOT & 3.64 & 0.60 & 0.63 & 0.88 & 0.76 & 2.92 & 2.83 & 3.19 & 2.98 & 1.50 & 1.02 \\
\hline MgO & 0.10 & 0.09 & 0.11 & 0.15 & 0.15 & 0.93 & 0.87 & 1.01 & 0.94 & 1.21 & 0.20 \\
\hline $\mathrm{CaO}$ & 0.29 & 0.36 & 0.33 & 0.28 & 0.25 & 2.27 & 2.18 & 2.27 & 2.17 & 2.77 & 0.66 \\
\hline $\mathrm{Na} 2 \mathrm{O}$ & 3.68 & 4.43 & 4.52 & 4.18 & 4.23 & 5.08 & 5.06 & 5.10 & 5.10 & 4.71 & 3.42 \\
\hline K2O & 4.66 & 4.29 & 4.33 & 4.59 & 4.55 & 5.99 & 6.12 & 5.91 & 6.04 & 2.96 & 4.85 \\
\hline $\mathrm{TiO} 2$ & 0.32 & 0.05 & 0.05 & 0.12 & 0.12 & 0.89 & 0.85 & 0.93 & 0.84 & 0.22 & 0.09 \\
\hline LOI & 0.41 & 0.43 & 0.39 & 0.40 & 0.41 & 0.31 & 0.31 & 0.31 & 0.32 & 0.92 & 0.58 \\
\hline Total & 98.88 & 99.20 & 99.19 & 99.37 & 99.32 & 97.91 & 98.18 & 98.18 & 98.27 & 98.88 & 99.26 \\
\hline \multicolumn{12}{|l|}{ CIPW norms } \\
\hline Quartz & 37.64 & 32.97 & 32.15 & 33.44 & 33.40 & 0.68 & 0.76 & 0.42 & 0.53 & 22.41 & 35.86 \\
\hline Plagioclase & 27.96 & 39.76 & 40.35 & 37.17 & 37.46 & 53.16 & 52.80 & 53.68 & 53.39 & 53.93 & 32.57 \\
\hline Orthoclase & 30.30 & 26.43 & 26.61 & 28.21 & 28.03 & 40.34 & 41.03 & 39.80 & 40.51 & 19.22 & 30.13 \\
\hline Diopside & 0.95 & 0.00 & 0.00 & 0.00 & 0.00 & 1.00 & 0.80 & 0.75 & 0.63 & 0.52 & 0.00 \\
\hline Enstatite & 2.79 & 0.62 & 0.69 & 0.81 & 0.77 & 2.62 & 2.54 & 3.05 & 2.87 & 3.15 & 1.06 \\
\hline Olivine & 0.00 & 0.00 & 0.00 & 0.00 & 0.00 & 0.00 & 0.00 & 0.00 & 0.00 & 0.00 & 0.00 \\
\hline IImenite & 0.35 & 0.05 & 0.05 & 0.13 & 0.13 & 0.98 & 0.92 & 1.01 & 0.91 & 0.24 & 0.09 \\
\hline Magnetite & 0.00 & 0.15 & 0.15 & 0.22 & 0.19 & 0.74 & 0.72 & 0.81 & 0.76 & 0.38 & 0.25 \\
\hline Apatite & 0.02 & 0.02 & 0.00 & 0.02 & 0.02 & 0.47 & 0.43 & 0.47 & 0.39 & 0.16 & 0.04 \\
\hline Total & 100.00 & 100.00 & 100.00 & 100.00 & 100.00 & 100.00 & 100.00 & 100.00 & 100.00 & 100.00 & 100.00 \\
\hline \multicolumn{12}{|c|}{ Estimated Mineralogy } \\
\hline Quartz & 18.62 & 30.14 & 48.44 & 39.97 & 30.72 & - & - & - & - & 30.00 & 40.00 \\
\hline Orthoclase & - & - & - & - & - & 81.11 & 79.65 & 80.87 & 77.46 & 30.00 & 40.00 \\
\hline Plagioclase & 0.12 & - & - & - & - & 3.62 & 3.57 & 3.01 & 8.55 & 40.00 & 10.00 \\
\hline Perthite & 73.07 & 62.15 & 49.57 & 57.44 & 64.99 & - & - & - & - & - & - \\
\hline Biotite & - & 6.78 & 0.34 & 2.59 & 2.32 & 7.77 & 8.77 & 8.12 & 7.00 & 5.00 & 5.00 \\
\hline Hornblende & - & - & - & - & - & 7.50 & 8.00 & 8.00 & 6.92 & - & 5.00 \\
\hline Clinopyroxen€ & 8.19 & - & - & - & - & - & - & - & - & - & - \\
\hline Orthopyroxen & - & - & - & - & - & - & - & - & - & - & - \\
\hline Olivine & - & - & - & - & - & - & - & - & - & - & 64 \\
\hline Spinel & - & - & - & - & - & - & - & - & - & - & - \\
\hline Total & 100.00 & 99.07 & 98.36 & 100.00 & 98.03 & 100.00 & 100.00 & 100.00 & 99.94 & 105.00 & 100.00 \\
\hline
\end{tabular}




\begin{tabular}{|c|c|c|c|c|c|c|c|c|c|c|c|}
\hline & $\begin{array}{l}\text { FR-ao85 } \\
\text { Granite }\end{array}$ & $\begin{array}{r}\text { FR-a087 } \\
\text { Subalkalic } \\
\text { Gabbro } \\
\end{array}$ & $\begin{array}{c}\text { FR-ao98 } \\
\text { Grano- } \\
\text { diorite }\end{array}$ & $\begin{array}{l}\text { FR-ay186 } \\
\text { Andesite }\end{array}$ & $\begin{array}{r}\text { FR-dm01a } \\
\text { Gabbroic } \\
\text { Diorite } \\
\end{array}$ & $\begin{array}{r}\text { FR-dm01b } \\
\text { Subalkalic } \\
\text { Gabbro } \\
\end{array}$ & $\begin{array}{l}\text { FR-dm01c } \\
\text { Granodiorite }\end{array}$ & $\begin{array}{r}\text { FR-hla110 } \\
\text { Quartz } \\
\text { Monzonite }\end{array}$ & $\begin{array}{r}\text { FR-hla111 } \\
\text { Granite }\end{array}$ & $\begin{array}{r}\text { FR-hla112 } \\
\text { Granite }\end{array}$ & $\begin{array}{r}\text { FR-hn162 } \\
\text { Rhyolite }\end{array}$ \\
\hline $\mathrm{SiO} 2$ & 76.00 & 50.67 & 68.70 & 62.23 & 54.13 & 51.81 & 64.34 & 68.04 & 71.24 & 70.39 & 75.20 \\
\hline $\mathrm{Al} 2 \mathrm{O} 3$ & 12.36 & 16.67 & 15.58 & 16.35 & 15.47 & 15.97 & 15.74 & 15.96 & 14.39 & 14.72 & 10.35 \\
\hline $\mathrm{FeOT}$ & 1.03 & 8.34 & 1.54 & 5.17 & 8.51 & 9.74 & 5.03 & 2.19 & 1.92 & 1.99 & 3.77 \\
\hline $\mathrm{MgO}$ & 0.19 & 8.10 & 1.26 & 4.15 & 4.89 & 6.25 & 1.36 & 0.71 & 0.61 & 0.67 & 0.06 \\
\hline $\mathrm{CaO}$ & 0.68 & 10.09 & 2.98 & 2.39 & 7.26 & 8.51 & 3.82 & 2.00 & 1.52 & 1.77 & 0.36 \\
\hline $\mathrm{Na} 2 \mathrm{O}$ & 3.45 & 2.01 & 4.62 & 5.69 & 3.35 & 3.01 & 4.41 & 4.58 & 3.98 & 4.11 & 4.20 \\
\hline K2O & 4.89 & 0.61 & 2.98 & 0.80 & 1.69 & 1.03 & 2.18 & 4.75 & 4.69 & 4.70 & 4.63 \\
\hline $\mathrm{TiO} 2$ & 0.09 & 0.51 & 0.22 & 0.64 & 1.32 & 1.21 & 0.73 & 0.33 & 0.29 & 0.29 & 0.27 \\
\hline LOI & 0.62 & 1.96 & 1.12 & 1.45 & 1.48 & 0.96 & 0.63 & 0.41 & 0.30 & 0.38 & 0.25 \\
\hline Total & 99.38 & 99.27 & 99.12 & 99.12 & 98.73 & 98.96 & 98.58 & 99.14 & 99.08 & 99.17 & 99.18 \\
\hline \multicolumn{12}{|l|}{ CIPW norms } \\
\hline Quartz & 35.32 & 3.22 & 22.46 & 14.38 & 6.26 & 3.05 & 19.62 & 17.11 & 25.25 & 23.14 & 35.86 \\
\hline Plagioclase & 32.90 & 57.92 & 53.24 & 64.91 & 55.78 & 58.46 & 56.28 & 48.12 & 41.44 & 42.90 & 29.59 \\
\hline Orthoclase & 30.35 & 4.51 & 19.36 & 5.64 & 12.28 & 7.53 & 15.21 & 30.65 & 30.04 & 30.14 & 30.23 \\
\hline Diopside & 0.00 & 10.94 & 1.13 & 0.00 & 8.30 & 10.08 & 0.84 & 0.59 & 0.00 & 0.62 & 1.21 \\
\hline Enstatite & 1.04 & 20.14 & 3.01 & 12.59 & 12.49 & 16.13 & 5.42 & 2.44 & 2.33 & 2.24 & 2.79 \\
\hline Olivine & 0.00 & 0.00 & 0.00 & 0.00 & 0.00 & 0.00 & 0.00 & 0.00 & 0.00 & 0.00 & 0.00 \\
\hline IImenite & 0.09 & 0.62 & 0.24 & 0.74 & 1.57 & 1.46 & 0.81 & 0.35 & 0.31 & 0.31 & 0.30 \\
\hline Magnetite & 0.26 & 2.37 & 0.39 & 1.40 & 2.35 & 2.73 & 1.31 & 0.55 & 0.48 & 0.50 & 0.00 \\
\hline Apatite & 0.04 & 0.28 & 0.16 & 0.34 & 0.97 & 0.56 & 0.50 & 0.19 & 0.15 & 0.15 & 0.02 \\
\hline Total & 100.00 & 100.00 & 100.00 & 100.00 & 100.00 & 100.00 & 100.00 & 100.00 & 100.00 & 100.00 & 100.00 \\
\hline \multicolumn{12}{|c|}{ Estimated Mineralogy } \\
\hline Quartz & 40.00 & - & 29.32 & & - & - & 20.00 & 16.77 & 24.89 & 28.64 & \\
\hline Orthoclase & 40.00 & - & 23.75 & & - & - & 5.00 & 63.57 & 43.41 & 52.00 & \\
\hline Plagioclase & 10.00 & 35.29 & 41.70 & & 50.00 & 50.00 & 50.00 & 12.23 & 22.27 & 14.94 & \\
\hline Perthite & - & - & - & & - & - & - & - & - & - & \\
\hline Biotite & 5.00 & - & 5.23 & & - & - & 5.00 & 7.43 & 9.43 & 4.42 & \\
\hline Hornblende & 5.00 & 7.61 & - & & 5.00 & 5.00 & 20.00 & - & - & - & \\
\hline Clinopyroxen€ & - & 57.10 & - & & 30.00 & 30.00 & - & - & - & - & \\
\hline Orthopyroxen & - & - & - & & 10.00 & 10.00 & - & - & - & - & \\
\hline Olivine & - & - & - & & - & - & - & - & - & - & \\
\hline Spinel & - & - & - & & - & - & - & - & - & - & \\
\hline Total & 100.00 & 100.00 & 100.00 & & 95.00 & 95.00 & 100.00 & 100.00 & 100.00 & 100.00 & \\
\hline
\end{tabular}




\begin{tabular}{|c|c|c|c|c|c|c|c|c|c|c|c|}
\hline & FR-hwg03 & FR-hwg07 & FR-hwg09 & FR-id155 & FR-id156 & FR-id159 & FR-id163 & FR-ih66 & FR-ih73 & FR-ih74 & FR-ih76 \\
\hline & Granite & Granite & Granite & Granite & Granite & Granite & Granite & Granite & Granite & Granite & Granite \\
\hline $\mathrm{SiO} 2$ & 76.51 & 71.43 & 72.94 & 74.92 & 75.27 & 75.43 & 76.28 & 74.48 & 71.92 & 71.86 & 71.62 \\
\hline $\mathrm{Al} 2 \mathrm{O} 3$ & 12.62 & 14.00 & 14.08 & 13.50 & 13.34 & 12.95 & 12.87 & 12.40 & 14.67 & 14.66 & 14.82 \\
\hline FeOT & 0.68 & 2.08 & 1.64 & 0.92 & 0.93 & 1.12 & 0.77 & 1.97 & 1.30 & 1.37 & 1.39 \\
\hline $\mathrm{MgO}$ & 0.10 & 0.43 & 0.26 & 0.12 & 0.12 & 0.14 & 0.08 & 0.35 & 0.44 & 0.46 & 0.48 \\
\hline $\mathrm{CaO}$ & 0.73 & 1.19 & 1.05 & 0.56 & 0.57 & 0.58 & 0.40 & 0.80 & 1.58 & 1.58 & 1.58 \\
\hline $\mathrm{Na} 2 \mathrm{O}$ & 3.31 & 3.15 & 3.67 & 4.18 & 4.14 & 4.15 & 4.20 & 2.78 & 3.74 & 3.77 & 3.85 \\
\hline $\mathrm{K} 2 \mathrm{O}$ & 5.24 & 5.92 & 5.27 & 5.00 & 4.79 & 4.48 & 4.54 & 5.92 & 4.75 & 4.73 & 4.67 \\
\hline $\mathrm{TiO} 2$ & 0.04 & 0.25 & 0.17 & 0.08 & 0.09 & 0.10 & 0.05 & 0.38 & 0.25 & 0.26 & 0.27 \\
\hline LOI & 0.33 & 0.61 & 0.39 & 0.34 & 0.35 & 0.36 & 0.33 & 0.43 & 0.49 & 0.49 & 0.45 \\
\hline Total & 99.59 & 99.23 & 99.56 & 99.70 & 99.68 & 99.40 & 99.57 & 99.62 & 99.26 & 99.29 & 99.24 \\
\hline \multicolumn{12}{|l|}{ CIPW norms } \\
\hline Quartz & 35.25 & 26.76 & 28.27 & 29.68 & 31.13 & 32.34 & 33.36 & 32.97 & 27.74 & 27.53 & 27.05 \\
\hline Plagioclase & 31.71 & 32.51 & 36.56 & 38.26 & 38.03 & 38.40 & 37.84 & 27.47 & 39.72 & 40.04 & 40.78 \\
\hline Orthoclase & 32.18 & 37.62 & 32.98 & 30.87 & 29.64 & 27.82 & 27.86 & 36.85 & 30.22 & 30.02 & 29.69 \\
\hline Diopside & 0.00 & 0.00 & 0.00 & 0.00 & 0.00 & 0.00 & 0.00 & 0.00 & 0.00 & 0.00 & 0.00 \\
\hline Enstatite & 0.63 & 2.13 & 1.52 & 0.84 & 0.83 & 1.01 & 0.68 & 1.70 & 1.57 & 1.65 & 1.71 \\
\hline Olivine & 0.00 & 0.00 & 0.00 & 0.00 & 0.00 & 0.00 & 0.00 & 0.00 & 0.00 & 0.00 & 0.00 \\
\hline IImenite & 0.04 & 0.27 & 0.18 & 0.08 & 0.09 & 0.11 & 0.05 & 0.40 & 0.27 & 0.28 & 0.29 \\
\hline Magnetite & 0.17 & 0.52 & 0.41 & 0.23 & 0.23 & 0.28 & 0.19 & 0.49 & 0.33 & 0.34 & 0.35 \\
\hline Apatite & 0.02 & 0.19 & 0.08 & 0.04 & 0.04 & 0.04 & 0.02 & 0.12 & 0.15 & 0.13 & 0.13 \\
\hline Total & 100.00 & 100.00 & 100.00 & 100.00 & 100.00 & 100.00 & 100.00 & 100.00 & 100.00 & 100.00 & 100.00 \\
\hline \multicolumn{12}{|c|}{ Estimated Mineralogy } \\
\hline Quartz & 19.50 & 28.17 & 26.43 & 35.16 & 40.44 & 26.92 & 41.14 & 23.00 & 35.81 & 26.31 & 21.07 \\
\hline Orthoclase & 61.82 & 46.67 & 49.44 & - & - & - & - & 72.56 & 23.35 & 55.90 & 8.95 \\
\hline Plagioclase & 17.49 & 20.86 & 18.23 & 6.61 & 3.52 & 1.33 & 0.20 & - & 37.54 & 14.30 & 61.07 \\
\hline Perthite & - & - & - & 56.29 & 54.60 & 68.43 & 58.66 & - & - & - & - \\
\hline Biotite & 1.19 & 4.30 & 5.91 & 1.95 & 1.45 & 3.33 & - & 4.44 & 3.31 & 3.49 & 8.91 \\
\hline Hornblende & - & - & - & - & - & - & - & - & - & - & - \\
\hline Clinopyroxenє & - & - & - & - & - & - & - & - & - & - & - \\
\hline Orthopyroxen & - & - & - & - & - & - & - & - & - & - & - \\
\hline Olivine & - & - & - & - & - & - & - & - & - & - & - \\
\hline Spinel & - & - & - & - & - & - & - & - & - & - & - \\
\hline Total & 100.00 & 100.00 & 100.00 & 100.00 & 100.00 & 100.00 & 100.00 & 100.00 & 100.00 & 100.00 & 100.00 \\
\hline
\end{tabular}




\begin{tabular}{|c|c|c|c|c|c|c|c|c|c|c|c|}
\hline & FR-kg142 & FR-kg145 & FR-kg150 & FR-ku121 & FR-ku123 & FR-ku139 & FR-kw13 & $\begin{array}{r}\text { FR-kw15 } \\
\text { Alkalic } \\
\text { Gabbro }\end{array}$ & $\begin{array}{r}\text { FR-kw16 } \\
\text { Alkalic } \\
\text { Gabbro }\end{array}$ & $\begin{array}{r}\text { FR-kw18 } \\
\text { Peridotgabb } \\
\text { ro }\end{array}$ & $\begin{array}{r}\text { FR-kw19 } \\
\text { Subalkalic } \\
\text { Gabbro }\end{array}$ \\
\hline $\mathrm{SiO} 2$ & 74.34 & 74.00 & 74.01 & 75.29 & 75.18 & 74.27 & 75.53 & 45.97 & 46.06 & 43.94 & 45.52 \\
\hline $\mathrm{Al} 2 \mathrm{O} 3$ & 14.12 & 14.45 & 13.92 & 13.12 & 12.99 & 13.93 & 11.16 & 25.04 & 25.31 & 21.19 & 22.30 \\
\hline $\mathrm{FeOT}$ & 0.79 & 0.24 & 0.96 & 0.94 & 1.08 & 0.70 & 2.81 & 3.05 & 3.17 & 4.63 & 4.23 \\
\hline $\mathrm{MgO}$ & 0.15 & 0.10 & 0.24 & 0.09 & 0.09 & 0.17 & 0.06 & 8.00 & 7.48 & 13.35 & 11.40 \\
\hline $\mathrm{CaO}$ & 1.31 & 1.07 & 0.97 & 0.70 & 0.59 & 1.07 & 0.42 & 11.62 & 12.06 & 9.98 & 11.09 \\
\hline $\mathrm{Na} 2 \mathrm{O}$ & 3.34 & 3.13 & 3.40 & 3.75 & 3.74 & 3.15 & 3.92 & 2.51 & 2.32 & 1.85 & 2.08 \\
\hline K2O & 4.90 & 6.14 & 5.12 & 4.98 & 4.89 & 5.93 & 4.83 & 0.16 & 0.27 & 0.12 & 0.04 \\
\hline $\mathrm{TiO} 2$ & 0.01 & 0.01 & 0.11 & 0.06 & 0.07 & 0.06 & 0.27 & 0.08 & 0.08 & 0.06 & 0.10 \\
\hline LOI & 0.19 & 0.24 & 0.56 & 0.53 & 0.50 & 0.29 & 0.14 & 3.69 & 3.30 & 4.24 & 2.82 \\
\hline Total & 99.43 & 99.49 & 99.37 & 99.50 & 99.17 & 99.62 & 99.23 & 100.26 & 100.22 & 99.51 & 99.75 \\
\hline \multicolumn{12}{|l|}{ CIPW norms } \\
\hline Quartz & 32.74 & 29.51 & 32.29 & 32.63 & 33.32 & 30.16 & 33.98 & 0.00 & 0.00 & 0.00 & 0.00 \\
\hline Plagioclase & 35.08 & 31.76 & 34.02 & 35.58 & 35.17 & 31.97 & 31.86 & 82.96 & 82.82 & 72.34 & 75.41 \\
\hline Orthoclase & 30.77 & 38.16 & 32.17 & 30.68 & 30.28 & 36.81 & 30.70 & 1.20 & 1.83 & 1.04 & 0.27 \\
\hline Diopside & 0.00 & 0.00 & 0.00 & 0.00 & 0.00 & 0.00 & 1.38 & 0.53 & 1.10 & 0.10 & 2.31 \\
\hline Enstatite & 1.16 & 0.44 & 1.08 & 0.79 & 0.88 & 0.76 & 1.69 & 0.00 & 0.00 & 1.25 & 2.12 \\
\hline Olivine & 0.00 & 0.00 & 0.00 & 0.00 & 0.00 & 0.00 & 0.00 & 14.26 & 13.17 & 23.77 & 18.47 \\
\hline IImenite & 0.01 & 0.01 & 0.12 & 0.06 & 0.07 & 0.06 & 0.30 & 0.09 & 0.09 & 0.07 & 0.12 \\
\hline Magnetite & 0.20 & 0.06 & 0.24 & 0.24 & 0.26 & 0.18 & 0.08 & 0.84 & 0.86 & 1.31 & 1.17 \\
\hline Apatite & 0.04 & 0.06 & 0.08 & 0.02 & 0.02 & 0.06 & 0.02 & 0.12 & 0.12 & 0.11 & 0.13 \\
\hline Total & 100.00 & 100.00 & 100.00 & 100.00 & 100.00 & 100.00 & 100.00 & 100.00 & 100.00 & 100.00 & 100.00 \\
\hline \multicolumn{12}{|c|}{ Estimated Mineralogy } \\
\hline Quartz & 37.04 & 46.70 & 69.04 & 27.17 & 35.00 & 30.00 & & & & & \\
\hline Orthoclase & 11.66 & - & 20.81 & - & - & 40.00 & & & & & \\
\hline Plagioclase & 48.71 & 52.22 & 2.99 & - & - & 25.00 & & & & & \\
\hline Perthite & - & - & - & 68.39 & 63.47 & - & & & & & \\
\hline Biotite & - & - & 2.17 & - & - & - & & & & & \\
\hline Hornblende & 2.58 & 1.07 & 5.00 & 4.44 & 1.53 & - & & & & & \\
\hline Clinopyroxen€ & - & - & - & - & - & - & & & & & \\
\hline Orthopyroxen & - & - & - & - & - & - & & & & & \\
\hline Olivine & - & - & - & - & - & - & & & & & \\
\hline Spinel & - & - & - & - & - & - & & & & & \\
\hline Total & 100.00 & 99.98 & 100.00 & 100.00 & 100.00 & 95.00 & & & & & \\
\hline
\end{tabular}




\begin{tabular}{|c|c|c|c|c|c|c|c|c|c|c|c|}
\hline & $\begin{array}{r}\text { FR-kw21 } \\
\text { Granite }\end{array}$ & $\begin{array}{r}\text { FR-kw22 } \\
\text { Granite }\end{array}$ & $\begin{array}{r}\text { FR-kw23 } \\
\text { Granite }\end{array}$ & $\begin{array}{r}\text { FR-kw29 } \\
\text { Granite }\end{array}$ & $\begin{array}{r}\text { FR-kw31 } \\
\text { Granite }\end{array}$ & $\begin{array}{r}\text { FR-kw32 } \\
\text { Monzonite }\end{array}$ & $\begin{array}{r}\text { FR-kw36 } \\
\text { Granite }\end{array}$ & $\begin{array}{r}\text { FR-kw38 } \\
\text { Granite }\end{array}$ & $\begin{array}{r}\text { FR-kw40 } \\
\text { Granite }\end{array}$ & $\begin{array}{r}\text { FR-kw41 } \\
\text { Granite }\end{array}$ & $\begin{array}{r}\text { FR-kw45 } \\
\text { Granite }\end{array}$ \\
\hline $\mathrm{SiO} 2$ & 74.46 & 74.86 & 75.14 & 74.87 & 75.35 & 57.43 & 73.62 & 74.65 & 76.15 & 74.74 & 71.92 \\
\hline $\mathrm{Al} 2 \mathrm{O} 3$ & 11.44 & 11.14 & 11.07 & 12.47 & 12.32 & 14.19 & 12.97 & 12.18 & 12.74 & 13.44 & 14.66 \\
\hline FeOT & 3.01 & 3.15 & 3.06 & 1.66 & 1.51 & 7.96 & 1.84 & 2.10 & 0.80 & 0.99 & 1.31 \\
\hline $\mathrm{MgO}$ & 0.07 & 0.07 & 0.07 & 0.21 & 0.19 & 3.98 & 0.33 & 0.21 & 0.13 & 0.30 & 0.41 \\
\hline $\mathrm{CaO}$ & 0.44 & 0.44 & 0.42 & 0.52 & 0.48 & 5.48 & 0.75 & 0.52 & 0.59 & 1.06 & 1.46 \\
\hline $\mathrm{Na} 2 \mathrm{O}$ & 4.01 & 3.93 & 3.93 & 3.31 & 3.29 & 3.66 & 3.35 & 3.84 & 3.86 & 3.96 & 4.33 \\
\hline $\mathrm{K} 2 \mathrm{O}$ & 5.00 & 4.92 & 4.83 & 5.41 & 5.36 & 2.41 & 5.49 & 5.07 & 4.57 & 4.12 & 4.07 \\
\hline $\mathrm{TiO} 2$ & 0.30 & 0.31 & 0.30 & 0.22 & 0.18 & 1.80 & 0.27 & 0.24 & 0.09 & 0.16 & 0.20 \\
\hline LOI & 0.15 & 0.15 & 0.10 & 0.56 & 0.49 & 1.27 & 0.34 & 0.23 & 0.12 & 0.36 & 0.58 \\
\hline Total & 98.98 & 99.06 & 99.01 & 99.27 & 99.21 & 98.73 & 99.02 & 99.11 & 99.11 & 99.20 & 99.05 \\
\hline \multicolumn{12}{|l|}{ CIPW norms } \\
\hline Quartz & 31.77 & 33.06 & 33.75 & 33.29 & 34.21 & 10.93 & 30.73 & 31.29 & 34.70 & 33.26 & 27.20 \\
\hline Plagioclase & 32.61 & 31.52 & 31.73 & 31.04 & 30.64 & 50.67 & 32.47 & 34.16 & 35.99 & 39.25 & 44.51 \\
\hline Orthoclase & 31.92 & 31.58 & 30.80 & 33.65 & 33.30 & 16.56 & 34.31 & 31.54 & 28.23 & 25.85 & 26.02 \\
\hline Diopside & 1.40 & 1.45 & 1.38 & 0.00 & 0.00 & 6.93 & 0.00 & 1.00 & 0.00 & 0.00 & 0.00 \\
\hline Enstatite & 1.85 & 2.02 & 1.95 & 1.33 & 1.24 & 9.82 & 1.67 & 1.18 & 0.75 & 1.16 & 1.61 \\
\hline Olivine & 0.00 & 0.00 & 0.00 & 0.00 & 0.00 & 0.00 & 0.00 & 0.00 & 0.00 & 0.00 & 0.00 \\
\hline Ilmenite & 0.33 & 0.34 & 0.33 & 0.23 & 0.19 & 2.11 & 0.29 & 0.25 & 0.09 & 0.17 & 0.21 \\
\hline Magnetite & 0.09 & 0.01 & 0.04 & 0.41 & 0.38 & 2.17 & 0.46 & 0.53 & 0.20 & 0.24 & 0.33 \\
\hline Apatite & 0.04 & 0.02 & 0.02 & 0.04 & 0.04 & 0.81 & 0.06 & 0.04 & 0.04 & 0.06 & 0.12 \\
\hline Total & 100.00 & 100.00 & 100.00 & 100.00 & 100.00 & 100.00 & 100.00 & 100.00 & 100.00 & 100.00 & 100.00 \\
\hline \multicolumn{12}{|c|}{ Estimated Mineralogy } \\
\hline Quartz & 45.51 & 39.04 & 27.86 & & & & & & & & \\
\hline Orthoclase & - & - & - & & & & & & & & \\
\hline Plagioclase & 0.62 & 1.95 & - & & & & & & & & \\
\hline Perthite & 50.38 & 55.20 & 66.57 & & & & & & & & \\
\hline Biotite & - & - & - & & & & & & & & \\
\hline Hornblende & - & - & - & & & & & & & & \\
\hline Clinopyroxenє & 3.54 & 3.81 & 5.57 & & & & & & & & \\
\hline Orthopyroxen & - & - & - & & & & & & & & \\
\hline Olivine & - & - & - & & & & & & & & \\
\hline Spinel & - & - & - & & & & & & & & \\
\hline Total & 100.04 & 100.00 & 100.00 & & & & & & & & \\
\hline
\end{tabular}




\begin{tabular}{|c|c|c|c|c|c|c|c|c|c|c|c|}
\hline & $\begin{array}{l}\text { FR-kw46 } \\
\text { Granite }\end{array}$ & $\begin{array}{l}\text { FR-kw50 } \\
\text { Granite }\end{array}$ & $\begin{array}{l}\text { FR-ky124 } \\
\text { Rhyolite }\end{array}$ & $\begin{array}{l}\text { FR-ky125 } \\
\text { Rhyolite }\end{array}$ & $\begin{array}{c}\text { FR-ky126 } \\
\text { Rhyolite }\end{array}$ & $\begin{array}{r}\text { FR-ky129 } \\
\text { Quartz } \\
\text { Monzonite } \\
\end{array}$ & $\begin{array}{r}\text { FR-ky130 } \\
\text { Quartz Monzonite }\end{array}$ & $\begin{array}{l}\text { FR-md93 } \\
\text { Granite }\end{array}$ & $\begin{array}{l}\text { FR-md95 } \\
\text { Granite }\end{array}$ & $\begin{array}{r}\text { FR-mr189 } \\
\text { Syenite }\end{array}$ & $\begin{array}{r}\text { FR-mr190 } \\
\text { Syenite }\end{array}$ \\
\hline $\mathrm{SiO} 2$ & 74.93 & 71.34 & 70.93 & 71.33 & 71.63 & 64.18 & 63.57 & 69.43 & 69.69 & 59.80 & 60.01 \\
\hline $\mathrm{Al} 2 \mathrm{O} 3$ & 12.72 & 14.75 & 15.47 & 15.09 & 15.18 & 17.72 & 17.91 & 16.03 & 16.09 & 18.53 & 18.26 \\
\hline $\mathrm{FeOT}$ & 1.54 & 1.41 & 0.68 & 0.67 & 0.70 & 2.46 & 2.56 & 1.44 & 1.43 & 3.82 & 4.03 \\
\hline MgO & 0.25 & 0.47 & 0.28 & 0.27 & 0.28 & 0.96 & 1.02 & 0.83 & 0.85 & 0.89 & 0.77 \\
\hline $\mathrm{CaO}$ & 0.54 & 1.53 & 1.63 & 1.72 & 1.64 & 2.56 & 2.72 & 2.51 & 2.56 & 3.16 & 3.09 \\
\hline $\mathrm{Na} 2 \mathrm{O}$ & 3.38 & 4.37 & 5.32 & 5.22 & 5.24 & 4.96 & 4.96 & 5.02 & 5.12 & 6.76 & 6.75 \\
\hline $\mathrm{K} 2 \mathrm{O}$ & 5.51 & 4.02 & 3.53 & 3.36 & 3.31 & 4.71 & 4.56 & 2.73 & 2.75 & 3.01 & 3.10 \\
\hline $\mathrm{TiO} 2$ & 0.22 & 0.23 & 0.10 & 0.10 & 0.10 & 0.45 & 0.47 & 0.27 & 0.27 & 0.77 & 0.79 \\
\hline LOI & 0.28 & 0.62 & 1.17 & 1.26 & 1.19 & 0.39 & 0.43 & 0.63 & 0.68 & 1.18 & 0.98 \\
\hline Total & 99.42 & 98.86 & 99.16 & 99.07 & 99.32 & 98.64 & 98.48 & 99.04 & 99.59 & 98.28 & 98.16 \\
\hline \multicolumn{12}{|l|}{ CIPW norms } \\
\hline Quartz & 32.31 & 26.36 & 22.28 & 24.05 & 24.36 & 9.27 & 8.79 & 22.90 & 22.24 & 0.00 & 0.01 \\
\hline Plagioclase & 31.57 & 45.26 & 53.53 & 52.80 & 53.08 & 54.69 & 55.70 & 55.80 & 56.49 & 71.00 & 70.26 \\
\hline Orthoclase & 34.12 & 25.88 & 22.69 & 21.52 & 21.15 & 31.21 & 30.42 & 17.97 & 17.92 & 21.62 & 21.88 \\
\hline Diopside & 0.00 & 0.00 & 0.33 & 0.64 & 0.17 & 0.11 & 0.00 & 0.00 & 0.00 & 2.92 & 3.23 \\
\hline Enstatite & 1.35 & 1.77 & 0.82 & 0.64 & 0.88 & 3.21 & 3.48 & 2.48 & 2.51 & 1.49 & 2.31 \\
\hline Olivine & 0.00 & 0.00 & 0.00 & 0.00 & 0.00 & 0.00 & 0.00 & 0.00 & 0.00 & 0.73 & 0.00 \\
\hline Ilmenite & 0.23 & 0.24 & 0.11 & 0.11 & 0.11 & 0.49 & 0.52 & 0.29 & 0.29 & 0.86 & 0.88 \\
\hline Magnetite & 0.38 & 0.36 & 0.17 & 0.17 & 0.18 & 0.62 & 0.64 & 0.37 & 0.36 & 0.98 & 1.04 \\
\hline Apatite & 0.04 & 0.13 & 0.06 & 0.06 & 0.06 & 0.39 & 0.45 & 0.19 & 0.19 & 0.39 & 0.39 \\
\hline Total & 100.00 & 100.00 & 100.00 & 100.00 & 100.00 & 100.00 & 100.00 & 100.00 & 100.00 & 100.00 & 100.00 \\
\hline \multicolumn{12}{|c|}{ Estimated Mineralogy } \\
\hline Quartz & & & 15.00 & 15.00 & 15.00 & 16.51 & 25.89 & & & - & - \\
\hline Orthoclase & & & 40.00 & 40.00 & 40.00 & - & - & & & 82.37 & 89.12 \\
\hline Plagioclase & & & 40.00 & 40.00 & 40.00 & - & - & & & - & - \\
\hline Perthite & & & - & - & - & 71.11 & 66.90 & & & - & - \\
\hline Biotite & & & - & - & - & 12.38 & 7.21 & & & 5.63 & 3.00 \\
\hline Hornblende & & & - & - & - & - & - & & & 12.00 & 7.88 \\
\hline Clinopyroxene & & & - & - & - & - & - & & & - & - \\
\hline Orthopyroxene & & & - & - & - & - & - & & & - & - \\
\hline Olivine & & & - & - & - & - & - & & & - & - \\
\hline Spinel & & & - & - & - & - & - & & & - & - \\
\hline Total & & & 95.00 & 95.00 & 95.00 & 100.00 & 100.00 & & & 100.00 & 100.00 \\
\hline
\end{tabular}




\begin{tabular}{|c|c|c|c|c|c|c|c|c|c|}
\hline & $\begin{array}{r}\text { FR-mu131 } \\
\text { Basaltic } \\
\text { Trachyandesite }\end{array}$ & $\begin{array}{r}\text { FR-mu132 } \\
\text { Basaltic } \\
\text { Trachyandesite }\end{array}$ & FR-nr117 & $\begin{array}{r}\text { FR-nr119 } \\
\text { Granite }\end{array}$ & $\begin{array}{r}\text { FR-rt181 } \\
\text { Gabbroic } \\
\text { Diorite }\end{array}$ & $\begin{array}{r}\text { FR-rt183 } \\
\text { Diorite }\end{array}$ & $\begin{array}{r}\text { FR-rt185 } \\
\text { Gabbroic Diorite }\end{array}$ & $\begin{array}{r}\text { FR-su214 } \\
\text { Granodiorite }\end{array}$ & $\begin{array}{r}\text { FR-su215 } \\
\text { Granodiorite }\end{array}$ \\
\hline $\mathrm{SiO} 2$ & 52.80 & 53.36 & 73.93 & 74.33 & 56.53 & 57.19 & 54.11 & 65.08 & 65.44 \\
\hline Al2O3 & 16.48 & 16.61 & 13.35 & 13.18 & 17.92 & 17.77 & 17.53 & 15.76 & 15.65 \\
\hline FeOT & 7.64 & 7.26 & 1.40 & 1.31 & 7.54 & 7.34 & 8.23 & 4.13 & 3.97 \\
\hline MgO & 4.44 & 4.12 & 0.28 & 0.27 & 3.98 & 3.86 & 4.76 & 1.99 & 1.89 \\
\hline $\mathrm{CaO}$ & 6.20 & 5.77 & 0.97 & 0.98 & 7.17 & 7.24 & 7.39 & 4.01 & 4.07 \\
\hline $\mathrm{Na} 2 \mathrm{O}$ & 4.00 & 4.32 & 3.27 & 3.17 & 3.33 & 3.40 & 3.07 & 4.06 & 4.14 \\
\hline K2O & 2.28 & 2.31 & 5.33 & 5.30 & 0.56 & 0.52 & 0.86 & 2.18 & 2.22 \\
\hline $\mathrm{TiO} 2$ & 1.48 & 1.33 & 0.15 & 0.15 & 0.65 & 0.64 & 0.67 & 0.62 & 0.59 \\
\hline LOI & 2.55 & 2.79 & 0.36 & 0.44 & 1.48 & 1.39 & 2.62 & 1.16 & 1.13 \\
\hline Total & 98.56 & 98.45 & 99.16 & 99.25 & 99.46 & 99.65 & 99.53 & 99.23 & 99.34 \\
\hline \multicolumn{10}{|l|}{ CIPW norms } \\
\hline Quartz & 1.62 & 0.63 & 31.94 & 33.14 & 12.60 & 13.41 & 8.83 & 21.53 & 21.58 \\
\hline Plagioclase & 59.62 & 61.24 & 32.58 & 31.68 & 65.37 & 65.14 & 63.41 & 55.00 & 54.77 \\
\hline Orthoclase & 16.52 & 17.22 & 33.40 & 33.22 & 3.93 & 3.58 & 6.04 & 14.47 & 14.64 \\
\hline Diopside & 5.52 & 5.37 & 0.00 & 0.00 & 1.75 & 2.34 & 3.22 & 0.54 & 1.24 \\
\hline Enstatite & 11.85 & 10.99 & 1.42 & 1.34 & 13.22 & 12.47 & 15.13 & 6.38 & 5.75 \\
\hline Olivine & 0.00 & 0.00 & 0.00 & 0.00 & 0.00 & 0.00 & 0.00 & 0.00 & 0.00 \\
\hline IImenite & 1.77 & 1.58 & 0.16 & 0.16 & 0.76 & 0.74 & 0.80 & 0.69 & 0.66 \\
\hline Magnetite & 2.13 & 2.01 & 0.35 & 0.32 & 2.05 & 1.98 & 2.28 & 1.07 & 1.03 \\
\hline Apatite & 0.98 & 0.95 & 0.15 & 0.15 & 0.31 & 0.33 & 0.29 & 0.32 & 0.32 \\
\hline Total & 100.00 & 100.00 & 100.00 & 100.00 & 100.00 & 100.00 & 100.00 & 100.00 & 100.00 \\
\hline \multicolumn{10}{|c|}{ Estimated Mineralogy } \\
\hline Quartz & & & 29.44 & 28.41 & - & - & - & 18.81 & 25.39 \\
\hline Orthoclase & & & 2.77 & 0.92 & - & - & - & - & \\
\hline Plagioclase & & & 62.79 & 67.03 & 60.00 & 60.00 & 60.00 & 69.69 & 64.86 \\
\hline Perthite & & & & - & - & - & - & - & - \\
\hline Biotite & & & 5.00 & 3.64 & - & - & - & 5.50 & 5.00 \\
\hline Hornblende & & & & - & 10.00 & 10.00 & 10.00 & 6.00 & 4.76 \\
\hline Clinopyroxene & & & - & - & 30.00 & 30.00 & 30.00 & - & - \\
\hline Orthopyroxene & & & - & - & - & - & - & - & - \\
\hline Olivine & & & - & - & - & - & - & - & - \\
\hline Spinel & & & - & - & - & - & - & - & - \\
\hline Total & & & 100.00 & 100.00 & 100.00 & 100.00 & 100.00 & 100.00 & 100.00 \\
\hline
\end{tabular}




\begin{tabular}{|c|c|c|c|c|}
\hline & $\begin{array}{r}\text { FR-wb61 } \\
\text { Granite }\end{array}$ & $\begin{array}{r}\text { FR-wb62 } \\
\text { Granite }\end{array}$ & $\begin{array}{r}\text { FR-wb63 } \\
\text { Granite }\end{array}$ & $\begin{array}{r}\text { FR-wb65 } \\
\text { Granite }\end{array}$ \\
\hline $\mathrm{SiO2}$ & 71.55 & 71.47 & 71.58 & 72.65 \\
\hline $\mathrm{Al} 2 \mathrm{O} 3$ & 13.04 & 13.17 & 13.14 & 12.98 \\
\hline FeOT & 3.37 & 3.46 & 3.13 & 2.76 \\
\hline $\mathrm{MgO}$ & 0.12 & 0.13 & 0.13 & 0.12 \\
\hline $\mathrm{CaO}$ & 1.00 & 1.03 & 0.93 & 0.84 \\
\hline $\mathrm{Na} 2 \mathrm{O}$ & 3.71 & 3.73 & 3.69 & 3.69 \\
\hline $\mathrm{K} 2 \mathrm{O}$ & 5.64 & 5.65 & 5.66 & 5.65 \\
\hline $\mathrm{TiO} 2$ & 0.31 & 0.31 & 0.27 & 0.25 \\
\hline LOI & 0.37 & 0.35 & 0.55 & 0.37 \\
\hline Total & 99.25 & 99.45 & 99.20 & 99.42 \\
\hline \multicolumn{5}{|l|}{ CIPW norms } \\
\hline Quartz & 25.63 & 25.24 & 25.81 & 27.05 \\
\hline Plagioclase & 34.45 & 34.75 & 34.61 & 33.97 \\
\hline Orthoclase & 35.44 & 35.46 & 35.54 & 35.32 \\
\hline Diopside & 1.69 & 1.62 & 1.28 & 1.29 \\
\hline Enstatite & 1.53 & 1.65 & 1.62 & 1.34 \\
\hline Olivine & 0.00 & 0.00 & 0.00 & 0.00 \\
\hline Ilmenite & 0.33 & 0.33 & 0.29 & 0.27 \\
\hline Magnetite & 0.84 & 0.87 & 0.79 & 0.69 \\
\hline Apatite & 0.08 & 0.08 & 0.06 & 0.06 \\
\hline Total & 100.00 & 100.00 & 100.00 & 100.00 \\
\hline \multicolumn{5}{|c|}{ Estimated Mineralogy } \\
\hline Quartz & 15.58 & 21.95 & 21.90 & 22.32 \\
\hline Orthoclase & - & - & - & - \\
\hline Plagioclase & - & - & - & - \\
\hline Perthite & 68.66 & 70.02 & 64.33 & 62.42 \\
\hline Biotite & 15.76 & 8.03 & 13.77 & 15.26 \\
\hline Hornblende & - & - & - & - \\
\hline Clinopyroxen & - & - & - & - \\
\hline Orthopyroxen & - & - & - & - \\
\hline Olivine & - & - & - & - \\
\hline Spinel & - & - & - & - \\
\hline Total & 100.00 & 100.00 & 100.00 & 100.00 \\
\hline
\end{tabular}




\begin{tabular}{|c|c|c|c|c|c|c|c|c|c|c|}
\hline & $\begin{array}{l}\text { JP-D525001 } \\
\text { Peridotgabbro }\end{array}$ & $\begin{array}{r}\text { JP-D525006 } \\
\text { Subalkalic } \\
\text { Gabbro }\end{array}$ & $\begin{array}{r}\text { JP-D525007 } \\
\text { Subalkalic } \\
\text { Gabbro }\end{array}$ & $\begin{array}{r}\text { JP-D525011 } \\
\text { Granite }\end{array}$ & $\begin{array}{r}\text { JP-D525012 } \\
\text { Diorite }\end{array}$ & $\begin{array}{r}\text { JP-D525014 } \\
\text { Alkalic } \\
\text { Gabbro } \\
\end{array}$ & $\begin{array}{r}\text { JP-D525015 } \\
\text { Alkalic } \\
\text { Gabbro }\end{array}$ & $\begin{array}{l}\text { JP-D525016 } \\
\text { Quartzolite }\end{array}$ & $\begin{array}{l}\text { JP-D525017 } \\
\text { Granodiorite }\end{array}$ & $\begin{array}{r}\text { JP-D525018 } \\
\text { Diorite }\end{array}$ \\
\hline $\mathrm{SiO} 2$ & 44.84 & 49.93 & 47.82 & 71.44 & 62.38 & 48.44 & 45.84 & 99.45 & 69.34 & 62.39 \\
\hline $\mathrm{Al} 2 \mathrm{O} 3$ & 16.22 & 19.89 & 15.54 & 14.76 & 17.68 & 15.97 & 16.89 & 0.25 & 16.02 & 16.05 \\
\hline $\mathrm{FeOT}$ & 11.25 & 6.65 & 9.18 & 1.94 & 3.74 & 8.40 & 8.04 & 0.07 & 2.11 & 4.78 \\
\hline $\mathrm{MgO}$ & 8.94 & 6.76 & 10.30 & 0.53 & 2.01 & 9.12 & 10.40 & 0.02 & 0.82 & 2.72 \\
\hline $\mathrm{CaO}$ & 11.66 & 10.41 & 10.16 & 1.85 & 5.72 & 10.39 & 11.77 & 0.02 & 3.64 & 5.50 \\
\hline $\mathrm{Na} 2 \mathrm{O}$ & 0.99 & 2.35 & 1.03 & 3.90 & 4.10 & 1.37 & 1.13 & 0.09 & 3.86 & 3.62 \\
\hline $\mathrm{K} 2 \mathrm{O}$ & 1.25 & 0.98 & 1.59 & 4.14 & 1.75 & 2.15 & 1.95 & 0.05 & 2.39 & 1.44 \\
\hline $\mathrm{TiO} 2$ & 0.60 & 0.25 & 0.44 & 0.34 & 0.30 & 0.39 & 0.29 & 0.01 & 0.22 & 0.64 \\
\hline LOI & 2.58 & 1.63 & 2.27 & 0.46 & 1.42 & 2.26 & 2.46 & 0.04 & 0.81 & 1.63 \\
\hline Total & 98.33 & 98.85 & 98.33 & 99.36 & 99.10 & 98.49 & 98.77 & 100.01 & 99.21 & 98.77 \\
\hline \multicolumn{11}{|l|}{ CIPW norms } \\
\hline Quartz & 0.00 & 0.07 & 0.00 & 28.49 & 16.97 & 0.00 & 0.00 & 98.71 & 29.39 & 20.93 \\
\hline Plagioclase & 51.46 & 66.37 & 46.95 & 42.44 & 62.21 & 48.04 & 50.04 & 0.87 & 51.42 & 57.32 \\
\hline Orthoclase & 9.15 & 6.75 & 11.52 & 25.94 & 11.38 & 15.29 & 13.89 & 0.31 & 15.16 & 9.52 \\
\hline Diopside & 16.61 & 7.45 & 12.28 & 0.00 & 2.25 & 14.85 & 17.17 & 0.00 & 0.00 & 1.91 \\
\hline Enstatite & 8.89 & 17.19 & 24.76 & 2.14 & 5.78 & 12.94 & 0.00 & 0.09 & 3.05 & 7.98 \\
\hline Olivine & 9.74 & 0.00 & 1.18 & 0.00 & 0.00 & 5.84 & 16.17 & 0.00 & 0.00 & 0.00 \\
\hline IImenite & 0.76 & 0.30 & 0.54 & 0.36 & 0.34 & 0.48 & 0.36 & 0.01 & 0.24 & 0.73 \\
\hline Magnetite & 3.31 & 1.85 & 2.68 & 0.48 & 0.97 & 2.40 & 2.31 & 0.01 & 0.53 & 1.26 \\
\hline Apatite & 0.07 & 0.02 & 0.09 & 0.15 & 0.10 & 0.15 & 0.06 & 0.00 & 0.20 & 0.36 \\
\hline Total & 100.00 & 100.00 & 100.00 & 100.00 & 100.00 & 100.00 & 100.00 & 100.00 & 100.00 & 100.00 \\
\hline \multicolumn{11}{|c|}{ Estimated Mineralogy } \\
\hline Quartz & & & & & & & & 100.00 & & \\
\hline Orthoclase & & & & & & & & - & & \\
\hline Plagioclase & & & & & & & & - & & \\
\hline Perthite & & & & & & & & - & & \\
\hline Biotite & & & & & & & & - & & \\
\hline Hornblende & & & & & & & & - & & \\
\hline Clinopyroxene & & & & & & & & - & & \\
\hline Orthopyroxene & & & & & & & & - & & \\
\hline Olivine & & & & & & & & - & & \\
\hline Spinel & & & & & & & & - & & \\
\hline Total & & & & & & & & 100.00 & & 72 \\
\hline
\end{tabular}


JP-D525028 JP-D525036 JP-D525038 JP-D525041 JP-D525042 JP-D525045 JP-D525048

JP-D525049

JP-D525051 JP-D525057

\begin{tabular}{|c|c|c|c|c|c|c|c|c|c|c|}
\hline & Alkalic Gabbro & $\begin{array}{l}\text { Alkalic } \\
\text { Gabbro }\end{array}$ & $\begin{array}{r}\text { Subalkalic } \\
\text { Gabbro } \\
\end{array}$ & Granite & Granite & Diorite & $\begin{array}{r}\text { Subalkalic } \\
\text { Gabbro } \\
\end{array}$ & $\begin{array}{r}\text { Subalkalic } \\
\text { Gabbro } \\
\end{array}$ & Granite & $\begin{array}{r}\text { Mantle } \\
\text { Peridotite }\end{array}$ \\
\hline $\mathrm{SiO} 2$ & 48.85 & 49.52 & 49.16 & 76.30 & 72.46 & 61.42 & 48.38 & 48.50 & 70.91 & 38.41 \\
\hline $\mathrm{Al} 2 \mathrm{O} 3$ & 19.75 & 17.44 & 12.94 & 13.61 & 15.10 & 17.41 & 12.54 & 13.71 & 15.55 & 3.14 \\
\hline FeOT & 6.54 & 8.82 & 13.68 & 0.18 & 0.85 & 4.60 & 15.03 & 12.06 & 1.69 & 10.89 \\
\hline $\mathrm{MgO}$ & 6.79 & 6.32 & 6.24 & 0.09 & 0.44 & 2.71 & 4.77 & 6.81 & 0.62 & 34.90 \\
\hline $\mathrm{CaO}$ & 9.43 & 9.20 & 9.46 & 0.15 & 2.32 & 5.85 & 8.99 & 11.30 & 3.07 & 0.07 \\
\hline $\mathrm{Na} 2 \mathrm{O}$ & 2.77 & 3.04 & 2.12 & 5.07 & 4.91 & 4.00 & 2.09 & 2.32 & 3.71 & 0.02 \\
\hline K2O & 1.96 & 1.92 & 0.92 & 4.11 & 1.98 & 1.25 & 1.01 & 0.48 & 2.77 & 0.00 \\
\hline TiO2 & 0.57 & 0.72 & 1.74 & 0.03 & 0.08 & 0.46 & 3.33 & 1.35 & 0.19 & 0.21 \\
\hline LOI & 2.09 & 1.68 & 1.45 & 0.26 & 1.41 & 1.42 & 1.33 & 1.42 & 0.90 & 11.00 \\
\hline Total & 98.75 & 98.66 & 97.71 & 99.80 & 99.55 & 99.12 & 97.47 & 97.94 & 99.41 & 98.64 \\
\hline \multicolumn{11}{|l|}{ CIPW norms } \\
\hline Quartz & 0.00 & 0.00 & 4.81 & 30.65 & 31.37 & 8.27 & 8.35 & 2.55 & 31.83 & 0.00 \\
\hline Plagioclase & 64.70 & 60.05 & 47.99 & 43.86 & 54.30 & 0.57 & 46.46 & 51.63 & 47.48 & 0.00 \\
\hline Orthoclase & 13.42 & 13.30 & 6.75 & 25.13 & 12.49 & 90.63 & 7.43 & 3.50 & 17.56 & 0.00 \\
\hline Diopside & 7.48 & 12.19 & 17.68 & 0.00 & 0.00 & 0.00 & 15.70 & 22.13 & 0.00 & 0.00 \\
\hline Enstatite & 0.37 & 1.22 & 16.21 & 0.29 & 1.47 & 0.35 & 12.53 & 14.71 & 2.38 & 41.33 \\
\hline Olivine & 11.32 & 9.71 & 0.00 & 0.00 & 0.00 & 0.00 & 0.00 & 0.00 & 0.00 & 54.19 \\
\hline Ilmenite & 0.68 & 0.86 & 2.20 & 0.03 & 0.09 & 0.04 & 4.22 & 1.70 & 0.20 & 0.34 \\
\hline Magnetite & 1.80 & 2.45 & 4.02 & 0.04 & 0.22 & 0.12 & 4.44 & 3.55 & 0.43 & 4.03 \\
\hline Apatite & 0.23 & 0.23 & 0.33 & 0.00 & 0.06 & 0.02 & 0.87 & 0.24 & 0.12 & 0.10 \\
\hline Total & 100.00 & 100.00 & 100.00 & 100.00 & 100.00 & 100.00 & 100.00 & 100.00 & 100.00 & 100.00 \\
\hline
\end{tabular}

Estimated Mineralogy

Quartz

Orthoclase

Plagioclase

Perthite

Biotite

Hornblende

Clinopyroxene

Orthopyroxene

Olivine

Spinel

Total 


\begin{tabular}{|c|c|c|c|c|c|c|c|c|c|c|}
\hline & $\begin{array}{l}\text { JP-D525087 } \\
\text { Granodiorite }\end{array}$ & $\begin{array}{r}\text { JP-D525088 } \\
\text { Diorite }\end{array}$ & $\begin{array}{r}\text { JP-D525090 } \\
\text { Monzodiorit } \\
\mathrm{e}\end{array}$ & $\begin{array}{r}\text { JP-D525109 } \\
\text { Granodiorit } \\
\mathrm{e}\end{array}$ & $\begin{array}{r}\text { JP-D525117 } \\
\text { Subalkalic } \\
\text { Gabbro }\end{array}$ & $\begin{array}{r}\text { JP-D525118 } \\
\text { Subalkalic } \\
\text { Gabbro }\end{array}$ & $\begin{array}{r}\text { JP-D525119 } \\
\text { Subalkalic } \\
\text { Gabbro }\end{array}$ & $\begin{array}{l}\text { JP-D525130 } \\
\text { Granodiorite }\end{array}$ & $\begin{array}{r}\text { JP-D525138 } \\
\text { Granite }\end{array}$ & $\begin{array}{r}\text { JP-D525140 } \\
\text { Granite }\end{array}$ \\
\hline $\mathrm{SiO} 2$ & 69.94 & 62.29 & 51.53 & 68.94 & 47.80 & 47.95 & 48.08 & 68.45 & 71.40 & 72.71 \\
\hline $\mathrm{Al} 2 \mathrm{O} 3$ & 15.11 & 15.69 & 18.02 & 16.55 & 14.00 & 14.14 & 14.05 & 15.65 & 14.95 & 14.24 \\
\hline FeOT & 2.73 & 5.07 & 7.26 & 1.60 & 11.61 & 10.89 & 10.80 & 2.98 & 1.52 & 1.57 \\
\hline $\mathrm{MgO}$ & 1.02 & 2.98 & 5.35 & 0.82 & 7.59 & 7.55 & 7.71 & 0.87 & 0.49 & 0.37 \\
\hline $\mathrm{CaO}$ & 2.63 & 5.02 & 7.49 & 3.65 & 12.11 & 12.39 & 12.50 & 2.58 & 1.89 & 1.40 \\
\hline $\mathrm{Na} 2 \mathrm{O}$ & 3.90 & 3.61 & 2.78 & 4.26 & 1.71 & 1.43 & 1.65 & 4.25 & 3.82 & 3.45 \\
\hline K2O & 2.44 & 2.30 & 2.90 & 2.02 & 0.36 & 0.61 & 0.52 & 3.38 & 4.47 & 5.06 \\
\hline $\mathrm{TiO} 2$ & 0.37 & 0.66 & 0.80 & 0.15 & 1.17 & 1.19 & 1.17 & 0.57 & 0.26 & 0.23 \\
\hline LOI & 1.05 & 1.19 & 2.32 & 1.35 & 1.94 & 1.73 & 1.66 & 0.60 & 0.48 & 0.38 \\
\hline Total & 99.19 & 98.81 & 98.45 & 99.34 & 98.28 & 97.88 & 98.14 & 99.33 & 99.28 & 99.41 \\
\hline \multicolumn{11}{|l|}{ CIPW norms } \\
\hline Quartz & 32.02 & 18.12 & 0.00 & 28.06 & 3.18 & 4.38 & 3.06 & 24.35 & 27.63 & 29.85 \\
\hline Plagioclase & 47.08 & 53.38 & 56.99 & 55.61 & 50.12 & 47.96 & 49.15 & 49.24 & 41.82 & 36.34 \\
\hline Orthoclase & 15.74 & 15.05 & 19.93 & 12.88 & 2.65 & 4.50 & 3.78 & 21.38 & 27.91 & 31.45 \\
\hline Diopside & 0.00 & 2.34 & 5.89 & 0.00 & 22.39 & 22.47 & 23.72 & 0.00 & 0.00 & 0.00 \\
\hline Enstatite & 3.81 & 8.52 & 13.03 & 2.77 & 16.53 & 15.73 & 15.40 & 3.37 & 1.84 & 1.63 \\
\hline Olivine & 0.00 & 0.00 & 0.92 & 0.00 & 0.00 & 0.00 & 0.00 & 0.00 & 0.00 & 0.00 \\
\hline IImenite & 0.42 & 0.75 & 0.95 & 0.16 & 1.49 & 1.50 & 1.48 & 0.63 & 0.28 & 0.24 \\
\hline Magnetite & 0.71 & 1.34 & 2.00 & 0.41 & 3.44 & 3.22 & 3.18 & 0.75 & 0.38 & 0.39 \\
\hline Apatite & 0.22 & 0.50 & 0.29 & 0.10 & 0.20 & 0.24 & 0.22 & 0.27 & 0.13 & 0.10 \\
\hline Total & 100.00 & 100.00 & 100.00 & 100.00 & 100.00 & 100.00 & 100.00 & 100.00 & 100.00 & 100.00 \\
\hline \multicolumn{11}{|c|}{ Estimated Mineralogy } \\
\hline \multicolumn{11}{|c|}{ Quartz } \\
\hline \multicolumn{11}{|l|}{ Orthoclase } \\
\hline \multicolumn{11}{|l|}{ Plagioclase } \\
\hline \multicolumn{11}{|l|}{ Perthite } \\
\hline \multicolumn{11}{|l|}{ Biotite } \\
\hline \multicolumn{11}{|l|}{ Hornblende } \\
\hline \multicolumn{11}{|l|}{ Clinopyroxene } \\
\hline \multicolumn{11}{|c|}{ Orthopyroxene } \\
\hline \multicolumn{11}{|l|}{ Olivine } \\
\hline \multicolumn{11}{|l|}{ Spinel } \\
\hline Total & & & & & & & & & & \\
\hline
\end{tabular}




\begin{tabular}{|c|c|c|c|c|c|c|c|c|c|c|}
\hline & $\begin{array}{l}\text { JP-D525144 } \\
\text { Granodiorite }\end{array}$ & $\begin{array}{r}\text { JP-D525151 } \\
\text { Granodiorit } \\
\mathrm{e} \\
\end{array}$ & $\begin{array}{r}\text { JP-D525152 } \\
\text { Granodiorit } \\
\mathrm{e} \\
\end{array}$ & $\begin{array}{r}\text { JP-D525156 } \\
\text { Granite }\end{array}$ & $\begin{array}{r}\text { JP-D525205 } \\
\text { Granite }\end{array}$ & $\begin{array}{r}\text { JP-D525207 } \\
\text { Granodiorit } \\
\mathrm{e} \\
\end{array}$ & $\begin{array}{r}\text { JP-D525210 } \\
\text { Alkalic } \\
\text { Gabbro } \\
\end{array}$ & $\begin{array}{r}\text { JP-D525212 } \\
\text { Subalkalic } \\
\text { Gabbro } \\
\end{array}$ & $\begin{array}{r}\text { JP-D525305 } \\
\text { Granite }\end{array}$ & $\begin{array}{l}\text { JP-D525064 } \\
\text { Quartzolite }\end{array}$ \\
\hline $\mathrm{SiO} 2$ & 69.03 & 66.15 & 68.05 & 69.42 & 74.54 & 66.08 & 45.67 & 47.65 & 69.79 & 94.70 \\
\hline $\mathrm{Al} 2 \mathrm{O} 3$ & 13.70 & 15.82 & 15.91 & 15.03 & 13.26 & 16.31 & 27.50 & 27.54 & 15.40 & 2.00 \\
\hline FeOT & 4.36 & 3.39 & 2.54 & 2.73 & 1.61 & 3.42 & 3.07 & 2.96 & 2.07 & 1.73 \\
\hline MgO & 1.30 & 1.48 & 1.09 & 0.76 & 0.13 & 1.48 & 3.51 & 3.25 & 0.76 & 0.13 \\
\hline $\mathrm{CaO}$ & 1.76 & 4.08 & 3.57 & 2.25 & 0.78 & 4.11 & 15.00 & 14.08 & 1.80 & 0.02 \\
\hline $\mathrm{Na} 2 \mathrm{O}$ & 3.05 & 3.58 & 3.75 & 3.87 & 4.11 & 3.85 & 1.46 & 1.89 & 4.44 & 0.03 \\
\hline $\mathrm{K} 2 \mathrm{O}$ & 4.18 & 2.94 & 3.14 & 4.06 & 4.69 & 3.02 & 1.33 & 0.82 & 3.43 & 0.66 \\
\hline TiO2 & 0.61 & 0.49 & 0.35 & 0.52 & 0.12 & 0.48 & 0.17 & 0.18 & 0.36 & 0.08 \\
\hline LOI & 0.96 & 1.17 & 0.92 & 0.36 & 0.25 & 0.45 & 1.85 & 1.05 & 1.05 & 0.41 \\
\hline Total & 98.95 & 99.10 & 99.32 & 99.00 & 99.49 & 99.20 & 99.56 & 99.42 & 99.10 & 99.75 \\
\hline \multicolumn{11}{|l|}{ CIPW norms } \\
\hline Quartz & 30.17 & 23.61 & 25.21 & 25.86 & 30.52 & 21.34 & 0.00 & 0.00 & 26.56 & 93.64 \\
\hline Plagioclase & 35.30 & 50.43 & 49.91 & 44.00 & 38.73 & 52.31 & 77.91 & 83.72 & 47.70 & 0.29 \\
\hline Orthoclase & 27.06 & 18.81 & 19.84 & 25.59 & 28.87 & 19.18 & 9.11 & 5.38 & 21.86 & 4.12 \\
\hline Diopside & 0.00 & 0.51 & 0.00 & 0.00 & 0.00 & 0.70 & 6.99 & 3.83 & 0.00 & 0.00 \\
\hline Enstatite & 5.36 & 4.92 & 3.78 & 2.99 & 1.30 & 4.78 & 0.00 & 2.76 & 2.74 & 1.40 \\
\hline Olivine & 0.00 & 0.00 & 0.00 & 0.00 & 0.00 & 0.00 & 4.90 & 3.29 & 0.00 & 0.00 \\
\hline IImenite & 0.69 & 0.54 & 0.38 & 0.57 & 0.13 & 0.52 & 0.20 & 0.20 & 0.40 & 0.09 \\
\hline Magnetite & 1.14 & 0.87 & 0.65 & 0.69 & 0.40 & 0.87 & 0.84 & 0.78 & 0.53 & 0.43 \\
\hline Apatite & 0.28 & 0.30 & 0.22 & 0.29 & 0.04 & 0.30 & 0.04 & 0.04 & 0.21 & 0.02 \\
\hline Total & 100.00 & 100.00 & 100.00 & 100.00 & 100.00 & 100.00 & 100.00 & 100.00 & 100.00 & 100.00 \\
\hline \multicolumn{11}{|c|}{ Estimated Mineralogy } \\
\hline Quartz & & & & & & & & & & 99.13 \\
\hline Orthoclase & & & & & & & & & & - \\
\hline Plagioclase & & & & & & & & & & 0.87 \\
\hline Perthite & & & & & & & & & & - \\
\hline Biotite & & & & & & & & & & - \\
\hline Hornblende & & & & & & & & & & - \\
\hline Clinopyroxene & & & & & & & & & & - \\
\hline Orthopyroxene & & & & & & & & & & - \\
\hline Olivine & & & & & & & & & & - \\
\hline Spinel & & & & & & & & & & - \\
\hline Total & & & & & & & & & & 100.00 \\
\hline
\end{tabular}




\begin{tabular}{|c|c|c|c|c|c|c|c|}
\hline & $\begin{array}{r}\text { KK-mn020 } \\
\text { Quartz } \\
\text { Monzonite }\end{array}$ & $\begin{array}{c}\text { KK-mn021 } \\
\text { Granodiorite }\end{array}$ & KK-mn026 & $\begin{array}{r}\text { KK-mn029 } \\
\text { Quartz } \\
\text { Monzonite } \\
\end{array}$ & $\begin{array}{r}\text { KK-mn031 } \\
\text { Quartz } \\
\text { Monzonite } \\
\end{array}$ & $\begin{array}{c}\text { KK-mn032 } \\
\text { Trachydacite }\end{array}$ & $\begin{array}{r}\text { KK-mn067 } \\
\text { Granite }\end{array}$ \\
\hline $\mathrm{SiO} 2$ & 64.00 & 66.00 & 76.00 & 68.00 & 68.00 & 69.00 & 75.00 \\
\hline $\mathrm{Al} 2 \mathrm{O3}$ & 18.43 & 14.20 & 13.33 & 14.19 & 14.04 & 14.76 & 11.73 \\
\hline FeOT & 0.94 & 4.93 & 0.48 & 4.60 & 2.13 & 1.93 & 2.24 \\
\hline MgO & 3.56 & 5.97 & 0.21 & 0.26 & 2.97 & 3.29 & 0.38 \\
\hline $\mathrm{CaO}$ & 0.14 & 0.03 & 0.62 & 1.85 & 0.19 & 0.23 & 0.62 \\
\hline $\mathrm{Na} 2 \mathrm{O}$ & 8.99 & 0.17 & 3.36 & 3.33 & 5.91 & 6.58 & 1.67 \\
\hline $\mathrm{K} 2 \mathrm{O}$ & 0.15 & 6.18 & 5.56 & 5.76 & 2.46 & 2.21 & 6.14 \\
\hline $\mathrm{TiO} 2$ & 0.49 & 0.47 & 0.02 & 0.44 & 0.44 & 0.41 & 0.28 \\
\hline LOI & 1.71 & 1.62 & 0.29 & 0.45 & 0.62 & 0.49 & 1.02 \\
\hline Total & 98.41 & 99.57 & 99.87 & 98.88 & 96.76 & 98.90 & 99.08 \\
\hline \multicolumn{8}{|c|}{ CIPW norms } \\
\hline Quartz & 5.97 & 34.72 & 33.37 & 21.18 & 20.07 & 17.03 & 40.40 \\
\hline Plagioclase & 84.04 & 1.57 & 31.52 & 35.60 & 54.79 & 59.65 & 17.38 \\
\hline Orthoclase & 1.05 & 44.19 & 34.20 & 37.32 & 16.37 & 14.29 & 39.16 \\
\hline Diopside & 0.00 & 0.00 & 0.00 & 1.62 & 0.00 & 0.00 & 0.00 \\
\hline Enstatite & 8.05 & 17.41 & 0.72 & 2.48 & 7.58 & 7.99 & 2.08 \\
\hline Olivine & 0.00 & 0.00 & 0.00 & 0.00 & 0.00 & 0.00 & 0.00 \\
\hline Ilmenite & 0.57 & 0.58 & 0.02 & 0.48 & 0.51 & 0.45 & 0.30 \\
\hline Magnetite & 0.25 & 1.39 & 0.12 & 1.17 & 0.57 & 0.49 & 0.58 \\
\hline Apatite & 0.08 & 0.13 & 0.04 & 0.14 & 0.12 & 0.10 & 0.10 \\
\hline Total & 100.00 & 100.00 & 100.00 & 100.00 & 100.00 & 100.00 & 100.00 \\
\hline
\end{tabular}

Estimated Mineralogy

Quartz

Orthoclase

Plagioclase

Perthite

Biotite

Hornblende

Clinopyroxene

Orthopyroxene

Olivine

Spinel

Total 
$\mathrm{MO}-30114$

MO-31504 MO-92006 MO-32505a MO-32603

MO-32704 MO-32801 MO-32902a MO-32903a MO-40301 MO-40801a

\begin{tabular}{|c|c|c|c|c|c|c|c|c|c|c|c|}
\hline & Granite & Granite & Granite & Diorite & Diorite & Diorite & Diorite & Diorite & $\begin{array}{r}\text { Gabbroic } \\
\text { Diorite }\end{array}$ & Diorite & Diorite \\
\hline $\mathrm{SiO} 2$ & 75.85 & 76.57 & 76.32 & 60.86 & 59.42 & 59.79 & 61.75 & 59.86 & 56.24 & 58.06 & 60.55 \\
\hline $\mathrm{Al} 2 \mathrm{O} 3$ & 12.06 & 11.81 & 11.64 & 17.65 & 17.95 & 18.02 & 17.55 & 17.76 & 18.38 & 17.99 & 17.79 \\
\hline $\mathrm{FeOT}$ & 1.14 & 1.57 & 1.56 & 5.11 & 5.48 & 5.24 & 4.80 & 5.60 & 6.51 & 5.94 & 5.25 \\
\hline $\mathrm{MgO}$ & 0.26 & 0.08 & 0.22 & 2.41 & 2.83 & 2.85 & 2.38 & 2.95 & 3.59 & 3.06 & 2.57 \\
\hline $\mathrm{CaO}$ & 0.33 & 0.66 & 0.44 & 5.67 & 6.11 & 6.28 & 5.60 & 6.32 & 6.96 & 6.73 & 6.04 \\
\hline $\mathrm{Na} 2 \mathrm{O}$ & 3.94 & 4.03 & 3.94 & 3.76 & 4.17 & 3.94 & 3.97 & 3.93 & 3.65 & 3.84 & 3.95 \\
\hline K2O & 5.03 & 4.42 & 4.55 & 1.87 & 1.53 & 1.34 & 1.68 & 1.28 & 1.55 & 1.30 & 1.36 \\
\hline TiO2 & 0.18 & 0.14 & 0.13 & 0.64 & 0.72 & 0.72 & 0.65 & 0.75 & 0.88 & 0.76 & 0.72 \\
\hline LOI & 0.35 & 0.49 & 0.57 & 0.62 & 1.00 & 0.51 & 0.76 & 0.66 & 0.91 & 0.80 & 0.51 \\
\hline Total & 99.14 & 99.77 & 99.37 & 98.59 & 99.21 & 98.69 & 99.14 & 99.11 & 98.67 & 98.48 & 98.74 \\
\hline \multicolumn{12}{|l|}{ CIPW norms } \\
\hline Quartz & 32.22 & 34.16 & 34.15 & 15.54 & 11.68 & 13.75 & 16.38 & 13.92 & 8.18 & 11.62 & 15.27 \\
\hline Plagioclase & 33.91 & 35.26 & 34.23 & 60.42 & 64.36 & 64.05 & 61.26 & 63.47 & 63.96 & 64.34 & 63.25 \\
\hline Orthoclase & 31.68 & 28.04 & 28.95 & 12.67 & 10.49 & 9.26 & 11.36 & 8.83 & 11.08 & 9.15 & 9.37 \\
\hline Diopside & 1.04 & 1.74 & 1.26 & 1.10 & 2.58 & 1.95 & 1.31 & 2.28 & 2.90 & 3.00 & 1.63 \\
\hline Enstatite & 0.67 & 0.27 & 0.87 & 7.85 & 8.24 & 8.41 & 7.35 & 8.71 & 10.53 & 8.93 & 7.91 \\
\hline Olivine & 0.00 & 0.00 & 0.00 & 0.00 & 0.00 & 0.00 & 0.00 & 0.00 & 0.00 & 0.00 & 0.00 \\
\hline IImenite & 0.19 & 0.15 & 0.14 & 0.72 & 0.82 & 0.82 & 0.73 & 0.85 & 1.01 & 0.87 & 0.81 \\
\hline Magnetite & 0.28 & 0.38 & 0.38 & 1.34 & 1.44 & 1.38 & 1.25 & 1.47 & 1.74 & 1.58 & 1.38 \\
\hline Apatite & 0.02 & 0.00 & 0.02 & 0.36 & 0.39 & 0.38 & 0.36 & 0.47 & 0.60 & 0.51 & 0.38 \\
\hline Total & 100.00 & 100.00 & 100.00 & 100.00 & 100.00 & 100.00 & 100.00 & 100.00 & 100.00 & 100.00 & 100.00 \\
\hline
\end{tabular}

Estimated Mineralogy

Quartz

Orthoclase

Plagioclase

Perthite

Biotite

Hornblende

Clinopyroxene

Orthopyroxene

Olivine

Spinel

Total 


\begin{tabular}{|c|c|c|c|c|c|c|c|c|c|c|}
\hline & MO-40905 & MO-41001a & MO-41006a & $\begin{array}{r}\text { MO-41101 } \\
\text { Diorite }\end{array}$ & $\begin{array}{r}\text { MO-41104 } \\
\text { Granodiorit } \\
\mathrm{e}\end{array}$ & $\begin{array}{r}\text { MO-41203 } \\
\text { Diorite }\end{array}$ & $\begin{array}{r}\text { MO-41301 } \\
\text { Granodiorit } \\
\mathrm{e}\end{array}$ & $\begin{array}{r}\text { MO-41302 } \\
\text { Diorite }\end{array}$ & $\begin{array}{r}\text { MO-41602 } \\
\text { Diorite }\end{array}$ & $\begin{array}{r}\text { MO-41902 } \\
\text { Diorite }\end{array}$ \\
\hline $\mathrm{SiO} 2$ & 60.43 & 60.96 & 60.39 & 62.05 & 65.79 & 59.93 & 68.34 & 61.06 & 61.70 & 60.34 \\
\hline $\mathrm{Al} 2 \mathrm{O} 3$ & 17.42 & 17.37 & 17.65 & 17.42 & 15.89 & 17.55 & 15.26 & 17.41 & 17.27 & 17.53 \\
\hline $\mathrm{FeOT}$ & 4.97 & 5.25 & 5.33 & 5.03 & 4.22 & 5.09 & 3.12 & 4.86 & 4.70 & 5.34 \\
\hline $\mathrm{MgO}$ & 2.49 & 2.90 & 2.61 & 2.21 & 1.80 & 2.73 & 1.56 & 2.58 & 2.48 & 2.80 \\
\hline $\mathrm{CaO}$ & 5.68 & 6.08 & 6.09 & 5.51 & 4.40 & 5.90 & 3.99 & 5.87 & 5.61 & 5.93 \\
\hline $\mathrm{Na} 2 \mathrm{O}$ & 4.08 & 3.93 & 3.80 & 4.03 & 4.30 & 4.14 & 4.21 & 3.94 & 4.11 & 4.05 \\
\hline $\mathrm{K} 2 \mathrm{O}$ & 1.78 & 1.33 & 1.52 & 1.64 & 1.69 & 1.68 & 2.01 & 1.55 & 1.52 & 1.71 \\
\hline $\mathrm{TiO} 2$ & 0.67 & 0.61 & 0.70 & 0.61 & 0.54 & 0.65 & 0.43 & 0.67 & 0.61 & 0.65 \\
\hline LOI & 0.96 & 0.62 & 0.62 & 0.87 & 0.74 & 0.87 & 0.82 & 0.62 & 1.06 & 0.91 \\
\hline Total & 98.48 & 99.05 & 98.71 & 99.37 & 99.37 & 98.54 & 99.74 & 98.56 & 99.06 & 99.26 \\
\hline \multicolumn{11}{|c|}{ CIPW norms } \\
\hline Quartz & 13.95 & 15.55 & 15.31 & 16.79 & 22.13 & 12.68 & 25.47 & 15.81 & 16.21 & 13.20 \\
\hline Plagioclase & 61.77 & 62.03 & 61.82 & 61.21 & 57.47 & 62.76 & 53.73 & 61.62 & 61.91 & 61.85 \\
\hline Orthoclase & 12.16 & 9.13 & 10.41 & 11.11 & 11.26 & 11.49 & 13.24 & 10.56 & 10.34 & 11.63 \\
\hline Diopside & 2.46 & 2.28 & 1.86 & 1.33 & 1.42 & 2.95 & 1.73 & 2.14 & 2.05 & 2.68 \\
\hline Enstatite & 7.25 & 8.47 & 8.01 & 7.18 & 5.70 & 7.69 & 4.30 & 7.48 & 7.25 & 8.08 \\
\hline Olivine & 0.00 & 0.00 & 0.00 & 0.00 & 0.00 & 0.00 & 0.00 & 0.00 & 0.00 & 0.00 \\
\hline IImenite & 0.76 & 0.69 & 0.79 & 0.69 & 0.59 & 0.74 & 0.47 & 0.76 & 0.69 & 0.74 \\
\hline Magnetite & 1.31 & 1.38 & 1.40 & 1.31 & 1.09 & 1.35 & 0.80 & 1.27 & 1.23 & 1.40 \\
\hline Apatite & 0.34 & 0.47 & 0.40 & 0.38 & 0.34 & 0.34 & 0.26 & 0.36 & 0.32 & 0.42 \\
\hline Total & 100.00 & 100.00 & 100.00 & 100.00 & 100.00 & 100.00 & 100.00 & 100.00 & 100.00 & 100.00 \\
\hline \multicolumn{11}{|c|}{ Estimated Mineralogy } \\
\hline \multicolumn{11}{|c|}{ Quartz } \\
\hline \multicolumn{11}{|l|}{ Orthoclase } \\
\hline \multicolumn{11}{|l|}{ Plagioclase } \\
\hline \multicolumn{11}{|l|}{ Perthite } \\
\hline \multicolumn{11}{|l|}{ Biotite } \\
\hline \multicolumn{11}{|c|}{ Hornblende } \\
\hline \multicolumn{11}{|c|}{ Clinopyroxene } \\
\hline \multicolumn{11}{|c|}{ Orthopyroxene } \\
\hline \multicolumn{11}{|c|}{ Olivine } \\
\hline \multicolumn{11}{|l|}{ Spinel } \\
\hline Total & & & & & & & & & & \\
\hline
\end{tabular}




\begin{tabular}{|c|c|c|c|c|c|c|c|c|c|c|}
\hline & MO-41903 & MO-42305 & MO-42402 & MO-42601 & $\mathrm{MO}-42602$ & $\mathrm{MO}-42603$ & MO-42703 & MO-51703 & MO-51309 & MO-52009 \\
\hline & Diorite & Granodiorite & Diorite & Diorite & Diorite & Diorite & Diorite & Diorite & Granodiorite & Granite \\
\hline $\mathrm{SiO} 2$ & 60.55 & 63.62 & 58.23 & 60.95 & 60.56 & 59.36 & 62.30 & 60.70 & 67.82 & 74.30 \\
\hline $\mathrm{Al} 2 \mathrm{O} 3$ & 17.16 & 17.05 & 18.20 & 17.44 & 17.61 & 17.89 & 17.38 & 17.64 & 16.02 & 12.82 \\
\hline FeOT & 5.24 & 4.24 & 5.78 & 5.04 & 4.95 & 5.64 & 4.61 & 3.55 & 5.28 & 1.93 \\
\hline $\mathrm{MgO}$ & 2.81 & 2.19 & 3.09 & 2.46 & 2.49 & 2.76 & 2.29 & 2.59 & 1.25 & 0.24 \\
\hline $\mathrm{CaO}$ & 5.97 & 5.48 & 6.73 & 5.77 & 5.87 & 6.27 & 5.47 & 5.88 & 3.76 & 1.20 \\
\hline $\mathrm{Na} 2 \mathrm{O}$ & 4.03 & 3.99 & 3.84 & 3.95 & 4.14 & 4.00 & 4.22 & 3.82 & 4.23 & 2.44 \\
\hline $\mathrm{K} 2 \mathrm{O}$ & 1.57 & 1.37 & 1.38 & 1.61 & 1.41 & 1.62 & 1.55 & 1.50 & 1.57 & 5.22 \\
\hline $\mathrm{TiO} 2$ & 0.67 & 0.60 & 0.78 & 0.68 & 0.68 & 0.76 & 0.63 & 0.73 & 0.46 & 0.26 \\
\hline LOI & 0.97 & 0.69 & 0.78 & 1.02 & 0.73 & 0.64 & 0.82 & 0.60 & 0.53 & 0.90 \\
\hline Total & 98.97 & 99.23 & 98.81 & 98.92 & 98.44 & 98.94 & 99.27 & 97.01 & 100.92 & 99.31 \\
\hline \multicolumn{11}{|l|}{ CIPW norms } \\
\hline Quartz & 14.25 & 20.13 & 11.41 & 15.62 & 14.76 & 12.07 & 16.52 & 15.84 & 27.27 & 37.70 \\
\hline Plagioclase & 61.37 & 60.62 & 64.50 & 61.55 & 63.66 & 63.07 & 62.15 & 61.81 & 55.81 & 26.55 \\
\hline Orthoclase & 10.81 & 9.28 & 9.50 & 11.01 & 9.67 & 11.16 & 10.51 & 10.35 & 10.42 & 33.16 \\
\hline Diopside & 3.12 & 1.38 & 2.90 & 1.95 & 2.11 & 2.91 & 1.75 & 1.22 & 0.00 & 0.00 \\
\hline Enstatite & 7.84 & 6.52 & 8.88 & 7.43 & 7.37 & 8.04 & 6.82 & 8.16 & 4.78 & 1.57 \\
\hline Olivine & 0.00 & 0.00 & 0.00 & 0.00 & 0.00 & 0.00 & 0.00 & 0.00 & 0.00 & 0.00 \\
\hline IImenite & 0.76 & 0.67 & 0.89 & 0.77 & 0.77 & 0.86 & 0.71 & 0.83 & 0.50 & 0.28 \\
\hline Magnetite & 1.38 & 1.10 & 1.53 & 1.33 & 1.30 & 1.48 & 1.20 & 1.39 & 0.92 & 0.48 \\
\hline Apatite & 0.47 & 0.30 & 0.39 & 0.34 & 0.36 & 0.41 & 0.34 & 0.40 & 0.30 & 0.25 \\
\hline Total & 100.00 & 100.00 & 100.00 & 100.00 & 100.00 & 100.00 & 100.00 & 100.00 & 100.00 & 100.00 \\
\hline \multicolumn{11}{|c|}{ Estimated Mineralogy } \\
\hline Quartz & & & 16.10 & & & & & & 25.00 & \\
\hline Orthoclase & & & - & & & & & & - & \\
\hline Plagioclase & & & 51.21 & & & & & & 40.00 & \\
\hline Perthite & & & - & & & & & & - & \\
\hline Biotite & & & 12.71 & & & & & & 15.00 & \\
\hline Hornblende & & & 12.80 & & & & & & 8.00 & \\
\hline Clinopyroxene & & & - & & & & & & - & \\
\hline Orthopyroxene & & & - & & & & & & - & \\
\hline Olivine & & & - & & & & & & - & \\
\hline Spinel & & & - & & & & & & - & \\
\hline Total & & & 92.82 & & & & & & 88.00 & \\
\hline
\end{tabular}




\begin{tabular}{|c|c|c|c|c|c|c|c|c|c|c|}
\hline & $\begin{array}{r}\text { DCL2379398 } \\
\text { Peridotgabbro }\end{array}$ & $\begin{array}{r}\text { DCL2379399 } \\
\text { Peridotgabbro }\end{array}$ & $\begin{array}{r}\text { DCL2379400 } \\
\text { Alkalic Gabbro }\end{array}$ & $\begin{array}{l}\text { DCL2379401 } \\
\text { Gabbroic Diorite }\end{array}$ & $\begin{array}{r}\text { DCL2379402 } \\
\text { Cumulate } \\
\text { Peridotite } \\
\end{array}$ & $\begin{array}{r}\text { DCL2379404 } \\
\text { Gabbroic Diorite }\end{array}$ & $\begin{array}{r}\text { DCL2379405 } \\
\text { Alkalic Gabbro }\end{array}$ & $\begin{array}{r}\text { DCL2379406 } \\
\text { Subalkalic } \\
\text { Gabbro } \\
\end{array}$ & $\begin{array}{r}\text { DCL2379407 } \\
\text { Subalkalic } \\
\text { Gabbro } \\
\end{array}$ & $\begin{array}{r}\text { DCL2379408 } \\
\text { Alkalic } \\
\text { Gabbro } \\
\end{array}$ \\
\hline $\mathrm{SiO} 2$ & 44.00 & 44.40 & 47.70 & 52.90 & 33.40 & 52.30 & 50.40 & 47.30 & 48.20 & 48.80 \\
\hline $\mathrm{Al} 2 \mathrm{O} 3$ & 4.82 & 5.60 & 13.70 & 14.70 & 3.70 & 9.35 & 14.40 & 8.00 & 7.75 & 15.00 \\
\hline $\mathrm{FeOT}$ & 11.70 & 11.52 & 14.31 & 9.27 & 10.35 & 9.18 & 10.35 & 8.64 & 9.09 & 12.78 \\
\hline MgO & 27.20 & 24.60 & 6.59 & 7.55 & 23.20 & 20.60 & 11.20 & 22.10 & 22.30 & 10.90 \\
\hline $\mathrm{CaO}$ & 4.92 & 5.75 & 9.63 & 9.00 & 9.20 & 3.34 & 3.70 & 5.35 & 5.30 & 3.54 \\
\hline $\mathrm{Na} 2 \mathrm{O}$ & 0.71 & 1.06 & 2.71 & 3.64 & 0.62 & 0.64 & 0.78 & 0.69 & 0.48 & 1.73 \\
\hline K2O & 0.69 & 0.21 & 0.68 & 0.66 & 0.03 & 1.24 & 3.62 & 1.50 & 1.56 & 2.55 \\
\hline TiO2 & 0.58 & 0.72 & 1.65 & 0.72 & 0.37 & 0.37 & 0.63 & 0.36 & 0.40 & 0.64 \\
\hline LOI & 4.90 & 5.50 & 1.40 & 1.17 & 17.90 & 0.81 & 2.50 & 2.94 & 3.02 & 2.05 \\
\hline Total & 99.52 & 99.36 & 98.37 & 99.61 & 98.77 & 97.83 & 97.58 & 96.88 & 98.10 & 97.99 \\
\hline \multicolumn{11}{|c|}{ CIPW norms } \\
\hline Quartz & 0.00 & 0.00 & 0.00 & 0.00 & 0.00 & 2.75 & 3.87 & 0.00 & 0.00 & 0.06 \\
\hline Plagioclase & 17.65 & 24.03 & 54.06 & 59.13 & 11.80 & 25.29 & 29.12 & 24.54 & 22.22 & 37.98 \\
\hline Orthoclase & 5.40 & 1.64 & 4.98 & 4.60 & 0.00 & 9.28 & 26.99 & 11.49 & 11.83 & 19.25 \\
\hline Diopside & 13.46 & 15.29 & 18.14 & 16.48 & 25.76 & 0.00 & 0.00 & 9.33 & 8.75 & 0.00 \\
\hline Enstatite & 20.45 & 23.13 & 13.56 & 15.75 & 0.00 & 59.17 & 35.94 & 32.03 & 38.13 & 37.68 \\
\hline Olivine & 38.44 & 31.16 & 2.61 & 0.45 & 57.30 & 0.00 & 0.00 & 19.25 & 15.42 & 0.00 \\
\hline IImenite & 0.79 & 0.98 & 2.08 & 0.87 & 0.67 & 0.48 & 0.82 & 0.48 & 0.53 & 0.83 \\
\hline Magnetite & 3.71 & 3.67 & 4.19 & 2.59 & 4.34 & 2.77 & 3.10 & 2.66 & 2.78 & 3.88 \\
\hline Apatite & 0.09 & 0.09 & 0.38 & 0.13 & 0.13 & 0.27 & 0.15 & 0.23 & 0.34 & 0.32 \\
\hline Total & 100.00 & 100.00 & 100.00 & 100.00 & 100.00 & 100.00 & 100.00 & 100.00 & 100.00 & 100.00 \\
\hline \multicolumn{11}{|c|}{ Estimated Mineralogy } \\
\hline \multicolumn{11}{|c|}{ Quartz } \\
\hline \multicolumn{11}{|l|}{ Orthoclase } \\
\hline \multicolumn{11}{|l|}{ Plagioclase } \\
\hline \multicolumn{11}{|l|}{ Perthite } \\
\hline \multicolumn{11}{|l|}{ Biotite } \\
\hline \multicolumn{11}{|l|}{ Hornblende } \\
\hline \multicolumn{11}{|c|}{ Clinopyroxene } \\
\hline \multicolumn{11}{|c|}{ Orthopyroxene } \\
\hline \multicolumn{11}{|c|}{ Olivine } \\
\hline Spinel & & & & & & & & & & \\
\hline Total & & & & & & & & & & \\
\hline
\end{tabular}




\begin{tabular}{|c|c|c|c|c|c|c|c|c|c|c|}
\hline & $\begin{array}{r}\text { DCL2379409 } \\
\text { Alkalic Gabbro }\end{array}$ & $\begin{array}{r}\text { DCL2379411 } \\
\text { Monzogabbro }\end{array}$ & $\begin{array}{r}\text { DCL2379412 } \\
\text { Monzogabbro }\end{array}$ & $\begin{array}{l}\text { DCL2379413 } \\
\text { Monzodiorite }\end{array}$ & $\begin{array}{r}\text { DCL2379414 } \\
\text { Subalkalic } \\
\text { Gabbro } \\
\end{array}$ & $\begin{array}{r}\text { DCL2379415 } \\
\text { Subalkalic Gabbro }\end{array}$ & $\begin{array}{r}\text { DCL2379416 } \\
\text { Subalkalic } \\
\text { Gabbro } \\
\end{array}$ & $\begin{array}{r}\text { DCL2379417 } \\
\text { Subalkalic } \\
\text { Gabbro } \\
\end{array}$ & $\begin{array}{r}\text { DCL2379418 } \\
\text { Subalkalic } \\
\text { Gabbro } \\
\end{array}$ & $\begin{array}{l}\text { DCL2379420 } \\
\text { Granodiorite }\end{array}$ \\
\hline $\mathrm{SiO} 2$ & 49.50 & 51.30 & 51.40 & 52.30 & 50.00 & 50.20 & 49.90 & 50.30 & 50.30 & 67.90 \\
\hline Al2O3 & 16.00 & 14.20 & 15.10 & 15.80 & 14.10 & 13.90 & 14.90 & 14.80 & 14.20 & 13.80 \\
\hline FeOT & 13.95 & 10.80 & 10.35 & 10.44 & 10.89 & 10.89 & 10.98 & 11.16 & 10.71 & 4.37 \\
\hline MgO & 5.48 & 3.34 & 3.84 & 4.36 & 7.20 & 7.05 & 6.75 & 7.00 & 7.55 & 1.69 \\
\hline $\mathrm{CaO}$ & 4.60 & 6.95 & 6.75 & 3.74 & 10.80 & 10.60 & 10.40 & 10.80 & 11.10 & 2.02 \\
\hline $\mathrm{Na} 2 \mathrm{O}$ & 2.06 & 3.20 & 3.24 & 3.54 & 1.83 & 1.82 & 1.88 & 1.92 & 1.78 & 5.90 \\
\hline K2O & 2.82 & 2.04 & 2.14 & 2.50 & 0.15 & 0.07 & 0.05 & 0.08 & 0.05 & 0.72 \\
\hline TiO2 & 0.84 & 1.73 & 1.70 & 1.72 & 1.46 & 1.58 & 1.47 & 1.52 & 1.45 & 0.67 \\
\hline LOI & 2.20 & 3.56 & 4.02 & 4.48 & 2.24 & 2.04 & 1.64 & 1.30 & 1.51 & 0.72 \\
\hline Total & 97.44 & 97.12 & 98.54 & 98.88 & 98.67 & 98.15 & 97.97 & 98.88 & 98.65 & 97.79 \\
\hline \multicolumn{11}{|c|}{ CIPW norms } \\
\hline Quartz & 3.87 & 6.09 & 4.46 & 5.75 & 7.25 & 8.66 & 7.96 & 7.12 & 7.17 & 24.92 \\
\hline Plagioclase & 46.07 & 52.92 & 54.83 & 53.76 & 52.30 & 51.97 & 55.16 & 54.43 & 52.29 & 61.59 \\
\hline Orthoclase & 20.64 & 14.66 & 15.15 & 17.88 & 1.05 & 0.49 & 0.35 & 0.56 & 0.35 & 4.71 \\
\hline Diopside & 0.00 & 10.54 & 8.36 & 0.00 & 17.08 & 16.28 & 13.79 & 15.53 & 17.45 & 0.00 \\
\hline Enstatite & 23.90 & 9.71 & 11.45 & 16.72 & 16.83 & 16.82 & 17.22 & 16.78 & 17.33 & 6.15 \\
\hline Olivine & 0.00 & 0.00 & 0.00 & 0.00 & 0.00 & 0.00 & 0.00 & 0.00 & 0.00 & 0.00 \\
\hline Ilmenite & 1.05 & 2.15 & 2.09 & 2.13 & 1.83 & 1.98 & 1.83 & 1.87 & 1.80 & 0.76 \\
\hline Magnetite & 4.10 & 3.12 & 2.96 & 3.01 & 3.17 & 3.18 & 3.18 & 3.20 & 3.10 & 1.14 \\
\hline Apatite & 0.37 & 0.81 & 0.70 & 0.75 & 0.49 & 0.62 & 0.51 & 0.51 & 0.51 & 0.72 \\
\hline Total & 100.00 & 100.00 & 100.00 & 100.00 & 100.00 & 100.00 & 100.00 & 100.00 & 100.00 & 100.00 \\
\hline \multicolumn{11}{|c|}{ Estimated Mineralogy } \\
\hline \multicolumn{11}{|c|}{ Quartz } \\
\hline \multicolumn{11}{|l|}{ Orthoclase } \\
\hline \multicolumn{11}{|l|}{ Plagioclase } \\
\hline \multicolumn{11}{|l|}{ Perthite } \\
\hline \multicolumn{11}{|l|}{ Biotite } \\
\hline \multicolumn{11}{|l|}{ Hornblende } \\
\hline \multicolumn{11}{|c|}{ Clinopyroxene } \\
\hline \multicolumn{11}{|c|}{ Orthopyroxene } \\
\hline \multicolumn{11}{|c|}{ Olivine } \\
\hline \multicolumn{11}{|l|}{ Spinel } \\
\hline Total & & & & & & & & & & \\
\hline
\end{tabular}


DCL2379421

DCL2379422

DCL2379423

DCL2379424

DCL2379426 DCL2379427

DCL2379428

DCL2379429 DCL2379430 DCL2379431

Granite

Monzodiorite Foid Gabbro Granodiorite

Subalkalic

Foid Gabbro

Subalkalic

Monzodiorite

Alkalic

Alkalic

$\mathrm{SiO} 2$

71.20

54.30

44.10

66.20

51.90

44.60

13.50

49.70

15.90

17.73

12.69

5.99

10.17

17.73
5.80

15.80

9.63

2.31

7.63

9.67
2.67

8.09

2.90

0.50

$1.62 \quad 0.56$

$1.20 \quad 2.50$

0.95

2.50

0.88

1.77

97.15

91.57

$1.72 \quad 0.00$

$\begin{array}{rr}1.72 & 0.00 \\ 57.00 & 54.27\end{array}$

\subsection{0}

61.66

11.25

$8.35-16.05$

16.05

16.78

0.00

1.44
2.84

0.62

9.30
6.28

6.28
3.19

3.19
5.25

3.63
6.87

6.87
18.24

0.00

1.09

0.92

100.00

100.00

100.00

51.50
17.30
8.76
1.70
6.70
4.02
1.44
1.12
2.29
$\mathbf{9 4 . 8 2}$

47.90 Gabbro

Total $\quad 100.00$

100.00

100.00

100.00

Estimated Mineralogy

Quartz

Orthoclase

Plagioclase

Perthite

Biotite

Hornblende

Clinopyroxene

Orthopyroxene

Olivine

Spinel

Total 


\begin{tabular}{lrrr} 
& $\begin{array}{r}\text { DCL2379432 } \\
\text { Alkalic } \\
\text { Gabbro }\end{array}$ & $\begin{array}{r}\text { DCL2379410 } \\
\text { Subalkalic } \\
\text { Gabbro }\end{array}$ & $\begin{array}{r}\text { DCL2379433 } \\
\text { Subalkalic } \\
\text { Gabbro }\end{array}$ \\
\hline SiO2 & 49.80 & 50.50 & 49.50 \\
Al2O3 & 13.20 & 13.90 & 13.00 \\
FeOT & 14.31 & 9.81 & 13.23 \\
MgO & 5.75 & 6.70 & 5.60 \\
CaO & 9.41 & 10.20 & 7.95 \\
Na2O & 3.61 & 2.22 & 2.18 \\
K2O & 0.64 & 0.05 & 0.05 \\
TiO2 & 1.70 & 1.84 & 2.26 \\
LOI & 0.60 & 3.56 & 4.12 \\
Total & 99.02 & 98.78 & 97.89 \\
CIPW norms & & & \\
Quartz & 0.00 & 8.63 & 11.83 \\
Plagioclase & 56.04 & 54.20 & 52.47 \\
Orthoclase & 4.52 & 0.35 & 0.35 \\
Diopside & 20.93 & 16.47 & 9.80 \\
Enstatite & 8.71 & 14.72 & 18.15 \\
Olivine & 3.22 & 0.00 & 0.00 \\
IImenite & 2.09 & 2.31 & 2.91 \\
Magnetite & 4.11 & 2.86 & 3.96 \\
Apatite & 0.38 & 0.46 & 0.53 \\
Total & 100.00 & 100.00 & 100.00
\end{tabular}

Estimated Mineralogy

Quartz

Orthoclase

Plagioclase

Perthite

Biotite

Hornblende

Clinopyroxene

Orthopyroxene

Olivine

Spinel

Total 


\begin{tabular}{|c|c|c|c|c|c|c|c|c|c|c|c|}
\hline & $\begin{array}{r}\text { CC-021 } \\
\text { Subalkalic } \\
\text { Gabbro }\end{array}$ & $\begin{array}{r}\text { CC-023 } \\
\text { Subalkalic } \\
\text { Gabbro }\end{array}$ & $\begin{array}{r}\text { CC-026 } \\
\text { Subalkalic } \\
\text { Gabbro } \\
\end{array}$ & $\begin{array}{r}\text { CC-035 } \\
\text { Subalkalic } \\
\text { Gabbro } \\
\end{array}$ & $\begin{array}{r}\text { CC-039 } \\
\text { Subalkalic } \\
\text { Gabbro }\end{array}$ & $\begin{array}{r}\text { CC-043 } \\
\text { Subalkalic } \\
\text { Gabbro }\end{array}$ & $\begin{array}{r}\text { CC-651 } \\
\text { Gabbroic } \\
\text { Diorite }\end{array}$ & $\begin{array}{r}\text { CC-672 } \\
\text { Mantle } \\
\text { Peridotite } \\
\end{array}$ & $\begin{array}{r}\text { CC-675 } \\
\text { Subalkalic } \\
\text { Gabbro }\end{array}$ & $\begin{array}{r}\text { CC-002 } \\
\text { Subalkalic } \\
\text { Gabbro } \\
\end{array}$ & $\begin{array}{r}\text { CC-235 } \\
\text { Subalkalic } \\
\text { Gabbro } \\
\end{array}$ \\
\hline $\mathrm{SiO} 2$ & 50.58 & 49.59 & 50.12 & 50.82 & 49.84 & 49.02 & 52.40 & 40.91 & 49.78 & 48.11 & 45.92 \\
\hline $\mathrm{Al} 2 \mathrm{O} 3$ & 16.47 & 17.62 & 16.57 & 16.29 & 18.65 & 17.09 & 15.99 & 7.05 & 18.71 & 23.12 & 12.61 \\
\hline $\mathrm{FeOT}$ & 6.14 & 5.70 & 5.10 & 5.60 & 4.65 & 5.29 & 7.90 & 11.96 & 5.62 & 3.05 & 8.23 \\
\hline $\mathrm{MgO}$ & 10.08 & 10.82 & 11.03 & 9.72 & 9.77 & 12.24 & 9.00 & 34.69 & 9.74 & 7.38 & 21.00 \\
\hline $\mathrm{CaO}$ & 13.85 & 13.85 & 14.77 & 14.72 & 14.66 & 14.05 & 11.17 & 3.62 & 13.21 & 16.22 & 10.64 \\
\hline $\mathrm{Na} 2 \mathrm{O}$ & 2.50 & 1.98 & 1.88 & 2.33 & 1.94 & 1.84 & 2.82 & 0.41 & 2.70 & 1.50 & 0.88 \\
\hline $\mathrm{K} 2 \mathrm{O}$ & 0.08 & 0.05 & 0.05 & 0.07 & 0.08 & 0.12 & 0.12 & 0.03 & 0.07 & 0.08 & 0.06 \\
\hline TiO2 & 0.34 & 0.25 & 0.26 & 0.40 & 0.26 & 0.24 & 0.46 & 0.21 & 0.23 & 0.14 & 0.22 \\
\hline LOI & 1.78 & 1.17 & 1.82 & 1.07 & 1.28 & 2.73 & 0.16 & 6.99 & 0.66 & 1.39 & 3.42 \\
\hline Total & 101.82 & 101.03 & 101.60 & 101.02 & 101.13 & 102.62 & 100.02 & 105.87 & 100.72 & 100.99 & 102.98 \\
\hline \multicolumn{12}{|l|}{ CIPW norms } \\
\hline Quartz & 0.00 & 0.00 & 0.00 & 0.00 & 0.00 & 0.00 & 0.16 & 0.00 & 0.00 & 0.00 & 0.00 \\
\hline Plagioclase & 59.94 & 61.01 & 57.70 & 58.73 & 63.28 & 58.68 & 60.16 & 24.81 & 66.52 & 73.07 & 42.91 \\
\hline Orthoclase & 0.55 & 0.34 & 0.34 & 0.48 & 0.55 & 0.83 & 0.83 & 0.23 & 0.48 & 0.53 & 0.43 \\
\hline Diopside & 25.28 & 21.34 & 26.49 & 28.27 & 21.97 & 22.84 & 17.86 & 0.40 & 19.02 & 17.09 & 16.87 \\
\hline Enstatite & 3.37 & 6.55 & 6.20 & 4.09 & 5.83 & 2.76 & 18.19 & 7.41 & 0.00 & 2.47 & 8.86 \\
\hline Olivine & 8.71 & 8.84 & 7.50 & 6.36 & 6.74 & 13.12 & 0.00 & 63.20 & 12.14 & 5.83 & 28.24 \\
\hline Ilmenite & 0.40 & 0.30 & 0.31 & 0.48 & 0.31 & 0.29 & 0.55 & 0.27 & 0.27 & 0.16 & 0.27 \\
\hline Magnetite & 1.69 & 1.58 & 1.42 & 1.55 & 1.28 & 1.46 & 2.19 & 3.63 & 1.53 & 0.82 & 2.37 \\
\hline Apatite & 0.06 & 0.04 & 0.04 & 0.04 & 0.04 & 0.02 & 0.06 & 0.05 & 0.04 & 0.02 & 0.04 \\
\hline Total & 100.00 & 100.00 & 100.00 & 100.00 & 100.00 & 100.00 & 100.00 & 100.00 & 100.00 & 100.00 & 100.00 \\
\hline
\end{tabular}

Estimated Mineralogy

Quartz

Orthoclase

Plagioclase

Perthite

Biotite

Hornblende

Clinopyroxene

Orthopyroxene

Olivine

Spinel

Total 


\begin{tabular}{|c|c|c|c|c|c|c|c|c|c|c|c|}
\hline & $\begin{array}{r}\text { CC-068 } \\
\text { Subalkalic } \\
\text { Gabbro } \\
\end{array}$ & $\begin{array}{r}\text { CC-070 } \\
\text { Subalkalic } \\
\text { Gabbro } \\
\end{array}$ & $\begin{array}{r}\text { CC-076 } \\
\text { Subalkalic } \\
\text { Gabbro } \\
\end{array}$ & $\begin{array}{r}\text { CC-080 } \\
\text { Subalkalic } \\
\text { Gabbro } \\
\end{array}$ & $\begin{array}{r}\text { CC-081 } \\
\text { Subalkalic } \\
\text { Gabbro } \\
\end{array}$ & $\begin{array}{r}\text { CC-304 } \\
\text { Subalkalic } \\
\text { Gabbro } \\
\end{array}$ & $\begin{array}{r}\text { CC-310 } \\
\text { Subalkalic } \\
\text { Gabbro } \\
\end{array}$ & $\begin{array}{r}\mathrm{CC}-312 \\
\text { Subalkalic } \\
\text { Gabbro } \\
\end{array}$ & $\begin{array}{c}\text { CC-313 } \\
\text { Peridot- } \\
\text { gabbro }\end{array}$ & $\begin{array}{r}\text { CC-315 } \\
\text { Peridot- } \\
\text { gabbro }\end{array}$ & $\begin{array}{r}\text { CC-316 } \\
\text { Peridot- } \\
\text { gabbro }\end{array}$ \\
\hline $\mathrm{SiO} 2$ & 48.92 & 49.77 & 51.20 & 49.38 & 50.15 & 47.98 & 47.57 & 45.49 & 42.60 & 43.38 & 42.93 \\
\hline $\mathrm{Al} 2 \mathrm{O} 3$ & 19.45 & 17.43 & 17.67 & 16.08 & 16.71 & 17.65 & 19.66 & 25.89 & 16.70 & 18.83 & 18.08 \\
\hline FeOT & 6.54 & 5.81 & 5.79 & 6.49 & 5.46 & 5.28 & 3.50 & 3.03 & 6.05 & 5.13 & 5.63 \\
\hline $\mathrm{MgO}$ & 9.93 & 9.82 & 8.67 & 11.78 & 9.78 & 12.54 & 11.87 & 9.39 & 23.43 & 20.14 & 22.11 \\
\hline $\mathrm{CaO}$ & 12.06 & 14.66 & 12.80 & 13.59 & 14.90 & 14.37 & 15.11 & 14.18 & 9.90 & 10.99 & 10.21 \\
\hline $\mathrm{Na} 2 \mathrm{O}$ & 2.25 & 2.14 & 3.12 & 2.07 & 2.07 & 1.56 & 1.42 & 1.10 & 0.32 & 0.52 & 0.48 \\
\hline K2O & 0.14 & 0.07 & 0.09 & 0.11 & 0.07 & 0.04 & 0.07 & 0.24 & 0.11 & 0.15 & 0.14 \\
\hline $\mathrm{TiO} 2$ & 0.23 & 0.33 & 0.34 & 0.29 & 0.38 & 0.20 & 0.13 & 0.09 & 0.05 & 0.06 & 0.04 \\
\hline LOI & 1.45 & 1.82 & 2.47 & 2.39 & 1.33 & 2.81 & 3.13 & 3.53 & 8.26 & 6.83 & 8.32 \\
\hline Total & 100.97 & 101.85 & 102.15 & 102.18 & 100.85 & 102.43 & 102.46 & 102.94 & 107.42 & 106.03 & 107.94 \\
\hline \multicolumn{12}{|l|}{ CIPW norms } \\
\hline Quartz & 0.00 & 0.00 & 0.00 & 0.00 & 0.00 & 0.00 & 0.00 & 0.00 & 0.00 & 0.00 & 0.00 \\
\hline Plagioclase & 67.00 & 60.98 & 65.77 & 57.22 & 59.02 & 59.45 & 64.00 & 78.09 & 51.74 & 58.14 & 55.84 \\
\hline Orthoclase & 0.95 & 0.48 & 0.61 & 0.76 & 0.48 & 0.28 & 0.48 & 1.59 & 0.77 & 1.04 & 0.97 \\
\hline Diopside & 12.26 & 24.66 & 21.09 & 24.10 & 27.41 & 21.85 & 19.92 & 3.68 & 3.82 & 4.27 & 2.79 \\
\hline Enstatite & 7.88 & 3.34 & 2.36 & 3.69 & 4.97 & 2.30 & 0.17 & 2.18 & 2.75 & 2.20 & 1.16 \\
\hline Olivine & 9.79 & 8.31 & 8.17 & 12.05 & 6.14 & 14.37 & 14.28 & 13.52 & 39.10 & 32.82 & 37.59 \\
\hline IImenite & 0.27 & 0.39 & 0.40 & 0.35 & 0.45 & 0.24 & 0.15 & 0.10 & 0.06 & 0.07 & 0.05 \\
\hline Magnetite & 1.79 & 1.60 & 1.58 & 1.81 & 1.51 & 1.47 & 0.96 & 0.82 & 1.72 & 1.44 & 1.58 \\
\hline Apatite & 0.06 & 0.24 & 0.02 & 0.02 & 0.02 & 0.04 & 0.04 & 0.02 & 0.04 & 0.02 & 0.02 \\
\hline Total & 100.00 & 100.00 & 100.00 & 100.00 & 100.00 & 100.00 & 100.00 & 100.00 & 100.00 & 100.00 & 100.00 \\
\hline \multicolumn{12}{|c|}{ Estimated Mineralogy } \\
\hline Quartz & & & & & & & & & - & - & - \\
\hline Orthoclase & & & & & & & & & - & - & - \\
\hline Plagioclase & & & & & & & & & 42.16 & 36.64 & 31.82 \\
\hline Perthite & & & & & & & & & - & - & - \\
\hline Biotite & & & & & & & & & - & - & - \\
\hline Hornblende & & & & & & & & & - & - & - \\
\hline Clinopyroxene & & & & & & & & & 34.37 & 37.33 & 58.12 \\
\hline Orthopyroxene & & & & & & & & & - & - & - \\
\hline Olivine & & & & & & & & & 0.45 & 4.95 & 0.08 \\
\hline Spinel & & & & & & & & & 23.02 & 21.08 & 9.98 \\
\hline Total & & & & & & & & & 100.00 & 100.00 & 100.00 \\
\hline
\end{tabular}




\begin{tabular}{|c|c|c|c|c|c|c|c|c|c|c|c|}
\hline & $\begin{array}{r}\text { CC-318 } \\
\text { Peridot- } \\
\text { gabbro }\end{array}$ & $\begin{array}{r}\text { CC-319 } \\
\text { Subalkalic } \\
\text { Gabbro } \\
\end{array}$ & $\begin{array}{l}\text { CC-320 } \\
\text { Peridot- } \\
\text { gabbro }\end{array}$ & $\begin{array}{r}\text { CC-322 } \\
\text { Peridot- } \\
\text { gabbro }\end{array}$ & $\begin{array}{r}\text { CC-323 } \\
\text { Peridot- } \\
\text { gabbro }\end{array}$ & $\begin{array}{r}\text { CC-326 } \\
\text { Subalkalic } \\
\text { Gabbro } \\
\end{array}$ & $\begin{array}{c}\text { CC-331 } \\
\text { Peridot- } \\
\text { gabbro }\end{array}$ & $\begin{array}{r}\text { CC-332 } \\
\text { Subalkalic } \\
\text { Gabbro } \\
\end{array}$ & $\begin{array}{r}\text { CC-334 } \\
\text { Subalkalic } \\
\text { Gabbro } \\
\end{array}$ & $\begin{array}{r}\text { CC-335 } \\
\text { Subalkalic } \\
\text { Gabbro } \\
\end{array}$ & $\begin{array}{r}\text { CC-337 } \\
\text { Subalkalic } \\
\text { Gabbro }\end{array}$ \\
\hline $\mathrm{SiO} 2$ & 43.54 & 45.30 & 42.76 & 43.96 & 43.65 & 46.00 & 42.14 & 45.85 & 46.48 & 48.94 & 46.82 \\
\hline $\mathrm{Al} 2 \mathrm{O} 3$ & 20.39 & 27.28 & 11.50 & 24.60 & 20.64 & 25.74 & 3.36 & 25.27 & 14.44 & 18.46 & 20.17 \\
\hline FeOT & 5.28 & 2.29 & 6.95 & 3.51 & 4.66 & 3.11 & 10.33 & 3.08 & 6.04 & 3.45 & 4.73 \\
\hline $\mathrm{MgO}$ & 19.74 & 8.59 & 30.24 & 13.27 & 18.63 & 9.36 & 40.04 & 9.17 & 18.62 & 10.22 & 12.73 \\
\hline $\mathrm{CaO}$ & 9.46 & 14.95 & 7.24 & 12.88 & 10.67 & 14.57 & 1.49 & 14.59 & 12.88 & 16.79 & 13.91 \\
\hline $\mathrm{Na} 2 \mathrm{O}$ & 1.01 & 1.51 & 0.28 & 1.20 & 0.93 & 0.93 & 0.08 & 1.03 & 0.78 & 1.46 & 1.16 \\
\hline $\mathrm{K} 2 \mathrm{O}$ & 0.17 & 0.13 & 0.02 & 0.49 & 0.08 & 0.40 & 0.01 & 0.38 & 0.14 & 0.04 & 0.23 \\
\hline $\mathrm{TiO} 2$ & 0.05 & 0.06 & 0.07 & 0.06 & 0.03 & 0.08 & 0.10 & 0.08 & 0.17 & 0.21 & 0.14 \\
\hline LOI & 6.17 & 3.86 & 10.04 & 5.90 & 6.03 & 5.03 & 11.26 & 2.88 & 4.36 & 1.80 & 2.75 \\
\hline Total & 105.81 & 103.97 & 109.10 & 105.87 & 105.32 & 105.22 & 108.81 & 102.33 & 103.91 & 101.37 & 102.64 \\
\hline \multicolumn{12}{|l|}{ CIPW norms } \\
\hline Quartz & 0.00 & 0.00 & 0.00 & 0.00 & 0.00 & 0.00 & 0.00 & 0.00 & 0.00 & 0.00 & 0.00 \\
\hline Plagioclase & 61.18 & 80.29 & 37.12 & 70.26 & 64.83 & 75.97 & 9.87 & 75.70 & 47.08 & 60.92 & 63.62 \\
\hline Orthoclase & 1.18 & 0.89 & 0.14 & 3.41 & 0.55 & 2.65 & 0.08 & 2.52 & 0.99 & 0.27 & 1.57 \\
\hline Diopside & 0.00 & 4.85 & 4.35 & 2.59 & 0.67 & 5.12 & 0.00 & 6.27 & 21.02 & 28.44 & 14.14 \\
\hline Enstatite & 2.62 & 0.00 & 6.82 & 0.00 & 0.80 & 2.81 & 22.09 & 2.06 & 5.29 & 0.78 & 3.06 \\
\hline Olivine & 33.45 & 13.26 & 49.41 & 22.68 & 31.80 & 12.51 & 64.56 & 12.47 & 23.66 & 8.37 & 16.11 \\
\hline IImenite & 0.06 & 0.07 & 0.09 & 0.07 & 0.04 & 0.09 & 0.13 & 0.09 & 0.21 & 0.25 & 0.17 \\
\hline Magnetite & 1.49 & 0.62 & 2.03 & 0.98 & 1.29 & 0.83 & 3.25 & 0.83 & 1.72 & 0.95 & 1.29 \\
\hline Apatite & 0.02 & 0.02 & 0.05 & 0.02 & 0.02 & 0.02 & 0.02 & 0.06 & 0.02 & 0.02 & 0.04 \\
\hline Total & 100.00 & 100.00 & 100.00 & 100.00 & 100.00 & 100.00 & 100.00 & 100.00 & 100.00 & 100.00 & 100.00 \\
\hline \multicolumn{12}{|c|}{ Estimated Mineralogy } \\
\hline Quartz & & & - & - & - & & & - & - & & \\
\hline Orthoclase & & & - & - & - & & & - & - & & \\
\hline Plagioclase & & & 19.67 & 52.53 & 56.11 & & & 40.00 & 8.39 & & \\
\hline Perthite & & & - & - & - & & & - & - & & \\
\hline Biotite & & & - & - & - & & & - & - & & \\
\hline Hornblende & & & - & - & - & & & - & - & & \\
\hline Clinopyroxene & & & 37.12 & - & - & & & 54.18 & 61.10 & & \\
\hline Orthopyroxene & & & - & - & - & & & - & - & & \\
\hline Olivine & & & 0.94 & 1.33 & 0.90 & & & 2.87 & 6.63 & & \\
\hline Spinel & & & 42.27 & 46.14 & 42.99 & & & 2.95 & 23.89 & & \\
\hline Total & & & 100.00 & 100.00 & 100.00 & & & 100.00 & 100.00 & & \\
\hline
\end{tabular}




\begin{tabular}{|c|c|c|c|c|c|c|c|c|c|c|c|}
\hline & $\begin{array}{r}\text { CC-339 } \\
\text { Subalkalic } \\
\text { Gabbro }\end{array}$ & $\begin{array}{r}\text { CC-342 } \\
\text { Subalkalic } \\
\text { Gabbro }\end{array}$ & $\begin{array}{r}\text { CC-347 } \\
\text { Subalkalic } \\
\text { Gabbro }\end{array}$ & $\begin{array}{r}\text { CC-353 } \\
\text { Subalkalic } \\
\text { Gabbro }\end{array}$ & $\begin{array}{r}\text { CC-359 } \\
\text { Subalkalic } \\
\text { Gabbro }\end{array}$ & $\begin{array}{r}\text { CC-374 } \\
\text { Subalkalic } \\
\text { Gabbro }\end{array}$ & $\begin{array}{r}\text { CC-532 } \\
\text { Subalkalic } \\
\text { Gabbro }\end{array}$ & $\begin{array}{r}\text { CC-539 } \\
\text { Subalkalic } \\
\text { Gabbro }\end{array}$ & $\begin{array}{r}\text { CC-540 } \\
\text { Subalkalic } \\
\text { Gabbro }\end{array}$ & $\begin{array}{l}\text { CC-163 } \\
\text { Peridot- } \\
\text { gabbro }\end{array}$ & $\begin{array}{l}\text { CC-358 } \\
\text { Peridot- } \\
\text { gabbro }\end{array}$ \\
\hline $\mathrm{SiO} 2$ & 45.30 & 48.16 & 48.19 & 48.51 & 47.24 & 48.57 & 48.56 & 48.88 & 47.39 & 43.79 & 44.49 \\
\hline $\mathrm{Al} 2 \mathrm{O} 3$ & 19.94 & 18.99 & 18.00 & 20.76 & 22.40 & 17.35 & 17.86 & 18.10 & 14.36 & 1.57 & 21.83 \\
\hline $\mathrm{FeOT}$ & 5.49 & 4.25 & 4.23 & 3.40 & 3.81 & 4.36 & 5.06 & 4.05 & 6.64 & 9.51 & 0.92 \\
\hline $\mathrm{MgO}$ & 14.92 & 11.76 & 12.03 & 9.44 & 9.64 & 12.40 & 11.85 & 11.75 & 15.87 & 43.01 & 14.46 \\
\hline $\mathrm{CaO}$ & 12.55 & 15.49 & 15.80 & 16.16 & 14.72 & 15.51 & 15.24 & 16.25 & 13.62 & 0.13 & 11.93 \\
\hline $\mathrm{Na} 2 \mathrm{O}$ & 0.99 & 1.17 & 1.39 & 1.44 & 1.40 & 1.16 & 1.23 & 1.10 & 1.12 & 0.04 & 1.23 \\
\hline $\mathrm{K} 2 \mathrm{O}$ & 0.10 & 0.03 & 0.03 & 0.03 & 0.03 & 0.06 & 0.06 & 0.03 & 0.08 & 0.01 & 0.03 \\
\hline $\mathrm{TiO} 2$ & 0.08 & 0.15 & 0.17 & 0.15 & 0.12 & 0.18 & 0.20 & 0.16 & 0.25 & 0.11 & 0.09 \\
\hline LOI & 4.11 & 1.71 & 2.17 & 1.05 & 1.55 & 1.74 & 1.89 & 1.66 & 3.51 & 11.91 & 3.43 \\
\hline Total & 103.48 & 101.71 & 102.01 & 100.94 & 100.91 & 101.33 & 101.95 & 101.98 & 102.84 & 110.08 & 98.41 \\
\hline \multicolumn{12}{|l|}{ CIPW norms } \\
\hline Quartz & 0.00 & 0.00 & 0.00 & 0.00 & 0.00 & 0.00 & 0.00 & 0.00 & 0.00 & 0.00 & 0.00 \\
\hline Plagioclase & 63.23 & 61.09 & 59.43 & 66.77 & 71.21 & 56.76 & 58.33 & 58.29 & 48.73 & 1.22 & 71.35 \\
\hline Orthoclase & 0.69 & 0.21 & 0.21 & 0.20 & 0.20 & 0.41 & 0.41 & 0.21 & 0.56 & 0.08 & 0.20 \\
\hline Diopside & 9.05 & 21.80 & 25.66 & 21.32 & 12.93 & 25.41 & 23.49 & 26.09 & 24.90 & 0.00 & 3.73 \\
\hline Enstatite & 3.98 & 4.99 & 0.22 & 2.63 & 4.08 & 6.03 & 6.52 & 5.74 & 5.61 & 32.11 & 4.05 \\
\hline Olivine & 21.40 & 10.54 & 13.09 & 7.96 & 10.32 & 9.95 & 9.57 & 8.40 & 17.95 & 63.41 & 20.27 \\
\hline IImenite & 0.10 & 0.18 & 0.20 & 0.18 & 0.14 & 0.22 & 0.24 & 0.19 & 0.31 & 0.15 & 0.10 \\
\hline Magnetite & 1.53 & 1.17 & 1.17 & 0.92 & 1.10 & 1.22 & 1.40 & 1.06 & 1.89 & 3.02 & 0.26 \\
\hline Apatite & 0.02 & 0.02 & 0.02 & 0.02 & 0.02 & 0.00 & 0.04 & 0.02 & 0.04 & 0.00 & 0.04 \\
\hline Total & 100.00 & 100.00 & 100.00 & 100.00 & 100.00 & 100.00 & 100.00 & 100.00 & 100.00 & 100.00 & 100.00 \\
\hline \multicolumn{12}{|c|}{ Estimated Mineralogy } \\
\hline Quartz & - & - & & & & - & & & & & \\
\hline Orthoclase & - & - & & & & - & & & & & \\
\hline Plagioclase & 27.53 & 28.68 & & & & 15.20 & & & & & \\
\hline Perthite & - & - & & & & - & & & & & \\
\hline Biotite & - & - & & & & - & & & & & \\
\hline Hornblende & - & - & & & & - & & & & & \\
\hline Clinopyroxen€ & 54.32 & 63.81 & & & & 60.29 & & & & & \\
\hline Orthopyroxen & - & - & & & & - & & & & & \\
\hline Olivine & 3.56 & - & & & & 7.67 & & & & & \\
\hline Spinel & 14.58 & 7.51 & & & & 16.43 & & & & & \\
\hline Total & 100.00 & 100.00 & & & & 99.59 & & & & & \\
\hline
\end{tabular}




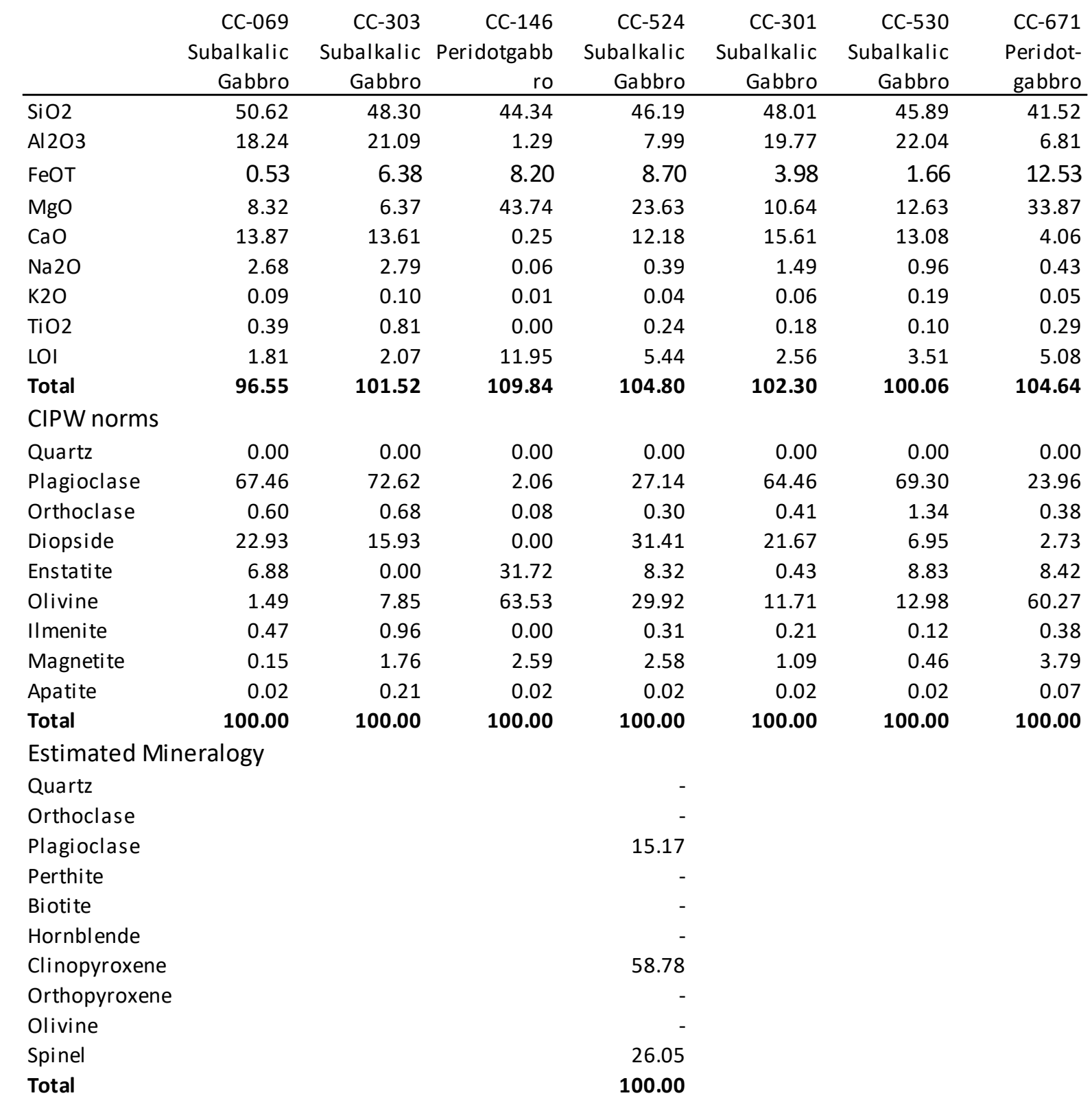




\begin{tabular}{|c|c|c|c|c|c|c|c|c|c|c|c|c|}
\hline & $\begin{array}{l}\text { JK-CGPJ9 } \\
\text { Granite }\end{array}$ & $\begin{array}{l}\text { JK-PGMP1 } \\
\text { Granite }\end{array}$ & $\begin{array}{r}\text { JK-CGRP7 } \\
\text { Granite }\end{array}$ & $\begin{array}{r}\text { JK-CGPJ1 } \\
\text { Quartz } \\
\text { Monzonite } \\
\end{array}$ & $\begin{array}{l}\text { JK-CGCB1 } \\
\text { Granite }\end{array}$ & $\begin{array}{l}\text { JK-HCB1 } \\
\text { Granite }\end{array}$ & $\begin{array}{r}\text { JK-MZPJ1 } \\
\text { Quartz } \\
\text { Monzonite } \\
\end{array}$ & $\begin{array}{r}\text { JK-CMPJ7 } \\
\text { Quartz } \\
\text { Monzonite } \\
\end{array}$ & $\begin{array}{c}\text { JK-GDRP8 } \\
\text { Diorite }\end{array}$ & $\begin{array}{l}\text { JK-GDCB7 } \\
\text { Monzonite }\end{array}$ & $\begin{array}{l}\text { JK-MDPJ8 } \\
\text { Diorite }\end{array}$ & $\begin{array}{r}\text { JK-MDCB5 } \\
\text { Alkalic } \\
\text { Gabbro }\end{array}$ \\
\hline $\mathrm{SiO} 2$ & 75.68 & 70.47 & 75.91 & 70.52 & 77.75 & 76.63 & 66.65 & 64.63 & 57.40 & 60.41 & 57.49 & 50.27 \\
\hline $\mathrm{Al} 2 \mathrm{O} 3$ & 12.54 & 14.51 & 12.61 & 16.31 & 11.94 & 12.44 & 17.23 & 17.88 & 15.77 & 18.23 & 17.77 & 16.58 \\
\hline FeOT & 1.06 & 2.24 & 0.76 & 0.57 & 0.78 & 1.03 & 2.43 & 3.05 & 8.82 & 4.74 & 6.69 & 9.04 \\
\hline $\mathrm{MgO}$ & 0.20 & 0.97 & 0.11 & 0.16 & 0.09 & 0.13 & 0.82 & 1.14 & 3.19 & 2.04 & 2.95 & 6.65 \\
\hline $\mathrm{CaO}$ & 0.33 & 1.32 & 0.37 & 0.39 & 0.03 & 0.03 & 1.41 & 2.92 & 6.46 & 4.40 & 6.28 & 9.16 \\
\hline $\mathrm{Na} 2 \mathrm{O}$ & 3.37 & 4.15 & 4.25 & 5.50 & 4.15 & 4.43 & 6.69 & 6.59 & 4.71 & 5.62 & 3.92 & 3.41 \\
\hline $\mathrm{K} 2 \mathrm{O}$ & 5.89 & 4.08 & 4.30 & 5.74 & 4.49 & 4.64 & 2.43 & 1.69 & 0.77 & 2.01 & 1.61 & 1.42 \\
\hline $\mathrm{TiO} 2$ & 0.20 & 0.38 & 0.14 & 0.15 & 0.12 & 0.17 & 0.35 & 0.42 & 0.99 & 0.65 & 0.84 & 0.82 \\
\hline LOI & 0.22 & 0.98 & 0.14 & 0.31 & 0.15 & 0.22 & 0.86 & 0.43 & 0.46 & 0.46 & 0.92 & 1.32 \\
\hline Total & 99.49 & 99.10 & 98.59 & 99.65 & 99.50 & 99.72 & 98.87 & 98.75 & 98.57 & 98.56 & 98.47 & 98.67 \\
\hline \multicolumn{13}{|l|}{ CIPW norms } \\
\hline Quartz & 32.18 & 26.90 & 33.93 & 15.38 & 35.94 & 32.45 & 14.27 & 11.61 & 9.15 & 7.30 & 10.76 & 0.00 \\
\hline Plagioclase & 30.27 & 42.62 & 38.49 & 48.68 & 35.64 & 37.89 & 65.75 & 71.74 & 64.75 & 69.43 & 63.42 & 60.91 \\
\hline Orthoclase & 36.05 & 25.92 & 26.58 & 35.02 & 27.49 & 28.35 & 15.50 & 10.73 & 5.18 & 12.99 & 10.70 & 9.84 \\
\hline Diopside & 0.00 & 0.00 & 0.00 & 0.00 & 0.00 & 0.00 & 0.00 & 0.00 & 6.71 & 0.69 & 1.41 & 13.35 \\
\hline Enstatite & 1.00 & 3.33 & 0.64 & 0.60 & 0.59 & 0.84 & 3.21 & 4.30 & 9.71 & 6.95 & 10.05 & 3.87 \\
\hline Olivine & 0.00 & 0.00 & 0.00 & 0.00 & 0.00 & 0.00 & 0.00 & 0.00 & 0.00 & 0.00 & 0.00 & 8.04 \\
\hline IImenite & 0.21 & 0.42 & 0.15 & 0.16 & 0.13 & 0.18 & 0.39 & 0.47 & 1.15 & 0.73 & 0.96 & 0.99 \\
\hline Magnetite & 0.26 & 0.57 & 0.19 & 0.14 & 0.19 & 0.25 & 0.63 & 0.78 & 2.38 & 1.23 & 1.79 & 2.52 \\
\hline Apatite & 0.04 & 0.23 & 0.02 & 0.02 & 0.02 & 0.04 & 0.25 & 0.37 & 0.96 & 0.68 & 0.92 & 0.47 \\
\hline Total & 100.00 & 100.00 & 100.00 & 100.00 & 100.00 & 100.00 & 100.00 & 100.00 & 100.00 & 100.00 & 100.00 & 100.00 \\
\hline
\end{tabular}

Quartz

Orthoclase

Plagioclase

Perthite

Biotite

Hornblende

Clinopyroxene

Orthopyroxene

Olivine

Spinel

Total 


\begin{tabular}{|c|c|c|c|c|c|c|c|c|}
\hline & $\begin{array}{r}\text { NN-Pci } \\
\text { Granodiorite }\end{array}$ & $\begin{array}{r}\text { NN-Pcf } \\
\text { Granodiorite }\end{array}$ & $\begin{array}{r}\text { NN-PP2 } \\
\text { Quartz } \\
\text { Monzonite }\end{array}$ & $\begin{array}{l}\text { NN-JF2 } \\
\text { Granite }\end{array}$ & $\begin{array}{r}\text { NN-NC4 } \\
\text { Quartzolite }\end{array}$ & $\begin{array}{l}\text { NN-NC7 } \\
\text { Granite }\end{array}$ & $\begin{array}{l}\text { NN-HSO } \\
\text { Granite }\end{array}$ & $\begin{array}{l}\text { NN-PCV } \\
\text { Granite }\end{array}$ \\
\hline $\mathrm{SiO} 2$ & 69.52 & 69.64 & 67.29 & 71.71 & 87.79 & 74.90 & 71.04 & 74.22 \\
\hline $\mathrm{Al} 2 \mathrm{O} 3$ & 17.38 & 16.11 & 16.18 & 14.76 & 5.72 & 14.16 & 13.33 & 13.66 \\
\hline FeOT & 1.12 & 1.82 & 2.49 & 1.72 & 2.11 & 0.82 & 4.34 & 0.43 \\
\hline MgO & 0.77 & 0.89 & 1.12 & 0.57 & 0.44 & 0.34 & 0.43 & 0.21 \\
\hline $\mathrm{CaO}$ & 2.98 & 3.31 & 1.84 & 1.76 & 0.02 & 1.15 & 0.95 & 0.34 \\
\hline $\mathrm{Na} 2 \mathrm{O}$ & 5.91 & 3.02 & 4.44 & 3.35 & 0.16 & 4.57 & 4.42 & 2.75 \\
\hline $\mathrm{K} 2 \mathrm{O}$ & 1.13 & 3.97 & 4.37 & 4.83 & 2.26 & 3.17 & 3.28 & 6.96 \\
\hline $\mathrm{TiO} 2$ & 0.15 & 0.29 & 0.55 & 0.32 & 0.22 & 0.11 & 0.35 & 0.05 \\
\hline LOI & 0.47 & 0.42 & 0.56 & 0.45 & 0.74 & 0.35 & 0.52 & 0.29 \\
\hline Total & 99.43 & 99.47 & 98.84 & 99.47 & 99.46 & 99.57 & 98.66 & 98.91 \\
\hline \multicolumn{9}{|l|}{ CIPW norms } \\
\hline Quartz & 23.65 & 28.72 & 19.56 & 29.48 & 80.91 & 33.67 & 29.85 & 30.89 \\
\hline Plagioclase & 66.46 & 42.60 & 47.55 & 37.27 & 1.43 & 44.99 & 43.91 & 25.08 \\
\hline Orthoclase & 7.11 & 24.96 & 27.75 & 30.23 & 14.60 & 19.73 & 20.96 & 43.07 \\
\hline Diopside & 0.00 & 0.00 & 0.00 & 0.00 & 0.00 & 0.00 & 0.00 & 0.00 \\
\hline Enstatite & 2.26 & 2.86 & 3.56 & 2.06 & 2.23 & 1.17 & 3.64 & 0.69 \\
\hline Olivine & 0.00 & 0.00 & 0.00 & 0.00 & 0.00 & 0.00 & 0.00 & 0.00 \\
\hline Ilmenite & 0.16 & 0.31 & 0.61 & 0.34 & 0.25 & 0.12 & 0.39 & 0.05 \\
\hline Magnetite & 0.28 & 0.46 & 0.64 & 0.43 & 0.55 & 0.20 & 1.12 & 0.11 \\
\hline Apatite & 0.08 & 0.08 & 0.33 & 0.19 & 0.04 & 0.12 & 0.12 & 0.11 \\
\hline Total & 100.00 & 100.00 & 100.00 & 100.00 & 100.00 & 100.00 & 100.00 & 100.00 \\
\hline \multicolumn{9}{|c|}{ Estimated Mineralogy } \\
\hline Quartz & 18.85 & & & & & 52.91 & & \\
\hline Orthoclase & 39.80 & & & & & - & & \\
\hline Plagioclase & 36.08 & & & & & 46.07 & & \\
\hline Perthite & - & & & & & - & & \\
\hline Biotite & 5.27 & & & & & 1.03 & & \\
\hline Hornblende & - & & & & & - & & \\
\hline Clinopyroxen€ & - & & & & & - & & \\
\hline Orthopyroxen & - & & & & & - & & \\
\hline Olivine & - & & & & & - & & \\
\hline Spinel & - & & & & & - & & \\
\hline Total & 100.00 & & & & & 100.00 & & \\
\hline
\end{tabular}




\begin{tabular}{|c|c|c|c|c|c|c|c|c|c|c|c|c|}
\hline & $\begin{array}{l}\text { DB-001 } \\
\text { Granite }\end{array}$ & $\begin{array}{r}\text { DB-002 } \\
\text { Quartzolite }\end{array}$ & $\begin{array}{l}\text { DB-003 } \\
\text { Granite }\end{array}$ & $\begin{array}{l}\text { DB-010 } \\
\text { Granite }\end{array}$ & $\begin{array}{r}\text { DB-012 } \\
\text { Quartz } \\
\text { Monzonite } \\
\end{array}$ & $\begin{array}{r}\text { DB-013 } \\
\text { Quartz } \\
\text { Monzonite } \\
\end{array}$ & $\begin{array}{r}\text { DB-032 } \\
\text { Alkalic Gabbro }\end{array}$ & $\begin{array}{l}\text { DB-033 } \\
\text { Granite }\end{array}$ & $\begin{array}{l}\text { DB-039 } \\
\text { Granite }\end{array}$ & $\begin{array}{l}\text { DB-048 } \\
\text { Granite }\end{array}$ & $\begin{array}{l}\text { DB-050 } \\
\text { Granite }\end{array}$ & $\begin{array}{l}\text { DB-051 } \\
\text { Granite }\end{array}$ \\
\hline $\mathrm{SiO} 2$ & 77.23 & 89.07 & 75.06 & 76.02 & 64.90 & 65.46 & 49.98 & 73.76 & 77.14 & 77.68 & 77.53 & 70.06 \\
\hline $\mathrm{Al} 2 \mathrm{O} 3$ & 11.53 & 5.53 & 13.96 & 10.48 & 15.39 & 13.98 & 14.74 & 14.46 & 11.40 & 11.22 & 11.51 & 15.53 \\
\hline $\mathrm{FeOT}$ & 2.00 & 0.75 & 1.20 & 5.54 & 2.82 & 3.61 & 12.58 & 1.57 & 3.28 & 2.84 & 2.64 & 2.02 \\
\hline $\mathrm{MgO}$ & 0.11 & 0.72 & 0.37 & 0.14 & 5.44 & 5.98 & 6.35 & 0.39 & 0.08 & 0.51 & 0.57 & 0.54 \\
\hline $\mathrm{CaO}$ & 0.28 & 0.12 & 0.51 & 0.36 & 0.20 & 0.13 & 7.61 & 0.45 & 0.09 & 0.06 & 0.07 & 2.00 \\
\hline $\mathrm{Na} 2 \mathrm{O}$ & 3.68 & 2.35 & 5.03 & 3.93 & 6.46 & 5.34 & 2.41 & 5.88 & 6.58 & 6.22 & 6.32 & 4.12 \\
\hline $\mathrm{K} 2 \mathrm{O}$ & 4.30 & 0.54 & 3.09 & 2.08 & 2.93 & 3.32 & 2.09 & 2.82 & 0.10 & 0.51 & 0.50 & 4.43 \\
\hline $\mathrm{TiO} 2$ & 0.13 & 0.42 & 0.11 & 0.32 & 0.34 & 0.28 & 1.49 & 0.18 & 0.24 & 0.23 & 0.22 & 0.27 \\
\hline LOI & 0.33 & 0.23 & 0.42 & 0.44 & 0.44 & 0.43 & 0.66 & 0.33 & 0.14 & 0.14 & 0.13 & 0.29 \\
\hline Total & 99.59 & 99.73 & 99.75 & 99.31 & 98.92 & 98.53 & 97.91 & 99.84 & 99.05 & 99.41 & 99.49 & 99.26 \\
\hline \multicolumn{13}{|l|}{ CIPW norms } \\
\hline Quartz & 38.27 & 73.52 & 32.72 & 44.04 & 6.99 & 11.93 & 0.80 & 27.51 & 37.96 & 38.47 & 37.74 & 24.02 \\
\hline Plagioclase & 33.01 & 20.83 & 45.91 & 36.91 & 59.34 & 49.42 & 49.69 & 52.35 & 58.08 & 54.56 & 55.40 & 45.14 \\
\hline Orthoclase & 26.60 & 3.35 & 19.31 & 13.35 & 18.97 & 21.79 & 14.82 & 17.55 & 0.62 & 3.17 & 3.11 & 27.60 \\
\hline Diopside & 0.00 & 0.00 & 0.00 & 0.00 & 0.00 & 0.00 & 10.10 & 0.00 & 0.00 & 0.00 & 0.00 & 0.00 \\
\hline Enstatite & 1.46 & 1.57 & 1.51 & 3.88 & 13.54 & 15.55 & 18.82 & 1.71 & 2.19 & 2.80 & 2.80 & 2.29 \\
\hline Olivine & 0.00 & 0.00 & 0.00 & 0.00 & 0.00 & 0.00 & 0.00 & 0.00 & 0.00 & 0.00 & 0.00 & 0.00 \\
\hline Ilmenite & 0.14 & 0.45 & 0.12 & 0.35 & 0.37 & 0.31 & 1.83 & 0.19 & 0.26 & 0.25 & 0.24 & 0.29 \\
\hline Magnetite & 0.50 & 0.19 & 0.30 & 1.43 & 0.74 & 0.95 & 3.59 & 0.39 & 0.83 & 0.71 & 0.66 & 0.51 \\
\hline Apatite & 0.02 & 0.08 & 0.13 & 0.04 & 0.04 & 0.04 & 0.35 & 0.29 & 0.06 & 0.04 & 0.04 & 0.15 \\
\hline Total & 100.00 & 100.00 & 100.00 & 100.00 & 100.00 & 100.00 & 100.00 & 100.00 & 100.00 & 100.00 & 100.00 & 100.00 \\
\hline \multicolumn{13}{|c|}{ Estimated Mineralogy } \\
\hline Quartz & 23.34 & & 18.94 & & 52.39 & & & 26.10 & & & 30.51 & \\
\hline Orthoclase & 49.80 & & 64.11 & & - & & & - & & & - & \\
\hline Plagioclase & 25.58 & & 13.09 & & 31.07 & & & - & & & 60.85 & \\
\hline Perthite & - & & - & & - & & & 68.16 & & & - & \\
\hline Biotite & 1.28 & & 3.86 & & 16.55 & & & 5.74 & & & 8.65 & \\
\hline Hornblende & - & & - & & - & & & - & & & - & \\
\hline Clinopyroxen€ & - & & - & & - & & & - & & & - & \\
\hline Orthopyroxen & - & & - & & - & & & - & & & - & \\
\hline Olivine & - & & - & & - & & & - & & & - & \\
\hline Spinel & - & & - & & - & & & - & & & - & \\
\hline Total & 100.00 & & 100.00 & & 100.00 & & & 100.00 & & & 100.00 & \\
\hline
\end{tabular}




\begin{tabular}{|c|c|c|c|c|c|c|c|c|c|c|c|}
\hline & $\begin{array}{l}\text { MD-004 } \\
\text { Granite }\end{array}$ & $\begin{array}{l}\text { MD-006 } \\
\text { Granite }\end{array}$ & $\begin{array}{l}\text { MD-008 } \\
\text { Granite }\end{array}$ & $\begin{array}{l}\text { MD-011 } \\
\text { Granite }\end{array}$ & $\begin{array}{r}\text { MD-012 } \\
\text { Gabbroic } \\
\text { Diorite } \\
\end{array}$ & $\begin{array}{l}\text { MD-013 } \\
\text { Granite }\end{array}$ & $\begin{array}{r}\text { MD-014 } \\
\text { Quartz } \\
\text { Monzonite } \\
\end{array}$ & $\begin{array}{r}\text { MD-015 } \\
\text { Quartz } \\
\text { Monzonite } \\
\end{array}$ & $\begin{array}{l}\text { MD-016 } \\
\text { Granite }\end{array}$ & $\begin{array}{l}\text { MD-018 } \\
\text { Granite }\end{array}$ & $\begin{array}{l}\text { MD-019 } \\
\text { Granite }\end{array}$ \\
\hline $\mathrm{SiO} 2$ & 70.15 & 76.97 & 75.18 & 75.28 & 55.12 & 75.65 & 68.36 & 64.79 & 75.75 & 76.17 & 75.70 \\
\hline $\mathrm{Al} 2 \mathrm{O} 3$ & 14.34 & 11.93 & 13.62 & 12.93 & 13.33 & 12.66 & 16.75 & 16.14 & 13.68 & 13.11 & 13.00 \\
\hline FeOT & 2.65 & 1.50 & 0.42 & 1.15 & 6.91 & 1.00 & 1.83 & 3.74 & 0.61 & 0.55 & 0.50 \\
\hline $\mathrm{MgO}$ & 1.19 & 0.17 & 0.11 & 0.20 & 7.34 & 0.31 & 0.64 & 1.52 & 0.17 & 0.18 & 0.15 \\
\hline $\mathrm{CaO}$ & 2.35 & 0.33 & 0.42 & 0.20 & 8.51 & 0.83 & 2.43 & 3.57 & 0.98 & 0.72 & 0.66 \\
\hline $\mathrm{Na} 2 \mathrm{O}$ & 3.10 & 2.68 & 4.44 & 3.16 & 2.77 & 3.62 & 4.87 & 4.55 & 3.74 & 3.77 & 2.99 \\
\hline K2O & 4.82 & 6.17 & 4.45 & 6.23 & 2.44 & 4.69 & 3.65 & 3.38 & 4.55 & 4.79 & 5.94 \\
\hline $\mathrm{TiO} 2$ & 0.37 & 0.16 & 0.03 & 0.17 & 0.73 & 0.16 & 0.25 & 0.56 & 0.09 & 0.07 & 0.07 \\
\hline LOI & 0.37 & 0.18 & 0.42 & 0.30 & 1.34 & 0.27 & 0.47 & 0.32 & 0.27 & 0.32 & 0.23 \\
\hline Total & 99.33 & 100.09 & 99.09 & 99.63 & 98.49 & 99.18 & 99.24 & 98.56 & 99.84 & 99.68 & 99.24 \\
\hline \multicolumn{12}{|l|}{ CIPW norms } \\
\hline Quartz & 26.82 & 36.19 & 31.33 & 32.10 & 4.14 & 34.41 & 19.91 & 15.93 & 34.29 & 34.00 & 33.86 \\
\hline Plagioclase & 37.78 & 24.28 & 40.33 & 28.02 & 44.79 & 35.00 & 53.97 & 54.18 & 36.72 & 35.63 & 28.82 \\
\hline Orthoclase & 30.09 & 37.69 & 27.50 & 38.32 & 16.88 & 28.89 & 22.81 & 21.51 & 28.03 & 29.39 & 36.50 \\
\hline Diopside & 0.00 & 0.00 & 0.00 & 0.00 & 17.40 & 0.00 & 0.00 & 1.78 & 0.00 & 0.00 & 0.00 \\
\hline Enstatite & 4.03 & 1.26 & 0.68 & 1.04 & 13.48 & 1.22 & 2.43 & 4.58 & 0.69 & 0.73 & 0.60 \\
\hline Olivine & 0.00 & 0.00 & 0.00 & 0.00 & 0.00 & 0.00 & 0.00 & 0.00 & 0.00 & 0.00 & 0.00 \\
\hline IImenite & 0.40 & 0.17 & 0.03 & 0.18 & 0.88 & 0.17 & 0.27 & 0.62 & 0.10 & 0.07 & 0.07 \\
\hline Magnetite & 0.67 & 0.37 & 0.10 & 0.29 & 1.92 & 0.25 & 0.46 & 0.96 & 0.15 & 0.14 & 0.12 \\
\hline Apatite & 0.21 & 0.04 & 0.02 & 0.04 & 0.51 & 0.06 & 0.15 & 0.43 & 0.02 & 0.04 & 0.02 \\
\hline Total & 100.00 & 100.00 & 100.00 & 100.00 & 100.00 & 100.00 & 100.00 & 100.00 & 100.00 & 100.00 & 100.00 \\
\hline \multicolumn{12}{|c|}{ Estimated Mineralogy } \\
\hline Quartz & 46.69 & 18.69 & & 11.35 & - & 27.72 & 20.00 & 35.06 & 40.00 & & \\
\hline Orthoclase & 31.67 & 78.21 & & 86.48 & 12.61 & 63.30 & 20.00 & 14.83 & 15.00 & & \\
\hline Plagioclase & - & - & & 1.06 & 3.98 & 7.60 & 50.00 & 26.41 & 35.00 & & \\
\hline Perthite & 16.28 & 1.69 & & - & - & - & - & - & - & & \\
\hline Biotite & 5.36 & 1.41 & & 1.11 & - & 1.14 & 5.00 & 13.70 & - & & \\
\hline Hornblende & - & - & & - & 83.41 & - & 5.00 & 10.00 & - & & \\
\hline Clinopyroxen $\epsilon$ & - & - & & - & - & - & - & - & - & & \\
\hline Orthopyroxen & - & - & & - & - & - & - & - & - & & \\
\hline Olivine & - & - & & - & - & - & - & - & - & & \\
\hline Spinel & - & - & & - & - & - & - & - & - & & \\
\hline Total & 100.00 & 100.00 & & 100.00 & 100.00 & 99.75 & 100.00 & 100.00 & 90.00 & & 92 \\
\hline
\end{tabular}


MD-021 MD-023

\begin{tabular}{lrr} 
& Monzonite & Granite \\
\hline $\mathrm{SiO2}$ & 55.31 & 69.39 \\
$\mathrm{Al} 2 \mathrm{O} 3$ & 18.41 & 14.76 \\
$\mathrm{FeOT}$ & 6.95 & 2.94 \\
$\mathrm{MgO}$ & 2.96 & 1.16 \\
$\mathrm{CaO}$ & 5.15 & 2.62 \\
$\mathrm{Na2O}$ & 4.96 & 3.97 \\
$\mathrm{~K} 2 \mathrm{O}$ & 2.97 & 3.99 \\
$\mathrm{TiO} 2$ & 0.89 & 0.41 \\
LOI & 0.63 & 0.27 \\
Total & $\mathbf{9 8 . 2 3}$ & 99.51 \\
CIPW norms & & \\
Quartz & 0.00 & 23.78 \\
Plagioclase & 65.53 & 45.22 \\
Orthoclase & 19.59 & 24.91 \\
Diopside & 2.77 & 1.03 \\
Enstatite & 6.23 & 3.67 \\
Olivine & 2.30 & 0.00 \\
Ilmenite & 1.01 & 0.44 \\
Magnetite & 1.84 & 0.74 \\
Apatite & 0.73 & 0.21 \\
Total & $\mathbf{1 0 0 . 0 0}$ & $\mathbf{1 0 0 . 0 0}$ \\
Estimated & &
\end{tabular}

Estimated Mineralogy

$\begin{array}{lrr}\text { Quartz } & 5.00 & 35.29 \\ \text { Orthoclase } & - & 53.42 \\ \text { Plagioclase } & 10.00 & 2.73 \\ \text { Perthite } & 5.00 & - \\ \text { Biotite } & 15.00 & 5.00 \\ \text { Hornblende } & 60.00 & 3.91 \\ \text { Clinopyroxen } & - & - \\ \text { Orthopyroxen } & - & - \\ \text { Olivine } & - & - \\ \text { Spinel } & - & - \\ \text { Total } & \mathbf{9 5 . 0 0} & \mathbf{1 0 0 . 3 6}\end{array}$




\begin{tabular}{|c|c|c|c|c|c|c|}
\hline & $\mathrm{MH}-30$ & $\mathrm{MH}-13$ & PL-H64 & PL-A23 & PL-K33 & PL-J3 \\
\hline & Granite & Granite & Granite & Granite & Granite & Granite \\
\hline $\mathrm{SiO} 2$ & 74.16 & 73.38 & 73.35 & 71.74 & 73.70 & 71.22 \\
\hline $\mathrm{Al} 2 \mathrm{O} 3$ & 14.56 & 14.31 & 14.22 & 13.87 & 14.12 & 14.96 \\
\hline $\mathrm{FeOT}$ & 1.03 & 1.14 & 1.30 & 2.85 & 2.25 & 2.38 \\
\hline $\mathrm{MgO}$ & 0.31 & 0.45 & 0.48 & 0.73 & 0.60 & 0.68 \\
\hline $\mathrm{CaO}$ & 1.19 & 1.13 & 0.49 & 0.81 & 0.74 & 0.73 \\
\hline $\mathrm{Na} 2 \mathrm{O}$ & 4.20 & 4.98 & 3.89 & 3.43 & 0.92 & 3.39 \\
\hline K2O & 4.00 & 3.15 & 5.28 & 5.04 & 5.69 & 5.46 \\
\hline $\mathrm{TiO} 2$ & 0.17 & 0.20 & 0.24 & 0.54 & 0.18 & 0.34 \\
\hline LOI & & & 0.61 & 0.52 & 1.15 & 0.68 \\
\hline Total & 99.62 & 98.74 & 99.86 & 99.53 & 99.35 & 99.84 \\
\hline \multicolumn{7}{|l|}{ CIPW norms } \\
\hline Quartz & 30.96 & 29.58 & 29.01 & 29.65 & 47.24 & 28.31 \\
\hline Plagioclase & 42.13 & 48.42 & 35.30 & 33.60 & 10.26 & 32.71 \\
\hline Orthoclase & 26.20 & 20.80 & 33.13 & 32.27 & 38.24 & 34.98 \\
\hline Diopside & 0.00 & 0.00 & 0.00 & 0.00 & 0.00 & 0.00 \\
\hline Enstatite & 0.63 & 0.95 & 1.68 & 2.96 & 2.81 & 2.73 \\
\hline Olivine & 0.00 & 0.00 & 0.00 & 0.00 & 0.00 & 0.00 \\
\hline Ilmenite & 0.01 & 0.01 & 0.25 & 0.59 & 0.21 & 0.37 \\
\hline Magnetite & 0.00 & 0.00 & 0.33 & 0.73 & 0.60 & 0.61 \\
\hline Apatite & 0.06 & 0.25 & 0.29 & 0.21 & 0.64 & 0.29 \\
\hline Total & 100.00 & 100.00 & 100.00 & 100.00 & 100.00 & 100.00 \\
\hline \multicolumn{7}{|c|}{ Estimated Mineralogy } \\
\hline Quartz & & & 45.02 & 44.41 & & \\
\hline Orthoclase & & & 30.92 & 45.14 & & \\
\hline Plagioclase & & & 20.12 & 6.36 & & \\
\hline Perthite & & & - & - & & \\
\hline Biotite & & & 3.95 & 4.09 & & \\
\hline Hornblende & & & - & - & & \\
\hline Clinopyroxene & & & - & - & & \\
\hline Orthopyroxene & & & - & - & & \\
\hline Olivine & & & - & - & & \\
\hline Spinel & & & - & - & & \\
\hline Total & & & 100.00 & 100.00 & & \\
\hline
\end{tabular}




\begin{tabular}{|c|c|c|c|c|c|c|c|}
\hline & DH-GA & DH-KG & $\mathrm{DH}-\mathrm{P}$ & $\mathrm{DH}-\mathrm{BC}$ & $\mathrm{DH}-\mathrm{A}$ & DH-BA & $\mathrm{DH}-\mathrm{M} 2$ \\
\hline & Granite & Granite & Granite & Granite & Granite & Granite & Granite \\
\hline $\mathrm{SiO} 2$ & 76.25 & 75.45 & 73.93 & 73.15 & 76.83 & 75.48 & 73.55 \\
\hline $\mathrm{Al} 2 \mathrm{O} 3$ & 12.90 & 12.01 & 12.67 & 12.95 & 11.84 & 12.20 & 13.54 \\
\hline $\mathrm{FeOT}$ & 2.16 & 1.33 & 3.52 & 2.46 & 1.74 & 1.78 & 2.06 \\
\hline $\mathrm{MgO}$ & 0.00 & 0.52 & 0.71 & 0.15 & 0.08 & 0.06 & 0.24 \\
\hline $\mathrm{CaO}$ & 0.90 & 0.01 & 2.67 & 0.90 & 0.23 & 0.57 & 0.79 \\
\hline $\mathrm{Na} 2 \mathrm{O}$ & 4.74 & 1.12 & 1.99 & 3.20 & 3.80 & 3.64 & 3.23 \\
\hline $\mathrm{K} 2 \mathrm{O}$ & 2.85 & 7.28 & 3.22 & 5.02 & 4.67 & 4.67 & 5.37 \\
\hline $\mathrm{TiO} 2$ & 0.91 & 0.21 & 0.35 & 0.28 & 0.12 & 0.17 & 0.24 \\
\hline LOI & 0.30 & 0.93 & 1.22 & 0.52 & 0.22 & 0.49 & 0.76 \\
\hline Total & 101.01 & 98.86 & 100.28 & 98.63 & 99.53 & 99.06 & 99.78 \\
\hline \multicolumn{8}{|l|}{ CIPW norms } \\
\hline Quartz & 35.20 & 40.67 & 42.60 & 32.75 & 35.61 & 34.63 & 31.67 \\
\hline Plagioclase & 44.91 & 9.97 & 31.01 & 32.54 & 33.75 & 34.34 & 31.98 \\
\hline Orthoclase & 17.87 & 46.89 & 21.24 & 31.96 & 28.80 & 29.16 & 33.81 \\
\hline Diopside & 0.00 & 0.00 & 0.00 & 0.00 & 0.00 & 0.00 & 0.00 \\
\hline Enstatite & 0.53 & 1.91 & 3.87 & 1.84 & 1.27 & 1.25 & 1.76 \\
\hline Olivine & 0.00 & 0.00 & 0.00 & 0.00 & 0.00 & 0.00 & 0.00 \\
\hline IImenite & 0.96 & 0.22 & 0.38 & 0.30 & 0.13 & 0.18 & 0.26 \\
\hline Magnetite & 0.53 & 0.33 & 0.90 & 0.62 & 0.43 & 0.44 & 0.51 \\
\hline Apatite & 0.00 & 0.00 & 0.00 & 0.00 & 0.00 & 0.00 & 0.00 \\
\hline Total & 100.00 & 100.00 & 100.00 & 100.00 & 100.00 & 100.00 & 100.00 \\
\hline \multicolumn{8}{|c|}{ Estimated Mineralogy } \\
\hline Quartz & 35.97 & 41.53 & & 32.17 & 26.78 & 32.41 & \\
\hline Orthoclase & 32.57 & - & & - & - & - & \\
\hline Plagioclase & 31.27 & 53.56 & & 67.83 & 73.22 & 13.92 & \\
\hline Perthite & - & - & & - & - & 51.72 & \\
\hline Biotite & 0.19 & 4.91 & & - & - & 1.95 & \\
\hline Hornblende & - & - & & - & - & - & \\
\hline Clinopyroxen€ & - & - & & - & - & - & \\
\hline Orthopyroxen & - & - & & - & - & - & \\
\hline Olivine & - & - & & - & - & - & \\
\hline Spinel & - & - & & - & - & - & \\
\hline Total & 100.00 & 100.00 & & 100.00 & 100.00 & 100.00 & \\
\hline
\end{tabular}




\begin{tabular}{|c|c|c|c|c|c|c|c|c|c|c|c|}
\hline & $\begin{array}{l}\text { GJ-013 } \\
\text { Granite }\end{array}$ & $\begin{array}{l}\text { GJ-016 } \\
\text { Syenite }\end{array}$ & $\begin{array}{r}\text { GJ-022 } \\
\text { Quartz } \\
\text { Monzonite } \\
\end{array}$ & $\begin{array}{r}\text { GJ-023 } \\
\text { Quartz } \\
\text { Monzonite } \\
\end{array}$ & $\begin{array}{r}\text { GJ-037 } \\
\text { Quartz } \\
\text { Monzonite } \\
\end{array}$ & $\begin{array}{l}\text { GJ-045 } \\
\text { Syenite }\end{array}$ & $\begin{array}{r}\text { GJ-050 } \\
\text { Quartz } \\
\text { Monzonite } \\
\end{array}$ & $\begin{array}{r}\text { GJ-065 } \\
\text { Quartz } \\
\text { Monzonite } \\
\end{array}$ & $\begin{array}{r}\text { GJ-067 } \\
\text { Quartz } \\
\text { Monzonite } \\
\end{array}$ & $\begin{array}{l}\text { GJ-086 } \\
\text { Syenite }\end{array}$ & $\begin{array}{l}\text { GJ-101 } \\
\text { Syenite }\end{array}$ \\
\hline $\mathrm{SiO} 2$ & 70.12 & 65.74 & 67.94 & 68.16 & 68.67 & 65.84 & 65.08 & 63.76 & 64.37 & 64.86 & 62.65 \\
\hline $\mathrm{Al} 2 \mathrm{O} 3$ & 14.23 & 17.19 & 15.58 & 16.27 & 15.42 & 16.67 & 15.49 & 17.36 & 18.28 & 17.63 & 16.30 \\
\hline FeOT & 2.56 & 1.35 & 1.50 & 1.08 & 1.62 & 2.23 & 3.39 & 2.24 & 1.84 & 1.60 & 3.17 \\
\hline $\mathrm{MgO}$ & 1.09 & 0.50 & 0.50 & 0.29 & 0.52 & 0.45 & 2.53 & 1.66 & 0.94 & 0.26 & 1.12 \\
\hline $\mathrm{CaO}$ & 3.38 & 1.95 & 1.82 & 1.19 & 1.83 & 1.74 & 2.49 & 5.59 & 4.19 & 0.56 & 3.18 \\
\hline $\mathrm{Na} 2 \mathrm{O}$ & 6.46 & 7.76 & 7.18 & 6.82 & 5.08 & 5.22 & 7.77 & 6.49 & 7.52 & 7.11 & 3.87 \\
\hline $\mathrm{K} 2 \mathrm{O}$ & 0.81 & 3.70 & 3.69 & 4.78 & 5.05 & 5.94 & 0.61 & 1.13 & 1.16 & 5.53 & 7.68 \\
\hline $\mathrm{TiO} 2$ & 0.30 & 0.18 & 0.20 & 0.15 & 0.24 & 0.35 & 0.36 & 0.53 & 0.21 & 0.21 & 0.56 \\
\hline LOI & 0.47 & 1.38 & 1.48 & 1.01 & 0.80 & 0.37 & 1.03 & 0.56 & 0.32 & 0.52 & 0.27 \\
\hline Total & 99.42 & 99.75 & 99.89 & 99.75 & 99.23 & 98.81 & 98.75 & 99.32 & 98.83 & 98.28 & 98.80 \\
\hline \multicolumn{12}{|l|}{ CIPW norms } \\
\hline Quartz & 22.33 & 2.99 & 9.28 & 8.35 & 15.91 & 8.69 & 9.28 & 9.89 & 7.26 & 0.84 & 4.21 \\
\hline Plagioclase & 64.36 & 69.22 & 62.39 & 58.74 & 48.44 & 49.82 & 75.57 & 72.59 & 78.83 & 61.66 & 38.34 \\
\hline Orthoclase & 5.13 & 23.23 & 23.33 & 29.70 & 31.39 & 36.95 & 3.91 & 7.18 & 7.28 & 34.41 & 48.14 \\
\hline Diopside & 5.93 & 3.90 & 4.57 & 2.84 & 2.74 & 2.18 & 3.82 & 7.87 & 4.75 & 1.55 & 6.10 \\
\hline Enstatite & 1.11 & 0.00 & 0.00 & 0.00 & 0.69 & 1.17 & 5.78 & 0.97 & 0.89 & 0.85 & 1.14 \\
\hline Olivine & 0.00 & 0.00 & 0.00 & 0.00 & 0.00 & 0.00 & 0.00 & 0.00 & 0.00 & 0.00 & 0.00 \\
\hline Ilmenite & 0.33 & 0.19 & 0.21 & 0.16 & 0.25 & 0.37 & 0.40 & 0.58 & 0.23 & 0.22 & 0.61 \\
\hline Magnetite & 0.65 & 0.34 & 0.11 & 0.13 & 0.41 & 0.56 & 0.88 & 0.58 & 0.47 & 0.34 & 0.80 \\
\hline Apatite & 0.16 & 0.13 & 0.10 & 0.08 & 0.17 & 0.25 & 0.36 & 0.34 & 0.29 & 0.13 & 0.66 \\
\hline Total & 100.00 & 100.00 & 100.00 & 100.00 & 100.00 & 100.00 & 100.00 & 100.00 & 100.00 & 100.00 & 100.00 \\
\hline \multicolumn{12}{|c|}{ Estimated Mineralogy } \\
\hline Quartz & & 2.00 & 10.00 & 5.00 & & & 5.00 & 4.00 & 2.00 & - & \\
\hline Orthoclase & & 85.00 & 75.00 & - & & & 15.00 & - & - & 95.00 & \\
\hline Plagioclase & & - & - & - & & & 55.00 & 76.00 & 85.00 & - & \\
\hline Perthite & & - & - & 85.00 & & & - & - & - & - & \\
\hline Biotite & & 3.00 & - & 8.00 & & & - & - & - & - & \\
\hline Hornblende & & - & 4.00 & - & & & 20.00 & 7.00 & 1.00 & - & \\
\hline Clinopyroxene & & 6.00 & 6.00 & - & & & 5.00 & 9.00 & 9.00 & 5.00 & \\
\hline Orthopyroxene & & - & - & - & & & - & - & - & - & \\
\hline Olivine & & - & - & - & & & - & - & - & - & \\
\hline Spinel & & - & - & - & & & - & - & - & - & \\
\hline Total & & 96.00 & 95.00 & 98.00 & & & 100.00 & 96.00 & 97.00 & 100.00 & \\
\hline
\end{tabular}




\begin{tabular}{|c|c|c|c|c|c|c|c|c|c|c|c|}
\hline & $\begin{array}{l}\text { GJ-105 } \\
\text { Granite }\end{array}$ & $\begin{array}{l}\text { GJ-109 } \\
\text { Granite }\end{array}$ & $\begin{array}{c}\text { GJ-111 } \\
\text { Granite }\end{array}$ & $\begin{array}{l}\text { GJ-120 } \\
\text { Syenite }\end{array}$ & $\begin{array}{r}\text { GJ-127 } \\
\text { Quartz } \\
\text { Monzonite } \\
\end{array}$ & $\begin{array}{r}\text { GJ-128 } \\
\text { Quartz } \\
\text { Monzonite } \\
\end{array}$ & $\begin{array}{r}\text { GJ-129 } \\
\text { Quartz } \\
\text { Monzonite } \\
\end{array}$ & $\begin{array}{l}\text { GJ-158 } \\
\text { Syenite }\end{array}$ & $\begin{array}{l}\text { GJ-163 } \\
\text { Syenite }\end{array}$ & $\begin{array}{l}\text { GJ-171 } \\
\text { Syenite }\end{array}$ & $\begin{array}{r}\text { GJ-182 } \\
\text { Quartz } \\
\text { Monzonite } \\
\end{array}$ \\
\hline $\mathrm{SiO} 2$ & 71.40 & 72.95 & 69.74 & 63.31 & 68.97 & 69.31 & 69.65 & 59.36 & 63.78 & 64.77 & 64.24 \\
\hline $\mathrm{Al} 2 \mathrm{O} 3$ & 13.97 & 13.62 & 12.58 & 14.42 & 14.21 & 14.79 & 14.73 & 15.40 & 17.67 & 16.07 & 15.63 \\
\hline FeOT & 1.20 & 1.04 & 2.94 & 3.28 & 1.80 & 1.64 & 1.50 & 5.77 & 1.85 & 2.14 & 3.04 \\
\hline $\mathrm{MgO}$ & 0.25 & 0.40 & 0.90 & 1.73 & 0.51 & 0.49 & 0.39 & 1.59 & 0.66 & 0.42 & 2.39 \\
\hline $\mathrm{CaO}$ & 1.31 & 1.55 & 2.67 & 3.79 & 2.44 & 1.72 & 1.89 & 3.72 & 1.79 & 2.04 & 4.14 \\
\hline $\mathrm{Na} 2 \mathrm{O}$ & 4.94 & 4.00 & 3.72 & 4.67 & 5.37 & 5.60 & 5.95 & 5.63 & 6.78 & 7.62 & 5.71 \\
\hline $\mathrm{K} 2 \mathrm{O}$ & 5.10 & 5.38 & 5.61 & 7.06 & 4.92 & 5.02 & 4.60 & 5.44 & 5.52 & 4.32 & 2.64 \\
\hline TiO2 & 0.23 & 0.39 & 0.24 & 0.08 & 0.36 & 0.37 & 0.33 & 0.90 & 0.34 & 0.26 & 0.36 \\
\hline LOI & 0.18 & 0.67 & 0.32 & 0.34 & 0.62 & 0.28 & 0.52 & 0.26 & 0.32 & 1.35 & 0.58 \\
\hline Total & 98.58 & 100.00 & 98.72 & 98.68 & 99.20 & 99.22 & 99.56 & 98.07 & 98.71 & 98.99 & 98.73 \\
\hline \multicolumn{12}{|l|}{ CIPW norms } \\
\hline Quartz & 21.23 & 26.12 & 21.91 & 2.77 & 15.60 & 14.73 & 14.88 & 0.00 & 0.00 & 2.93 & 10.55 \\
\hline Plagioclase & 43.87 & 37.56 & 33.77 & 37.53 & 47.83 & 49.20 & 52.06 & 48.31 & 59.79 & 62.98 & 60.40 \\
\hline Orthoclase & 31.71 & 33.06 & 35.26 & 45.99 & 31.23 & 31.32 & 28.91 & 36.12 & 34.52 & 28.04 & 16.91 \\
\hline Diopside & 2.47 & 2.44 & 7.04 & 10.89 & 4.26 & 3.78 & 3.29 & 11.44 & 4.44 & 5.50 & 6.60 \\
\hline Enstatite & 0.00 & 0.00 & 0.51 & 1.76 & 0.00 & 0.00 & 0.00 & 0.00 & 0.00 & 0.00 & 3.88 \\
\hline Olivine & 0.00 & 0.00 & 0.00 & 0.00 & 0.00 & 0.00 & 0.00 & 1.05 & 0.21 & 0.00 & 0.00 \\
\hline IImenite & 0.24 & 0.41 & 0.26 & 0.09 & 0.39 & 0.39 & 0.36 & 1.03 & 0.36 & 0.30 & 0.40 \\
\hline Magnetite & 0.30 & 0.26 & 0.74 & 0.00 & 0.46 & 0.41 & 0.34 & 1.54 & 0.47 & 0.00 & 0.78 \\
\hline Apatite & 0.17 & 0.15 & 0.51 & 0.97 & 0.23 & 0.15 & 0.17 & 0.51 & 0.21 & 0.26 & 0.47 \\
\hline Total & 100.00 & 100.00 & 100.00 & 100.00 & 100.00 & 100.00 & 100.00 & 100.00 & 100.00 & 100.00 & 100.00 \\
\hline \multicolumn{12}{|c|}{ Estimated Mineralogy } \\
\hline Quartz & & 20.00 & & - & & 9.00 & & & & & \\
\hline Orthoclase & & 50.00 & & 90.00 & & 86.00 & & & & & \\
\hline Plagioclase & & 21.00 & & 1.00 & & - & & & & & \\
\hline Perthite & & - & & - & & - & & & & & \\
\hline Biotite & & - & & - & & - & & & & & \\
\hline Hornblende & & 1.00 & & 1.00 & & - & & & & & \\
\hline Clinopyroxene & & 8.00 & & 8.00 & & 3.00 & & & & & \\
\hline Orthopyroxene & & - & & - & & - & & & & & \\
\hline Olivine & & - & & - & & - & & & & & \\
\hline Spinel & & - & & - & & - & & & & & \\
\hline Total & & 100.00 & & 100.00 & & 98.00 & & & & & \\
\hline
\end{tabular}




\begin{tabular}{|c|c|c|c|c|c|c|c|c|c|}
\hline & $\begin{array}{l}\text { HF-004 } \\
\text { Peridot- } \\
\text { gabbro }\end{array}$ & $\begin{array}{l}\text { HF-006 } \\
\text { Alkalic } \\
\text { Gabbro }\end{array}$ & $\begin{array}{r}\text { HF-007 } \\
\text { Monzogabbro }\end{array}$ & $\begin{array}{l}\text { HF-008 } \\
\text { Alkalic } \\
\text { Gabbro }\end{array}$ & $\begin{array}{r}\text { HF-010 } \\
\text { Quartz } \\
\text { Monzonite }\end{array}$ & $\begin{array}{r}\text { HF-015 } \\
\text { Granodiorite }\end{array}$ & $\begin{array}{r}\text { HF-017 } \\
\text { Monzogabbro }\end{array}$ & $\begin{array}{r}\text { HF-018 } \\
\text { Monzodiorite }\end{array}$ & $\begin{array}{r}\text { HF-035b } \\
\text { Monzodiorite }\end{array}$ \\
\hline $\mathrm{SiO} 2$ & 44.28 & 49.67 & 51.04 & 46.25 & 62.77 & 67.39 & 50.25 & 52.59 & 54.92 \\
\hline $\mathrm{Al} 2 \mathrm{O} 3$ & 11.50 & 13.78 & 13.92 & 12.29 & 14.27 & 13.64 & 14.44 & 12.12 & 12.31 \\
\hline FeOT & 20.09 & 13.00 & 12.04 & 15.42 & 6.58 & 6.14 & 12.42 & 14.30 & 7.41 \\
\hline $\mathrm{MgO}$ & 6.37 & 6.31 & 6.24 & 5.37 & 1.85 & 0.78 & 6.62 & 3.09 & 4.59 \\
\hline $\mathrm{CaO}$ & 9.81 & 8.40 & 7.23 & 11.50 & 1.53 & 2.62 & 5.98 & 6.58 & 5.10 \\
\hline $\mathrm{Na} 2 \mathrm{O}$ & 2.02 & 3.47 & 4.06 & 3.61 & 3.05 & 6.68 & 4.65 & 6.24 & 1.72 \\
\hline K2O & 0.39 & 1.00 & 1.31 & 0.11 & 6.30 & 0.38 & 1.83 & 0.53 & 4.48 \\
\hline $\mathrm{TiO} 2$ & 2.37 & 1.47 & 1.54 & 2.94 & 1.03 & 0.85 & 1.40 & 2.27 & 0.79 \\
\hline LOI & 0.60 & 1.28 & 1.01 & 0.89 & 0.87 & 0.34 & 0.73 & 0.28 & 7.13 \\
\hline Total & 97.43 & 98.38 & 98.39 & 98.38 & 98.25 & 98.82 & 98.32 & 98.00 & 98.45 \\
\hline \multicolumn{10}{|c|}{ CIPW norms } \\
\hline Quartz & 0.00 & 0.00 & 0.00 & 0.00 & 14.50 & 20.94 & 0.00 & 0.00 & 12.96 \\
\hline Plagioclase & 46.67 & 56.08 & 57.47 & 54.34 & 33.12 & 66.46 & 56.58 & 64.05 & 31.07 \\
\hline Orthoclase & 2.98 & 7.13 & 9.25 & 0.80 & 41.07 & 2.43 & 13.06 & 3.77 & 32.07 \\
\hline Diopside & 21.81 & 16.29 & 14.03 & 29.73 & 0.00 & 3.70 & 11.76 & 20.04 & 6.32 \\
\hline Enstatite & 16.55 & 10.81 & 8.32 & 0.00 & 7.69 & 3.44 & 0.00 & 0.00 & 13.08 \\
\hline Olivine & 2.51 & 3.75 & 5.24 & 5.83 & 0.00 & 0.00 & 12.97 & 4.41 & 0.00 \\
\hline Ilmenite & 3.12 & 1.82 & 1.88 & 3.80 & 1.16 & 0.95 & 1.72 & 2.78 & 0.98 \\
\hline Magnetite & 6.16 & 3.74 & 3.41 & 4.62 & 1.73 & 1.60 & 3.57 & 4.07 & 2.13 \\
\hline Apatite & 0.19 & 0.37 & 0.39 & 0.88 & 0.72 & 0.48 & 0.33 & 0.88 & 1.37 \\
\hline Total & 100.00 & 100.00 & 100.00 & 100.00 & 100.00 & 100.00 & 100.00 & 100.00 & 100.00 \\
\hline
\end{tabular}

Estimated Mineralogy

Quartz

Orthoclase

Plagioclase

Perthite

Biotite

Hornblende

Clinopyroxene

Orthopyroxene

Olivine

Spinel

Total 
HF-036

HF-039

HF-043

HF-049

HF-050

HF-053

HF-058

HF-059

HF-035

Monzogabbro

Monzodiorite

Monzonite

Alkalic Alkalic Gabbro

Monzodiorite

Monzodiorite Monzodiorite

\begin{tabular}{|c|c|c|c|c|c|c|c|c|c|}
\hline \multirow[b]{2}{*}{$\mathrm{SiO} 2$} & \\
\hline & 49.98 & 52.57 & 57.53 & 50.76 & 47.66 & 49.16 & 52.73 & 51.74 & 54.60 \\
\hline $\mathrm{Al} 2 \mathrm{O} 3$ & 11.32 & 14.61 & 13.67 & 13.45 & 15.56 & 15.74 & 12.77 & 12.46 & 12.31 \\
\hline FeOT & 11.05 & 9.58 & 4.44 & 13.93 & 8.65 & 9.79 & 8.71 & 9.85 & 7.41 \\
\hline MgO & 7.86 & 4.93 & 3.58 & 5.52 & 9.08 & 7.80 & 4.99 & 4.30 & 4.59 \\
\hline $\mathrm{CaO}$ & 4.56 & 5.64 & 8.78 & 7.76 & 11.08 & 8.03 & 5.00 & 6.04 & 5.10 \\
\hline $\mathrm{Na} 2 \mathrm{O}$ & 1.53 & 6.59 & 6.57 & 4.68 & 3.28 & 4.60 & 1.69 & 1.33 & 1.72 \\
\hline K2O & 4.10 & 0.81 & 1.04 & 0.35 & 0.43 & 0.11 & 5.72 & 4.26 & 4.48 \\
\hline $\mathrm{TiO} 2$ & 1.99 & 1.91 & 2.37 & 1.48 & 0.68 & 0.80 & 1.76 & 1.88 & 0.79 \\
\hline LOI & 4.08 & 1.61 & 0.38 & 0.30 & 2.29 & 2.72 & 4.13 & 5.79 & 7.13 \\
\hline Total & 96.47 & 98.25 & 98.36 & 98.23 & 98.70 & 98.75 & 97.50 & 97.65 & 98.13 \\
\hline \multicolumn{10}{|l|}{ CIPW norms } \\
\hline Quartz & 5.90 & 0.00 & 0.61 & 0.00 & 0.00 & 0.00 & 5.41 & 11.58 & 12.58 \\
\hline Plagioclase & 28.56 & 66.91 & 67.75 & 62.62 & 58.83 & 68.46 & 27.91 & 30.87 & 31.20 \\
\hline Orthoclase & 30.16 & 5.84 & 7.10 & 2.44 & 3.12 & 0.76 & 40.26 & 30.77 & 32.21 \\
\hline Diopside & 2.33 & 13.95 & 18.65 & 17.08 & 21.56 & 13.17 & 6.09 & 6.08 & 6.37 \\
\hline Enstatite & 24.82 & 0.00 & 0.00 & 5.68 & 0.00 & 0.00 & 13.63 & 13.23 & 13.13 \\
\hline Olivine & 0.00 & 7.48 & 0.00 & 6.03 & 12.92 & 13.64 & 0.00 & 0.00 & 0.00 \\
\hline IImenite & 2.53 & 2.39 & 2.79 & 1.81 & 0.86 & 0.99 & 2.15 & 2.35 & 0.98 \\
\hline Magnetite & 3.27 & 2.79 & 1.22 & 3.97 & 2.55 & 2.83 & 2.47 & 2.87 & 2.14 \\
\hline Apatite & 2.43 & 0.64 & 1.89 & 0.37 & 0.15 & 0.15 & 2.07 & 2.24 & 1.37 \\
\hline Total & 100.00 & 100.00 & 100.00 & 100.00 & 100.00 & 100.00 & 100.00 & 100.00 & 100.00 \\
\hline \multicolumn{10}{|c|}{ Estimated Mineralogy } \\
\hline \multicolumn{10}{|c|}{ Quartz } \\
\hline \multicolumn{10}{|l|}{ Orthoclase } \\
\hline \multicolumn{10}{|l|}{ Plagioclase } \\
\hline \multicolumn{10}{|l|}{ Perthite } \\
\hline \multicolumn{10}{|l|}{ Biotite } \\
\hline \multicolumn{10}{|l|}{ Hornblende } \\
\hline \multicolumn{10}{|l|}{ Clinopyroxene } \\
\hline \multicolumn{10}{|l|}{ Orthopyroxene } \\
\hline \multicolumn{10}{|l|}{ Olivine } \\
\hline Spinel & & & & & & & & & \\
\hline Total & & & & & & & & & \\
\hline
\end{tabular}




\section{APPENDIX C: EXTEND METHODS: IMAGEJ AND TRAINABLE WEKA SEGMENTATION}

\section{FIJI AND TRAINABLE WEKA SEGMENTATION}

Fiji is one such bundled distribution of ImageJ and was constructed with the image processing needs of the scientific community in mind. Of particular importance for this project, the included plugin Trainable Weka Segmentation (TWS) serves as a means to quantitatively determine the mineral percentages of a rock through image segmentation and classification techniques. TWS uses a number of machine learning algorithms in combination with user defined image features to create a pixel by pixel segmentation and image classification which can then be used to determine mineral modes.

Similar outcomes can be attained using masking features in software such as Adobe Photoshop, however, TWS is superior to these methods in a number of ways:

1. TWS (along with ImageJ) is freely available under the GNU General Public License

2. Scripting capabilities using ImageJ's built-in macro language saves time when processing large numbers of images

3. User defined regions of interest are used to classify the image meaning every segmentation is related to a predetermined class

4. Multiple segmentation algorithms can be selected individually or in combination to achieve desired results

5. Accuracy of the classification can be scrutinised using the accompanying probability maps

\section{USING THE SOFTWARE}

After opening the desired image file in Fiji, it is necessary to crop the image to a representative area of the sample (Figure 1a). Cropping the image is necessary for two reasons, representativeness and minimization of memory usage. The image being supplied to the TWS plugin cannot contain pixels that do not represent the sample itself (ie image background). Cropping is also necessary to reduce the resolution of the image due to the memory intensive nature of the classification process. It is recommended that at least 16 gigabytes of RAM is installed in the computer before running a classification.

When a satisfactory crop has been attained, the TWS plugin can be opened via Plugins $>$ Segmentation $>$ Trainable Weka Segmentation (Figure 1b). Mineral classes can now be added to TWS and named accordingly using the Create New Class option. When the desired 
classes have been added, the user can then select Regions of Interest (ROI's) in the image that represent the various mineral classes (Figure 1c). The plugin evaluates the pixels within each ROI and uses this information to train the classification process. It is recommended to select approximately four to five ROI's for each mineral before running the classification. Special care should be taken to select regions that are truly representative of the desired mineral. This means avoiding grain boundaries and crystal imperfections where pixel values may differ significantly from the average.

When the classification is complete it can be evaluated for accuracy by comparing it to the original image. This can be done easily by selecting the 'toggle overlay' button on the plugin's side menu. Furthermore, the accuracy of the classification can be determined by assessing the probability maps associated with each mineral class (Figure 2). A greyscale map is produced for each mineral class in the classification where the brightness of each pixel represents the probability that that pixel belongs to the associated class. Dark colours represent pixels that have a low probability of belonging to the associated class while light colours have a high probability. Intermediate grey values suggest the classifier cannot confidently distinguish between two or more classes. 

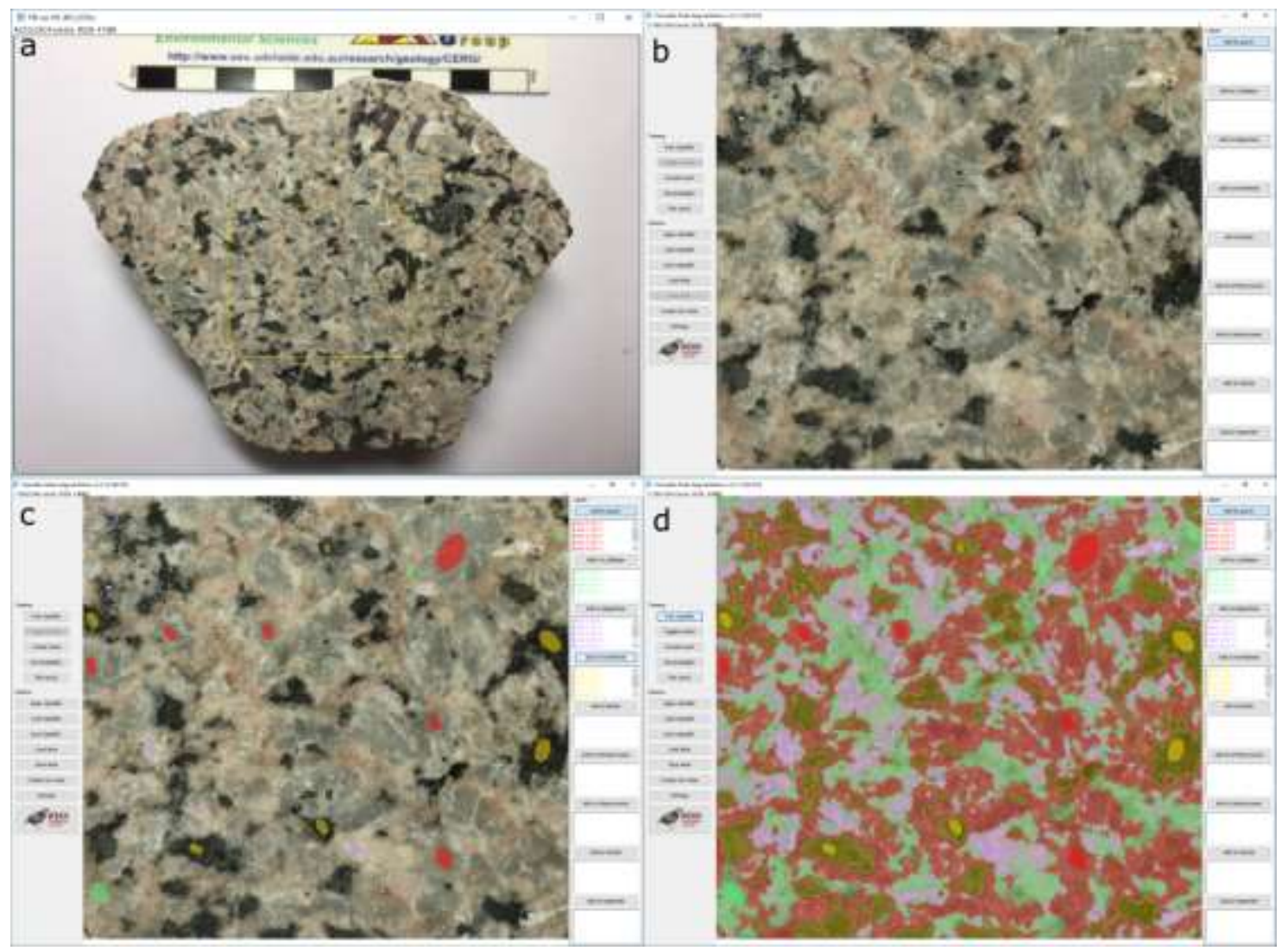

Figure 1 - Mineral classification using the Trainable Weka Segmentation plugin within Fiji. a - cropping the image, b - assigning a mineral to each class, $c$ selecting regions of interest, $d$ - the classified image.

For each class, a high degree of confidence can be had in the classification if the probability map appears more or less binary. With this in mind it can be seen in Figure 2 that hornblende (d) and plagioclase (c) have been classified reasonably well. On the other hand the probability maps for quartz (a) and $\mathrm{K}$ feldspar (b) suggest that there was some confusion during the classification process between these 
two minerals. When satisfied with the accuracy of the classification, the classified image can then be used to compute the mineral modes of the sample using image masking techniques. 


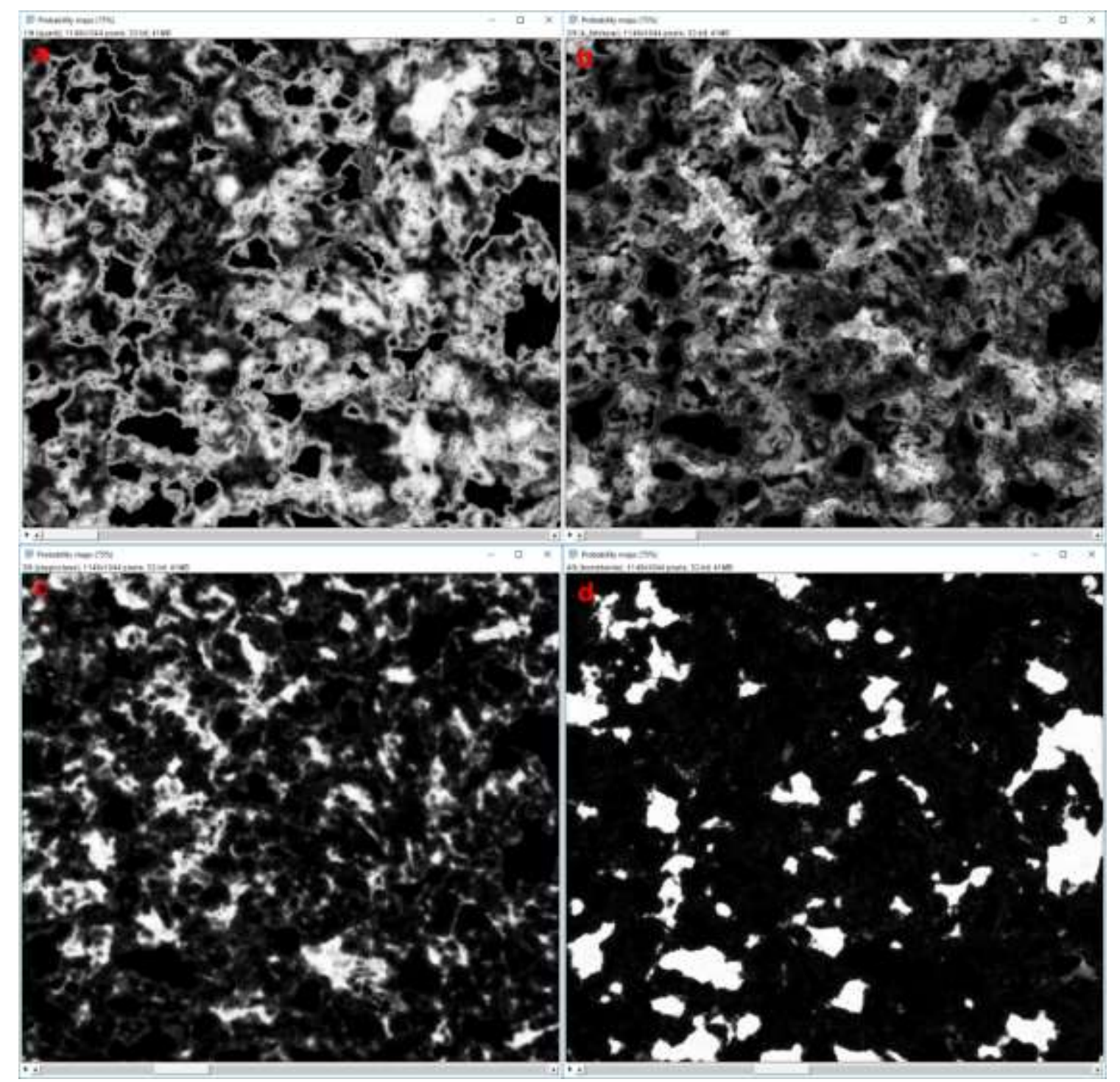


Figure 2 - Probability maps for each of the minerals during the classification. Light colours represent a high probability that the pixel belongs to the associated class. Dark colours represent a low probability that a pixel belongs to the associated class. Grey represents uncertainty in the pixel classification. (a - Quartz, b - K Feldspar, c - Plagioclase, d - Hornblende)

While user input is required in selecting the ROI's, much of the process can be automated using macros within the Fiji software. This can reduce the time taken for each sample down to less than five minutes depending on processor speeds. For a sample set of uniform characteristics, it may be possible to fully automate the entire process by using one classifier for many different images. This was not attempted in this project however due to the large variability in the samples being used. 